


\section{PROPOSIÇÃO E APLICAÇÃO DE UM PROCESSO DE AVALIAÇÃO DE SISTEMAS DE GESTÃO DA QUALIDADE ISO 9001:2000}

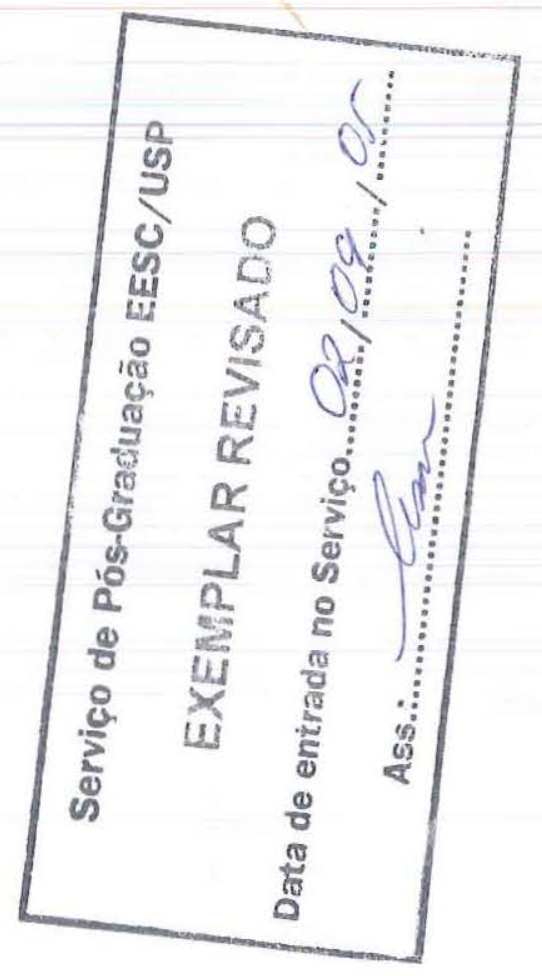

Dissertação apresentada à Escola de Engenharia de São Carlos da Universidade de São Paulo, como parte dos requisitos para a obtenção do Título de Mestre em Engenharia de Produção.

Orientador: Prof. Associado Luiz César Ribeiro Carpinetti

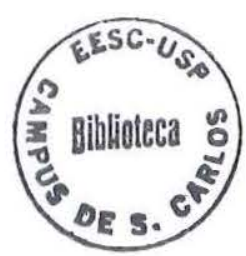

São Carlos

2005

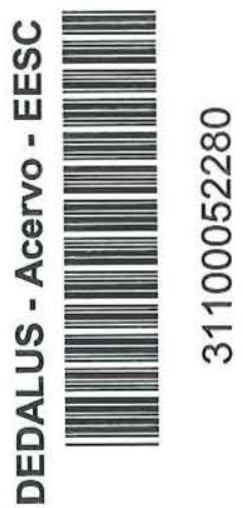




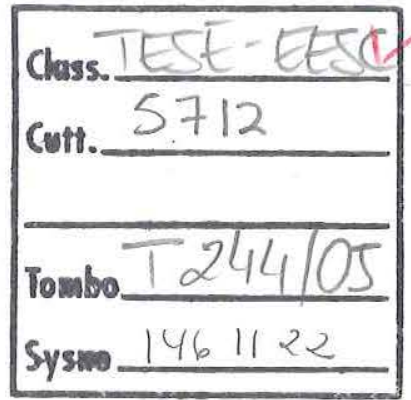

Ficha catalográfica preparada pela Seção de Tratamento da Informação do Serviço de Biblioteca - EESC/USP

Sordan, Juliano Endrigo

Proposição e aplicação de um processo de avaliação de sistemas de gestão da qualidade Iso 9001:2000 / Juliano Endrigo Sordan. -- São Carlos, 2005.

Dissertação (Mestrado) -- Escola de Engenharia de São Carlos-Universidade de São Paulo, 2005.

Área : Engenharia da Produção.

Orientador: Prof. Assoc. Luiz César Ribeiro Carpinetti.

1. ISSO 9000. 2. Auto-avaliação. 3. Sistemas de gestão da qualidade. I. Título. 
FOLHA DE JULGAMENTO

Candidato: Bacharel JULIANO ENDRIGO SORDAN

Dissertação defendida e julgada em 14-06-2005 perante a Comissão Julgadora:

\section{Prof. Associado LUIZ CESAR RIBEIRO CARPINETTI (Orientador)}

(Escola de Engenharia de São Carlos/USP)
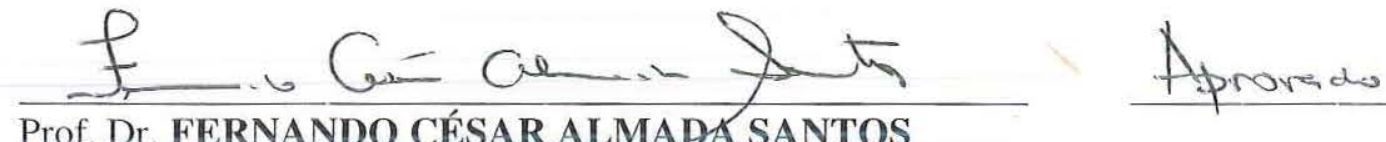

(Escola de Engenharia de São Carlos/USP)

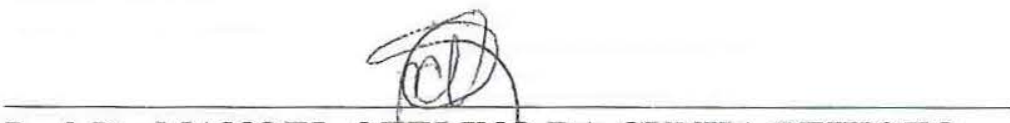

APROVADO

Prof. Dr. MANOEL OTELINO DA CUNHA PEIXOTO

(Universidade do Vale do Paraíba/UNIVAP)

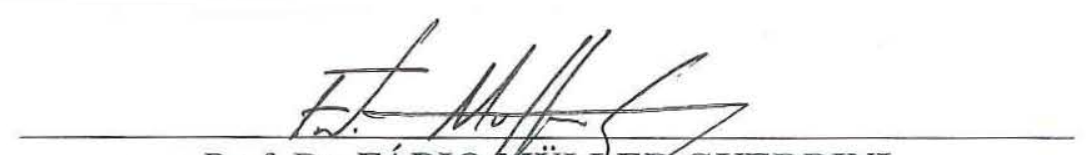

Prof. Dr. FÁBIO/MIÜLLER GUERRINI

Coordenador do Programa de Pós Graduação em Engenharia de Prơução

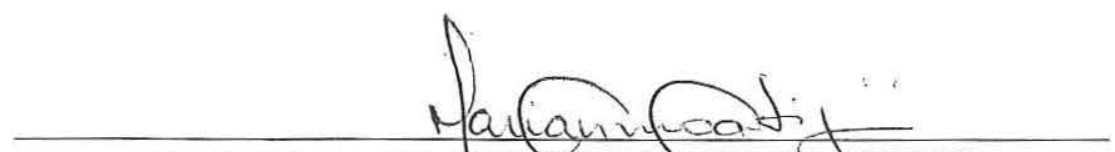

Profa. Titular MARIA DO CARMO CAUIJURI

Presidente da Comissão de Pós-Graduação 


\section{AGRADECIMENTOS}

Agradeço primeiramente a Deus, por ter me dado a capacidade, coragem e saúde para superar mais um desafio.

Ao prof. Luiz C. R. Carpinetti pela dedicada orientação, atenção e apoio durante todo o trabalho. Muito Obrigado.

Aos professores Edmundo Escrivão Filho e Fernando C. Almada Santos pelo apoio e incentivo.

Aos professores Antonio F. Rentes e Fábio Guerrini pelas reflexões e sugestões.

Ao Departamento de Engenharia de Produção da Escola de Engenharia de São Carlos EESC - USP. A todos os colaboradores da secretaria pelo suporte e atenção.

Aos colaboradores das organizações avaliadas que participaram deste trabalho, pela paciência e senso de colaboração. Ao pessoal da Santa Cruz S.A., em especial ao Mauricio K. Ometto e Gustavo H. Rodrigues pelo apoio.

Ao pessoal do Grupo de Pesquisa em Gestão da Melhoria e Mudança Empresarial GMME. Aos amigos Marcelo Rios, Michel L. Cerri, Álvaro Cabrera Jr., Fernanda Salles, Paulo R. Liba, Fabiano J. Lopes Alves, Edna A. Rodrigues e André Lucatto.

A toda a minha família pelo amor e incentivo. À Silvia pelo carinho, compreensão e apoio nos momentos difǐceis desta trajetória.

A todas as pessoas que contribuiram direta ou indiretamente para a concretização deste trabalho. 
"Caminante, son tus huellas el camino, y nada más: caminante, no hay camino, se hace camino al andar" 


\section{RESUMO}

SORDAN, J. E. (200. D. Proposição e aplicação de um processo de avaliação de sistemas de gestão da qualidade ISO 9001:2000. Dissertação (Mestrado) - Escola de Engenharia de São Carlos, Universidade de São Paulo, 2005.

O presente trabalho tem como objetivo a proposição e aplicação de um processo de avaliação de sistemas de gestão da qualidade segundo requisitos ISO 9001:2000. A avaliação da situação atual das práticas de gestão da qualidade de uma organização é uma condição indispensável para a certificação ISO 9001:2000. Muitas vezes, este processo implica altos custos relacionados a serviços de consultoria, que acabam sendo necessários devido à falta de conhecimento sobre os requisitos normativos por parte da organização, bem como a falta de um modelo simplificado de diagnóstico. Com base no processo proposto, infere-se que é possivel realizar uma avaliação das práticas de gestão da qualidade de uma organização de modo a identificar as lacunas entre essas práticas e os requisitos ISO 9001:2000. A dissertação é constituída pelas seguintes partes:

a) revisão de literatura, com o propósito de reforçar os conhecimentos concernentes à gestão da qualidade total e aos modelos de auto-avaliação; b) desenvolvimento do processo de avaliação a partir dos referenciais teóricos explorados; c) aplicação da proposta em organizações selecionadas; e d) avaliação dos resultados e conclusões sobre o trabalho. Infere-se que a aplicação da proposta será capaz de identificar as lacunas entre as práticas de gestão da qualidade e os requisitos ISO 9001:2000, além de permitir a identificação do estágio de adequação a esses requisitos. O processo de avaliação proposto também é capaz de identificar os pontos fortes e as oportunidades para melhoria, para que a organização possa se adequar aos requisitos ISO 9001:2000.

Palavras-chave: ISO 9000, auto-avaliação e sistemas de gestão da qualidade 


\section{ABSTRACT}

SORDAN, J. E. (2005). Proposition and application of an evaluation process for ISO 9001:2000 quality management systems. M.Sc. Dissertation - Escola de Engenharia de São Carlos, Universidade de São Paulo, São Carlos, 2005.

The present research aims the proposition and application of an assessment process for quality management systems according top the requirements ISO 9001:2000. The assessment of the current practices of quality management of an organization is an indispensable condition for the ISO 9001:2000 certification. Many times this application implies in elevated costs related to the consulting services, which are considered necessary due to the lack of knowledge about the requirements from the organizations as well as the absence of a simplified diagnosis model. Based on the proposed work, it is thought possible to perform an evaluation of the practices management of the quality of an organization so that it can identify the existent gaps between these practices and the ISO 9001:2000 requirements. The dissertation is constituted by two parts: a) a review of the literature with the proposal of reinforcing the knowledge related to the total quality management and to the self- assessment models; b) development of an assessment process from the explored theoretical references; c) the practical use of the proposed work in selected organizations and d) evaluation of the obtained results. It can be supposed that the application of the practical use of the work will allow the identification of the gaps between the current quality management practices and the requirements ISO 9001:2000, besides allowing the identification of the phase of adjustment to those requirements. The proposed evaluation process is also a useful tool for the identification of the strengths of the evaluated material and what needs to be improved so that the organization is able to adequate itself to ISO 9001:2000 requirements.

Keywords: ISO 9000; self-assessment; quality management systems 


\section{LISTA DE FIGURAS}

Figura 1- Desenvolvimento do trabalho............................................................ 5

Figura 2 - Principais etapas do trabalho e Capítulos associados............................. 8

Figura 3 - A TQM vista como uma extensão natural de abordagens anteriores Slack et al (1999) .................................................... 12

Figura 4 - Principais conceitos na recente história da qualidade - Bendell (2000)... 13

Figura 5 - Ciclo de uma panacéia - Gill e Whittle (1993) ........................................ 13

Figura 6 - Modelo de um sistema de gestão da qualidade baseado em processo

- International Organization for Standardization (2000).................. 18

Figura 7 - Estrutura de requisitos da ISO 9001:2000 - Carvalho (2002)................. 19

Figura 8 - Modelo sistêmico de áreas chave da ISO 9001:2000 - Tsim, Yeung e Leung (2002) ..................................................................................... 20

Figura 9 - Visão geral do processo de auditoria - International Organization for Standardization, NBR ISO 19011 (2002) .............. 21

Figura 10 - Estrutura Baldrige e Critérios para a Excelência do Desempenho -

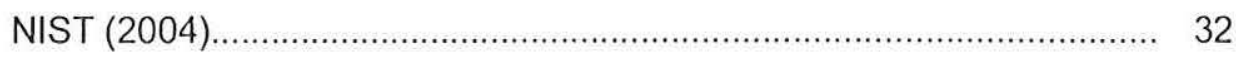

Figura 11 - Modelo de Excelência da EFQM - EFQM (2004) ............................... 33

Figura 12 - Modelo de Excelência do PNQ - FPNQ (2002) .................................. 36

Figura 13 - Diagrama de Gestão adaptados para os Primeiros Passos - FPNQ (2002) .......................................................................................... 40

Figura 14 - Correlação entre os Primeiros Passos e o PNQ - FPNQ (2002)........... 41

Figura 15 - Processo de gestão de um programa de avaliação................................ 44

Figura 16 - Atividades ligadas ao planejamento da avaliação................................ 45

Figura 17 - Atividades ligadas à análise da documentação..................................... 47

Figura 18 - Atividades ligadas à condução da avaliação....................................... 48

Figura 19 - Atividades ligadas à pontuação dos requisitos...................................... 49

Figura 20 - Atividades ligadas à apresentação dos resultados................................ 50 


\section{LISTA DE QUADROS}

Quadro 1 - Eventos importantes no desenvolvimento da gestão da qualidade total - adaptado de Martinez-Lorente, Dewhurst e Dale (1998)...

Quadro 2 - Os oito princípios de gestão da qualidade - adaptado de International Organization for Standardization (2004) ............................. 16

Quadro 3 - Série ISO 9000 - Adaptado de Stevenson e Barnes, 2002 ................... 17

Quadro 4 - Processo de certificação ISO 9000 - Stevenson e Barnes (2001)........ 27

Quadro 5 - Comparaçöes entre os principais prêmios da qualidade - adaptado de Ghobadian e Woo (1996)......

Quadro 6 - Correlação entre os critérios do PNQ e as diretrizes ISO 9004 adaptado de Nascimento e Alves (2001)......

Quadro 7 - Critérios, Itens e Pontuações Máximas - FPNQ (2002)......................... 39

Quadro 8 - Beneficios decorrentes da auto-avaliação - Ritchie e Dale (2000)......... 42

Quadro 9 - Seções, itens e pontuação máxima........................................................ 53

Quadro 10 - Escalas de alternativas................................................................ 54

Quadro 11 - Registro de evidências objetivas................................................... 55

Quadro 12 - Sintese da pontuação................................................................. 55

Quadro 13 - Faixas de pontuação.................................................................... 56

Quadro 14 - Requisitos Gerais (150 pontos)..................................................... 57

Quadro 15 - Requisitos de documentação (150 pontos) ........................................... 58

Quadro 16 - Comprometimento da direção, foco no cliente, politica da qualidade e planejamento (100 pontos) .......................................................... 59

Quadro 17 - Responsabilidade e autoridade, Representante da direção, Comunicação interna e Análise Critica pela Direção (100 pontos).......

Quadro 18 - Provisão de recursos, Infra-estrutura e ambiente de trabalho (75

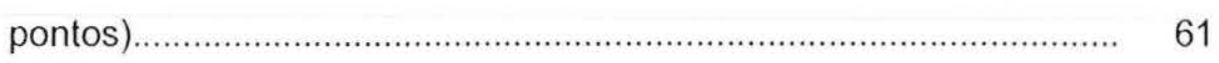

Quadro 19 - Recursos humanos (75 pontos) ...................................................... 62

Quadro 20 - Planejamento da realização do produto e processos relacionados a clientes (45 pontos) ........................................................................... 63

Quadro 21 - Projeto e desenvolvimento (20 pontos)............................................... 64

Quadro 22 - Aquisição e controle de dispositivos de medição e monitoramento (

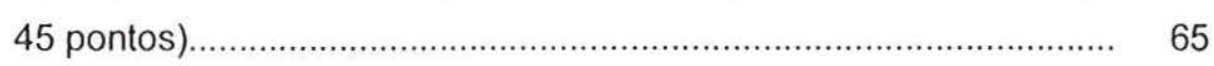

Quadro 23 - Realização do produto (40 pontos)................................................... 66

Quadro 24 - Medição e monitoramento (100 pontos)................................................ 67

Quadro 25 - Controle de produto não-conforme, análise de dados e melhorias ( 100 pontos) 
Quadro 26 - Síntese de pontuação obtida pela "empresa A" 73

Quadro 27 - Sintese de pontuação obtida pela "empresa B". 78

Quadro 28 - Síntese de pontuação obtida pela "empresa C" 82

Quadro 29 - Síntese de pontuação obtida pela "empresa D" 86

Quadro 30 - Síntese de pontuação obtida pela "empresa E" 91

Quadro 31 - Faixas de pontuação das empresas avaliadas. 94 
SUMÁRIO

RESUMO

ABSTRACT

1. INTRODUÇÃO

1.1 Contextualização do problema de pesquisa ..........................................................

1.2 Objetivos do trabalho ................................................................................. 4

1.3 Desenvolvimento do trabalho ....................................................................... 4

1.4 Estrutura do trabalho ..................................................................................

2. GERENCIAMENTO DA QUALIDADE ….................................................... 9

2.1 A evolução do movimento da qualidade ......................................................... 9

2.2 Normas ISO 9000 - sistemas de gestão da qualidade..................................... 14

2.2.1 Considerações gerais ................................................................................ 14

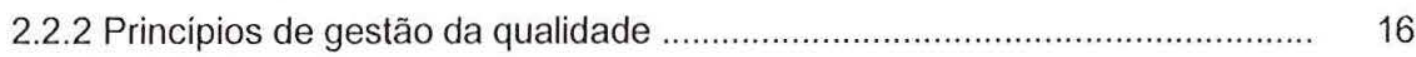

2.2.3 A estrutura ISO 9000 .................................................................................... 17

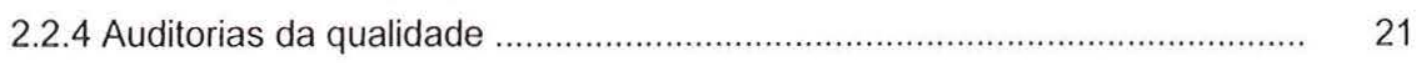

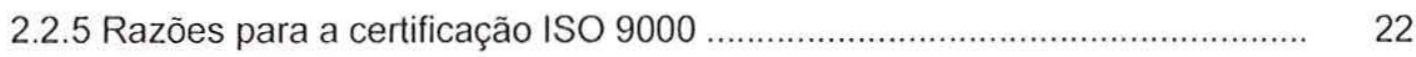

2.2.6 Principais criticas .................................................................................... 23

2.2.7 Beneficios decorrentes da certificação ……............................................... 25

2.2.8 O processo de certificação ........................................................................ 27

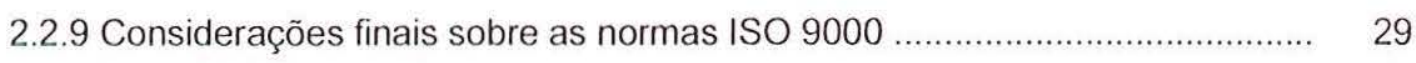

2.3 Modelos de excelência .................................................................................. 29

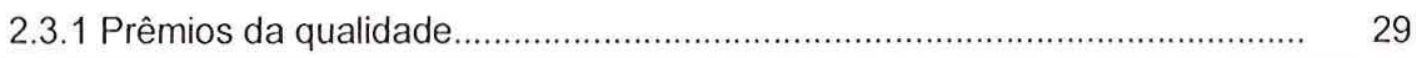

2.3.2 O Prêmio Deming....................................................................................... 30

2.3.3 O Prêmio Malcolm Baldrige ....................................................................... 32

2.3.4 O Prêmio Europeu da Qualidade - EFQM.................................................. 33

2.3.5 Comparações entre os prêmios da qualidade e a ISO 9000.......................... 34

2.3.6 O Prêmio Nacional da Qualidade - PNQ ....................................................... 35

2.3.6.1 Os Primeiros Passos para a Excelência ...................................................... 38

2.3.7 Considerações finais sobre os modelos de excelência .................................. 41

3. PROPOSTA PARA AVALIAÇÃO DA ADEQUAÇÃO AOS REQUISITOS ISO

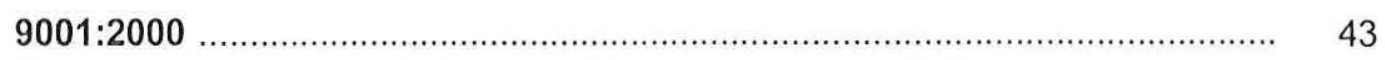

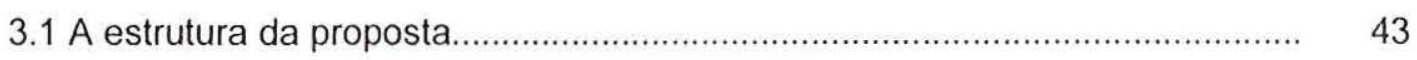


3.1.1 Passo 1 - Planejamento da avaliação............................................................. 44

3.1.2 Passo 2 - Análise da documentação ............................................................. 46

3.1.3 Passo 3 - Verificação in loco....................................................................... 48

3.1.4 Passo 4 - Pontuação dos requisitos................................................................. 49

3.1.5 Passo 5 - Apresentação dos resultados.................................................... 50

3.2 Instrumento avaliatório................................................................................... 51

3.2.1 Diretrizes para pontuação ……………….................................................. 53

3.3 Apresentação dos itens de avaliação..................................................... 57

3.3.1. Sistema de gestão da qualidade............................................................ 57

3.3.1.1 Requisitos gerais.......................................................................... 57

3.3.1.2 Requisitos de documentação................................................................... 58

3.3.2 Responsabilidade da direção.................................................................... 59

3.3.2.1 Comprometimento da direção, foco no cliente, política da qualidade e planejamento.

3.3.2.2 Responsabilidade e autoridade, representante da direção, comunicação interna e análise critica pela direção............................................................. 60

3.3.3 Gestão de recursos...................................................................................... 61

3.3.3.1 Provisão de recursos, infra-estrutura e ambiente de trabalho..................... 61

3.3.3.2 Recursos humanos................................................................................... 62

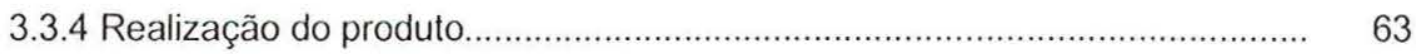

3.3.4.1 Planejamento da realização do produto e processos relacionados a

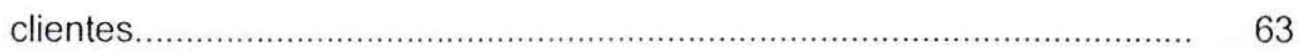

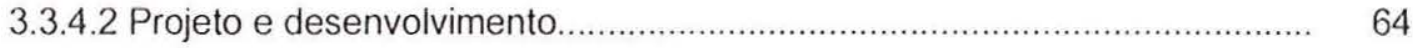

3.3.4.3 Aquisição e controle de dispositivos de medição e monitoramento............ 65

3.3.4.4 Realização do produto.......................................................................... 66

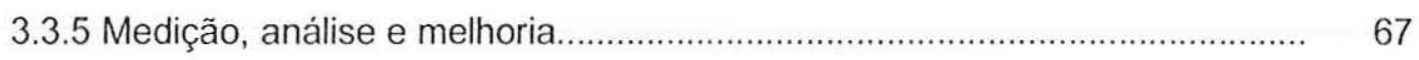

3.3.5.1 Medição e monitoramento........................................................................ 67

3.3.5.2 Controle de produto não-conforme, análise de dados e melhorias............. 68

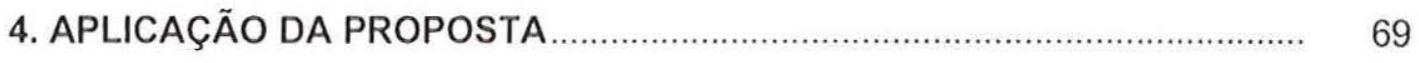

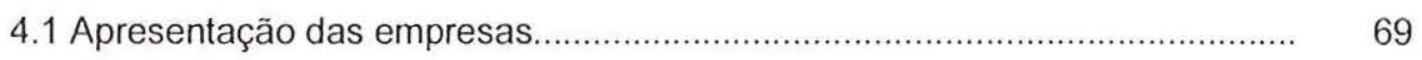

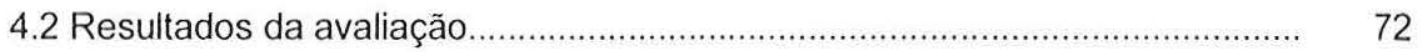

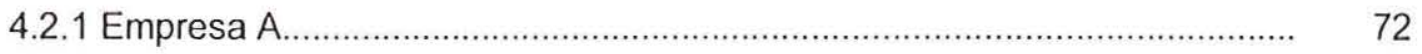

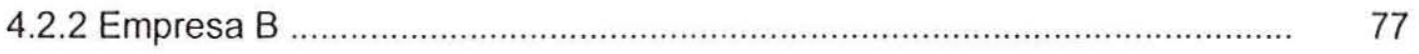

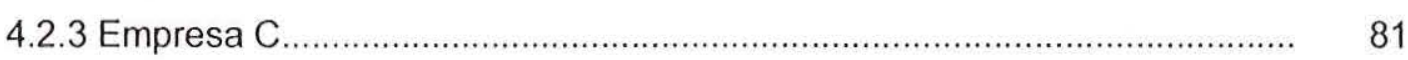

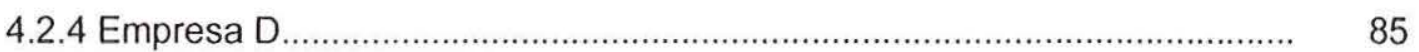


4.2.5 Empresa $\mathrm{E}$ 90

4.3 Resultados Globais

5 CONCLUSÕES.

96

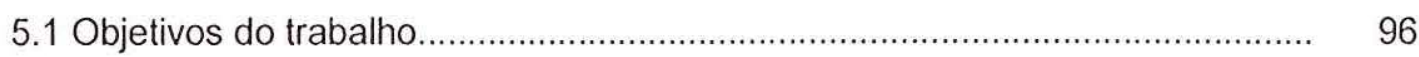

5.2 Desenvolvimento da proposta........................................................................... 97

5.3 Constatações decorrentes da aplicação......................................................... 97

5.4 Limitações acerca da proposta..................................................................... 98

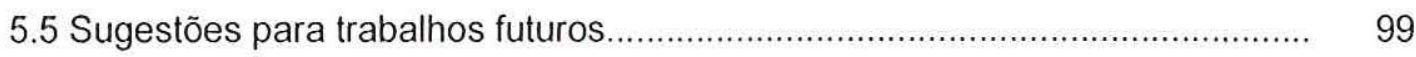

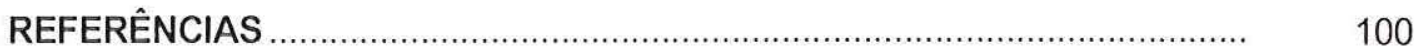




\section{INTRODUÇÃO}

Neste item apresenta-se a contextualização e a problemática da pesquisa através de uma linha de raciocínio apoiada em referências bibliográficas, com o objetivo de justificar e esclarecer a proposição do trabalho. Apresenta-se também, a definição dos objetivos, o desenvolvimento do trabalho e a estrutura do trabalho proposto.

\subsection{Contextualização do Problema de Pesquisa}

Com o advento da globalização, a busca pela competitividade tornotrse uma estratégia presente em muitas organizações. A ampla gama de produtos e serviços ofertados, a exigència crescente do mercado consumidor e o desenvolvimento tecnológico, entre outros fatores corroboram a necessidade de reformulação das estratégias organizacionais com o propósito de alcançar vantagem competitiva. Nesta conjuntura, a organização que relegar a qualidade, independente de seu porte ou ramo de atividade, encontrará grandes obstáculos para manter-se no mercado.

Para Davenport e Prusak (1999), as organizações não devem esperar que as práticas e produtos que garantiram seu sucesso no passado possam assegurar sua sobrevivência no futuro, visto que, hoje, as empresas necessitam de fatores como: bom atendimento, valor, inovação, velocidade de chegada ao mercado e qualidade.

Os Sistemas de Gestão da Qualidade baseados nos requisitos ISO 9000 ganharam relevância no àmbito comercial pelo fato de atenderem as necessidades básicas no que se refere à qualidade dos produtos e serviços. Desde a sua publicação, os requisitos ISO 9000 tornaram-se almejados por inúmeras organizações. Com isso, as normas internacionais ISO 9000 vêm sendo adotadas por vários países, permitindo o estabelecimento de requisitos-chave para a gestão da qualidade e viabilizando a relação comercial entre as organizações, independente de seu porte, sua nacionalidade ou seu ramo de atividade. 
A credibilidade e popularidade dos padrões ISO 9000 permitiu a difusão do conceito de sistemas de gestão da qualidade em todo o mundo. No ambiente empresarial, as diversas empresas de consultoria passaram a oferecer "pacotes" ou serviços de implementação e manutenção de sistemas de gestão da qualidade nos moldes dos padrões ISO 9000. No âmbito acadêmico, a criação de periódicos específicos, bem como a publicação de inúmeros trabalhos, vêm enriquecendo a discussão acerca do tema.

Wood Júnior e Urdan (1994) declaram que as normas ISO 9000 por si só não garantem qualidade superior ou competitividade, mas podem ser extremamente úteis, quando utilizadas como um guia para a implantação de sistemas de gestão da qualidade. Embora existam muitas críticas relacionadas a esses padrões, organizações que necessitem de um mínimo de estruturação podem benefíciar-se com a implantação dos requisitos. Além disso, a questão essencial parece ser a exigência de sua adoção pelos clientes, o que respalda a importância da certificação ISO 9000 para a sobrevivência organizacional.

Uma pesquisa realizada pela International Organization for Standardization (2002) revela que em dezembro de 2002, cerca de 561.747 certificados ISO 9000 foram emitidos em 159 paises caracterizando um aumento de 51.131 certificados emitidos $(10,02 \%)$ em relaçào ao mesmo período no ano anterior. Segundo dados do INMETRO (2004), 9.672 certificados ISO 9000 foram emitidos no Brasil até o ano de 2004. Deste total, 4.090 certificados (42.29\%) foram emitidos na nova versão ISO 9001:2000.

Este crescimento evidencia a importància da certificação ISO 9000 para as organizações brasileiras, que cada vez mais direcionam consideráveis esforços para o alinhamento de suas práticas aos padrões ISO 9000. Entretanto, ao buscar uma certificação, uma empresa poderá encontrar algumas dificuldades no que diz respeito à interpretação e ao diagnóstico da situação atual.

Embora os padrões ISO 9000 não prescrevam qualquer tipo de prática específica, o processo de certificação exige um certo grau de conhecimento quanto à interpretação e implantação dos requisitos. Conforme estabelece a International Organization for Standardization (2000), todos os requisitos: "são genéricos e se pretende que sejam aplicáveis a todas as organizações, sem levar em consideração o tipo, tamanho e produto fornecido". 
Ott (1997) afirma que as normas ISO 9000 são genéricas para os sistemas de gestão da qualidade e a implementação de seus requisitos pode variar de acordo com o ambiente no qual a organização está inserida. Assim, a linguagem genérica dos padrões dificulta a associação de tais requisitos a uma organização particular. Na visão do autor, essa associação é extremamente importante para avaliar o status atual da organização em relação aos padrões, para articular as exigências desses padrões e também para planejar uma implementação efetiva e eficaz do sistema.

Para conseguir a certificação, as organizações precisam tomar uma série de ações de modo a adequar suas práticas de gestão da qualidade aos requisitos normativos. Antes de submeter-se à auditoria de certificação é preciso um diagnóstico que permita a identificação das lacunas entre o sistema de gestão da qualidade da organização e os requisitos ISO 9000. Entretanto, para realizar este diagnóstico, as empresas acabam tendo que contratar serviços de consultoria, devido à falta de compreensão dos requisitos normativos, bem como de um método simplificado de avaliação para a identificação destas lacunas.

Na visão de Tavares Júnior (2001), dentre as vantagens de uma avaliação podemos citar o levantamento detalhado dos pontos fortes e fracos, os quais permitem à organização adquirir informações relevantes para o planejamento e a programação de melhorias com melhor qualidade.

Muitas críticas em relação às normas ISO 9000 denunciam as dificuldades encontradas pelas organizações que iniciaram o processo de certificação. Uma delas em especial refere-se aos custos da certificação ISO 9000. Segundo Stevenson e Barnes (2001), há quatro fatores que geram custos durante o processo de certificação: tempo, treinamento, consultorias e a certificação em si mesma.

O tempo necessário para a certificação pode variar de menos de um ano para mais de dois anos (geralmente em torno de dezoito meses). Isto depende de muitos fatores, como por exemplo, o tamanho e a complexidade da organização, os padrões atuais de qualidade, a extensão da atual documentação e o nível de comprometimento da alta administração. Para conduzir este processo, organizações acabam contratando consultores para assegurar a passagem pela auditoria ISO (STEVENSON e BARNES, 2001). 
A escassez de estudos relacionados à avaliação da adequação aos requisitos ISO 9000 também respalda a importância de se desenvolver um trabalho com esse enfoque. Segundo Ritchie e Dale (2000), há uma quantidade limitada de estudos empíricos sobre processos de auto-avaliação no que diz respeito a sua realização objetivando uma identificaçào de diferentes niveis de maturidade da gestão da qualidade da organização.

Com base nas considerações apresentadas surge a questão da pesquisa do trabalho: como avaliar a adequação das práticas atuais de gestão da qualidade de uma organização em relação aos requisitos ISO 9000, através de um processo simplificado e capaz de identificar os pontos fortes e oportunidades para melhoria?

\subsection{Objetivos do Trabalho}

O objetivo principal deste trabalho consiste na proposição e aplicação de um processo para a avaliação das práticas de gestão da qualidade de uma organização, em relação aos requisitos normativos ISO 9001:2000.

Faz parte desta proposição:

O desenvolvimento de um processo de avaliação baseado no modelo de gestão de um programa de auditoria e capaz de identificar os pontos fortes e as oportunidades para melhoria do sistema de gestão da qualidade da organização;

A elaboração de um instrumento simplificado para a avaliação das práticas de gestão da qualidade em relação aos requisitos ISO 9000, bem como do estágio de aderência a estes requisitos.

Ainda faz parte do objetivo deste trabalho, o desenvolvimento de algumas aplicações em empresas certificadas e não-certificadas, instaladas na região.

\subsection{Desenvolvimento do trabalho}

A primeira parte deste trabalho tem como objetivo reforçar os conhecimentos concernentes à gestão da qualidade, especialmente no que tange as normas ISO 9000 e a metodologia de auto-avaliação da Fundação para o Prêmio Nacional da Qualidade (2002) "Primeiros Passos para a Excelência: Critérios para o bom desempenho e diagnóstico da organização". A revisão bibliográfica é realizada através de periódicos especializados, anais de congressos nacionais, livros, dissertações, teses e Internet adotando como palavras-chave: ISO 9000. auto-avaliação e sistemas de gestão da qualidade. 
A segunda parte consiste no desenvolvimento da proposta a partir dos referenciais teóricos explorados na revisão da literatura e na aplicação prática em organizações certificadas ou que almejam a certificação ISO 9001:2000 e que estão instaladas na região. O desenvolvimento e a aplicação da proposta visa oferecer uma resposta à questão de pesquisa apresentada anteriormente.

Para a avaliação da proposta, faz-se necessário a sua aplicação em algumas organizações certificadas e não-certificadas na norma ISO 9001:2000. Desse modo, a terceira parte deste trabalho compreende a aplicação do método em cinco organizações instaladas na região.

Os resultados obtidos durante a aplicação do método nas empresas selecionadas permitirão a análise da proposta deste trabalho, bem como a apresentação das conclusões e sugestões para trabalhos futuros.

A Figura 1 ilustra o desenvolvimento do trabalho proposto.

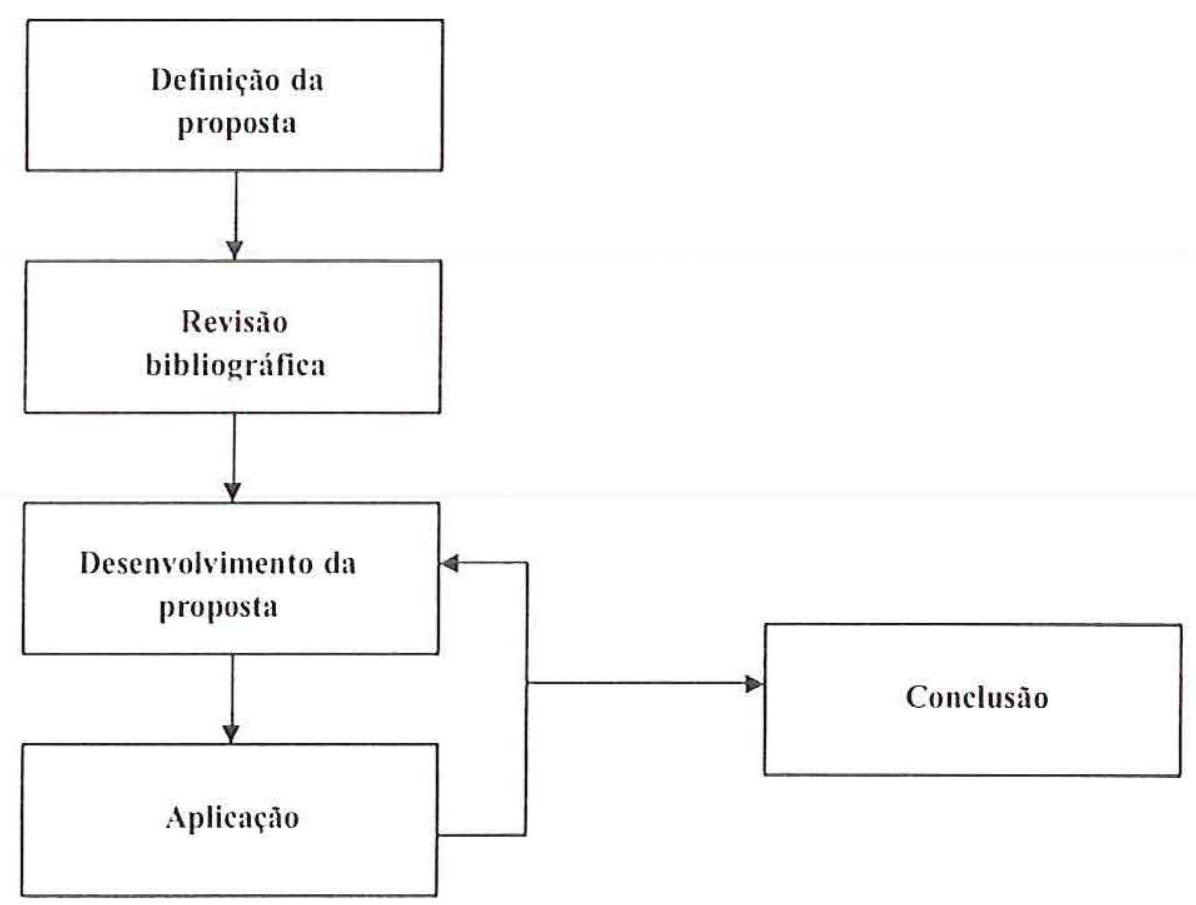

Figura 1 - Desenvolvimento do trabalho 
Para que a aplicação da proposta seja eficaz, o pesquisador deverá participar de forma empírica na condução do trabalho, além de propiciar o envolvimento dos colaboradores das organizaçòes envolvidas. Com isso, a pesquisa caracteriza-se como pesquisa-ação. Segundo Thiollent (2000), a pesquisa-ação pode ser definida como:

Um tipo de pesquisa social com base empírica que é concebida e realizada em estreita associação com uma ação ou com a resoluçào de um problema coletivo e no qual os pesquisadores e os participantes representativos da situaçào ou do problema estão envolvidos de modo cooperativo ou participativo (THIOLLENT, 2000).

Para Roesch (1999), neste tipo de pesquisa o pesquisador pode ser caracterizado como um consultor, um orientador ou um colaborador. Segundo a autora, na pesquisaação:

a suposição é de que se pode aprender, a partir do conteúdo, sobre processos e resultados da intervenção, sobre o que é possivel e o que não é possivel, sobre o que funciona e o que nào funciona, exatamente porque este é o modo como os fatos acontecem e as pessoas agem numa situaçào particular (ROESCH, 1999).

Thiollent (2000) apresenta seis aspectos sobre a pesquisa-ação:

1. A interação entre o pesquisador e as pessoas implicadas na situação investigada;

2. A ordem de prioridade dos problemas a serem pesquisados, bem como das soluções a serem tomadas resulta da interação entre o pesquisador e as pessoas envolvidas;

3. O objeto de investigação é constituido pela situação social e pelos problemas de diversas naturezas, e não pelas pessoas;

4. O objetivo da pesquisa-açào consiste na resolução ou esclarecimento dos problemas encontrados;

5. Durante o processo há um acompanhamento das decisões, das ações e de todas as atividades relacionadas com as pessoas envolvidas;

6. A pesquisa-ação permite o aumento do conhecimento das pessoas e grupos relacionados. 


\subsection{Estrutura do Trabalho}

O presente trabalho encontra-se dividido em cinco capítulos. O Capítulo 1 descreve a contextualização do problema de pesquisa, os objetivos, o desenvolvimento e a estrutura do trabalho.

O Capítulo 2 apresenta uma revisão sobre os principais conceitos acerca do tema central deste trabalho. Desta forma, é feita uma revisão sobre a evolução do movimento da qualidade, o desenvolvimento de sistemas de gestão da qualidade nos moldes da ISO 9000, bem como os modelos de excelência que deram origem às práticas de auto-avaliação.

O Capítulo 3 apresenta de forma detalhada as fases do método de pesquisa e a arquitetura da proposta.

O Capítulo 4 relata a aplicação da proposta em cinco organizações avaliadas, descrevendo suas características e os resultados da avaliação, incluindo os pontos fortes e as oportunidades para melhoria e a pontuação global obtida em cada organização.

O trabalho é concluído com o Capítulo 5, apresentando os benefícios e limitações práticas da proposta, bem como sugestòes para trabalhos futuros.

A Figura 2 apresenta as principais etapas do trabalho e os Capitulos associados. 
Definição do problema: como avaliar as práticas de gestão da qualidade de uma organização em relaçào aos requisitos ISO 9000 ?
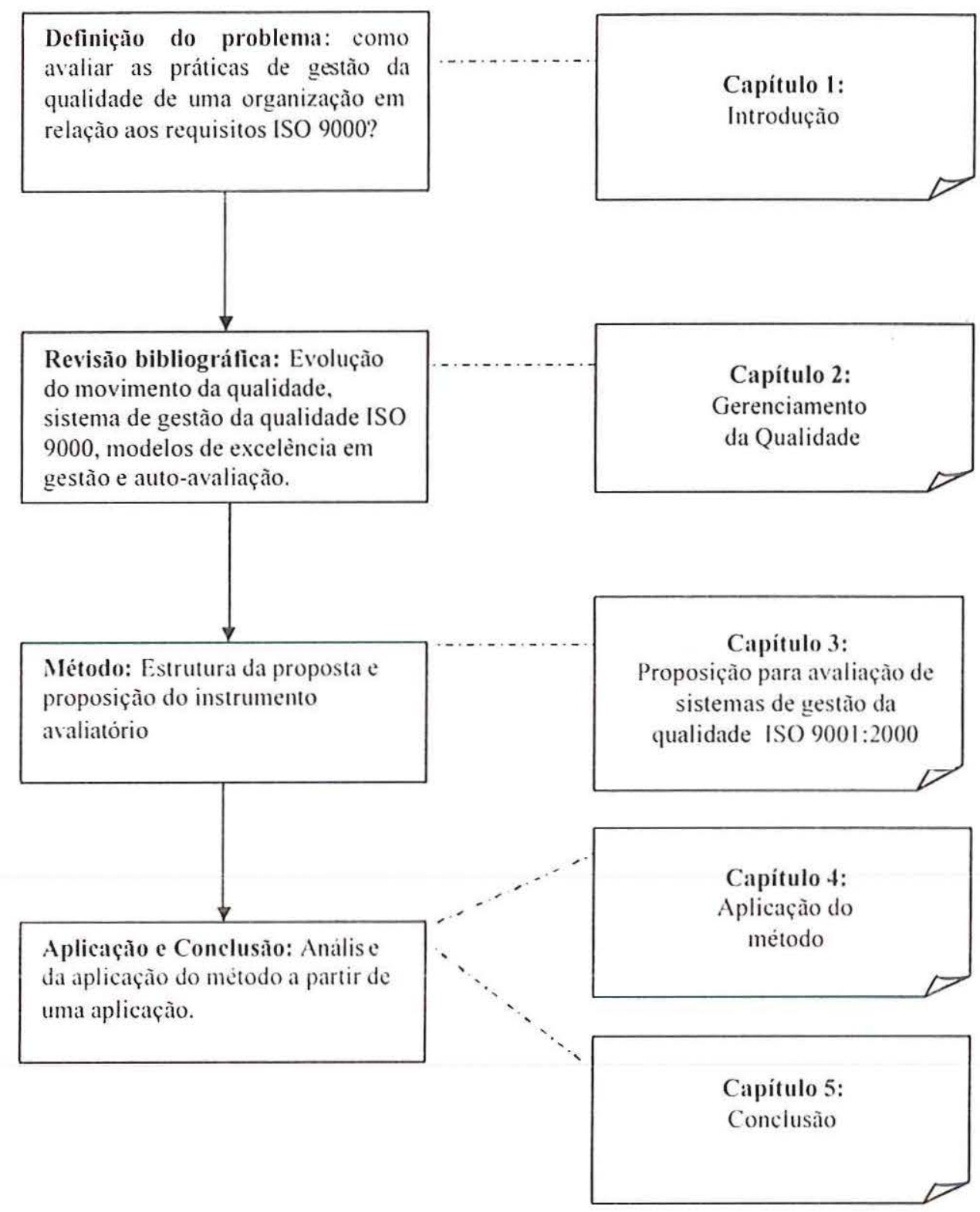

Figura 2 - Principais etapas do trabalho e capítulos associados 


\section{GERENCIAMENTO DA QUALIDADE}

Neste Capítulo apresenta-se uma revisão bibliográfica acerca dos principais conceitos que nortearão a construção teórica do trabalho. No item 2.1, apresenta-se a contextualização da evolução do movimento da qualidade. Nos itens 2.2 e 2.3, apresenta-se as bases metodológicas e teóricas (Normas ISO 9000 e Primeiros Passos FPNQ) que darão suporte para a construção do método proposto.

\subsection{A evolução do movimento da qualidade}

A preocupação com a qualidade não é uma caracteristica exclusiva do pensamento organizacional contemporâneo. Esta preocupação pode ser evidenciada por antigas civilizações, como por exemplo, a procura de métodos para obter melhores colheitas às margens do Nilo, bem como os detalhes que caracterizaram as edificações na antiga Roma. (RODRIGUES, 1999).

No periodo que antecedeu a Revolução Industrial, a qualidade era sinônimo de perfeição técnica. A inspeção era uma atividade informal, realizada após o produto pronto. Com o advento da produção em massa no início do século XX e o surgimento da Administração Científica, as atividades de inspeção passaram a envolver a segregação dos produtos defeituosos antes de serem encaminhados para o consumidor. A partir da década de 50 , os principais gurus da qualidade introduziram o conceito de Qualidade Total, que inicialmente foi difundido no Japão e posteriormente envolveu a indústria Ocidental (FAESARELLA, SACOMANO e CARPINETTI, 2003).

Segundo Bendell (2000), a Primeira Guerra Mundial estimulou a necessidade de produção em massa e conseqüentemente, o aumento da inspeção. Isto proporcionou o desenvolvimento do conceito de amostragem e gráficos de controle. Com o advento da Segunda Guerra Mundial, houve um rápido desenvolvimento de técnicas estatísticas para a medição, avaliação e controle da qualidade. Nesse contexto, surge o conceito de garant ia da qualidade culminando no desenvolvimento das normas ISO 9000. 
Garvin (1992) considera que a evolução do movimento da qualidade na indústria norte-americana pode ser organizada em quatro "eras da qualidade". Para o autor, "em sua versão original, a qualidade era responsabilidade do departamento de produção; hoje, saiu da fábrica e entrou na sala da alta gerència". Nesse sentido, a qualidade, antes direcionada para as atividades de inspeção passou a ser considerada como elemento fundamental para o desempenho estratégico.

O conceito de produção sem defeitos tornotrse insuficiente para garantir o comprometimento da alta gerência, preocupada com a concorrência e com a estratégia. A solução foi definir qualidade do ponto de vista do cliente, fazendo com que a alta direção das empresas expressasse interesse pela qualidade, incluindo-a no processo de planejamento estratégico como uma arma agressiva de concorrência. Assim, a preocupação das empresas passou a ser a melhoria contínua com a adoção de programas voltados à obtenção de comprometimento de toda a organização para com a qualidade. (GARVIN, 1992).

A entrada de produtos japoneses no mercado americano na década de 70 , bem como o impacto das obras de Crosby, Deming, Feigenbaum e Juran deram origem ao desenvolvimento da gestão qualidade nos Estados Unidos. Os trabalhos destes autores, além de outros como Ishikawa foram estudados por organizações e universidades que integraram estes conceitos com a gestão da qualidade dando origem ao conceito de TQM (MARTÍNEZ-LORENTE, DEWHURST e DALE, 1998). O Quadro 1 apresenta alguns eventos importantes no desenvolvimento da Gestão da Qualidade Total.

Para Brocka e Brocka (1994), a Gestão da Qualidade Total ou TQM (Total Quality . Management) tem como objetivo melhorar continuamente a produtividade em todos os níveis de uma organização, com o apoio dos recursos financeiros e humanos disponiveis. De acordo com os autores, o gerenciamento da qualidade:

Constitui-se em uma fílosofia e em uma série de princípios que representam os fundamentos de uma melhoria contínua sobre a organização, sobre todos os seus processos e em uma medida das necessidades dos clientes. (BROCKA e BROCKA, 1994).

Segundo Toledo (1997), a Gestão da Qualidade Total está associada a um estágio de incorporação da qualidade na estratégia das organizações representando uma visão de como gerenciar os negócios com foco na satisfação total do cliente. Além disso, a Gestão da Qualidade Total é constituída por princípios, veículos promocionais, ferramentas e metodologias. 
Faesarella, Sacomano e Carpinetti (2003) reconhecem TQM como "um sistema ou conjunto de atividades cujo objetivo é identificar e administrar as atividades necessárias para a maximização da competitividade de uma empresa". Na visão dos autores, esta maximização decorre da melhoria contínua da qualidade dos produtos, serviços, processos, recursos humanos e redução de custos. A Gestão da Qualidade Total se fundamenta em alguns princípios, tais como: satisfação do cliente; compromisso da alta direçào; desenvolvimento de pessoas; gestão participativa e por processos; garantia da qualidade e aperfeiçoamento contínuo de produtos e processos; aplicação de metodologias científicas e disseminação e padronização da informação.

Quadro 1: Eventos importantes no desenvolvimento da gestão da qualidade total.

\begin{tabular}{|c|c|}
\hline 1924-1932 & $\begin{array}{l}\text { As experièncias em Hawthome demonstraram a importância do clima psicológico e } \\
\text { social no trabalho. }\end{array}$ \\
\hline 1924 & Shewhart desenvolveu o controle estatistico de processo. \\
\hline 1926 & Bell Telefone implantou o método de controle estatístico. \\
\hline $1940-1950$ & $\begin{array}{l}\text { O exército americano adotou o uso de métodos de amostragem durante a segunda guerra } \\
\text { mundial. }\end{array}$ \\
\hline 1950 & Primeira visita de Deming ao Japào. \\
\hline 1951 & Criação do "Deming tpplication Prize" no Japào. \\
\hline 1954 & $\begin{array}{l}\text { Primeira edição de "Quality Control Handhook" de Juran. } \\
\text { Primeira visita de Juran ao Japão. } \\
\text { Teoria de Maslow sobre necessidades humana. }\end{array}$ \\
\hline 1960 & $\begin{array}{l}\text { Japào enfatiza a melhoria da qualidade para a competitividade. } \\
\text { Teoria } X \text { e Y de McGregor. }\end{array}$ \\
\hline 1961 & Primeira ediçào do livro "Total Quality Control" de Feigenbaum. \\
\hline 1962 & $\begin{array}{l}\text { A idéia de circulos da qualidade apareceu no final de uma edição da revista japonesa } \\
\text { "Quality Control for the Foreman". }\end{array}$ \\
\hline 1972 & QFD foi desenvolvido na Mitsubishi. \\
\hline 1973 & $\begin{array}{l}\text { Após a crise do petróleo em } 1973 \text { os sistemas JIT foram adotados por inúmeras } \\
\text { organizaçōes americanas e curopéias. }\end{array}$ \\
\hline 1970-1980 & Círculos da qualidade foram introduzidos nos Estados Unidos. \\
\hline 1979 & $\begin{array}{l}\text { Primeira ediçào do livro "Quality is free" de Crosbi. } \\
\text { A Xerox adotou o conceito de benchmarking nos processos. } \\
\text { Publicaçào da norma de gestão da qualidade BS } 5750 .\end{array}$ \\
\hline 1980 & $\begin{array}{l}\text { O documentário da NBC sobre o "milagre japonès" apresentou Deming como elemento- } \\
\text { chave deste fenòmeno. }\end{array}$ \\
\hline 1981 & Teoria Z de Ouchi. \\
\hline 1982 & Primeira edição do livro "Qualitỵ. Productivity and Competitive Position" de Deming. \\
\hline 1983 & $\begin{array}{l}\text { O artigo "Quality on the line" de Garvin, publicado na Harvard Business Review, } \\
\text { analisou as diferenças entre as organizaços japonesas e americanas. } \\
\text { Um texto sobre experimento de projeto, de Taguchi foi publicado na Harvard Business } \\
\text { Review. }\end{array}$ \\
\hline 1986 & Primeira edição do livro "Out of the Crisis" de Deming, o qual se tornou um bestseller. \\
\hline 1987 & Primeira edição da norma ISO 9000. \\
\hline 1987 & Publicaçào do Prêmio Nacional da Qualidade Malcolm Baldrige. \\
\hline
\end{tabular}

Fonte: Adaptado de Martinez-Lorente, Dewhurst e Dale (1998). 
Na visão de Slack et al. (1997), TQM pode ser compreendida como uma fílosofia voltada ao atendimento das necessidades e expectativas dos clientes envolvendo todas as pessoas de uma organização. Assim, "TQM pode ser vista como uma extensão lógica da maneira em que a prática da qualidade tem progredido". A Figura 3 ilustra os enfoques pertinentes a cada prática.

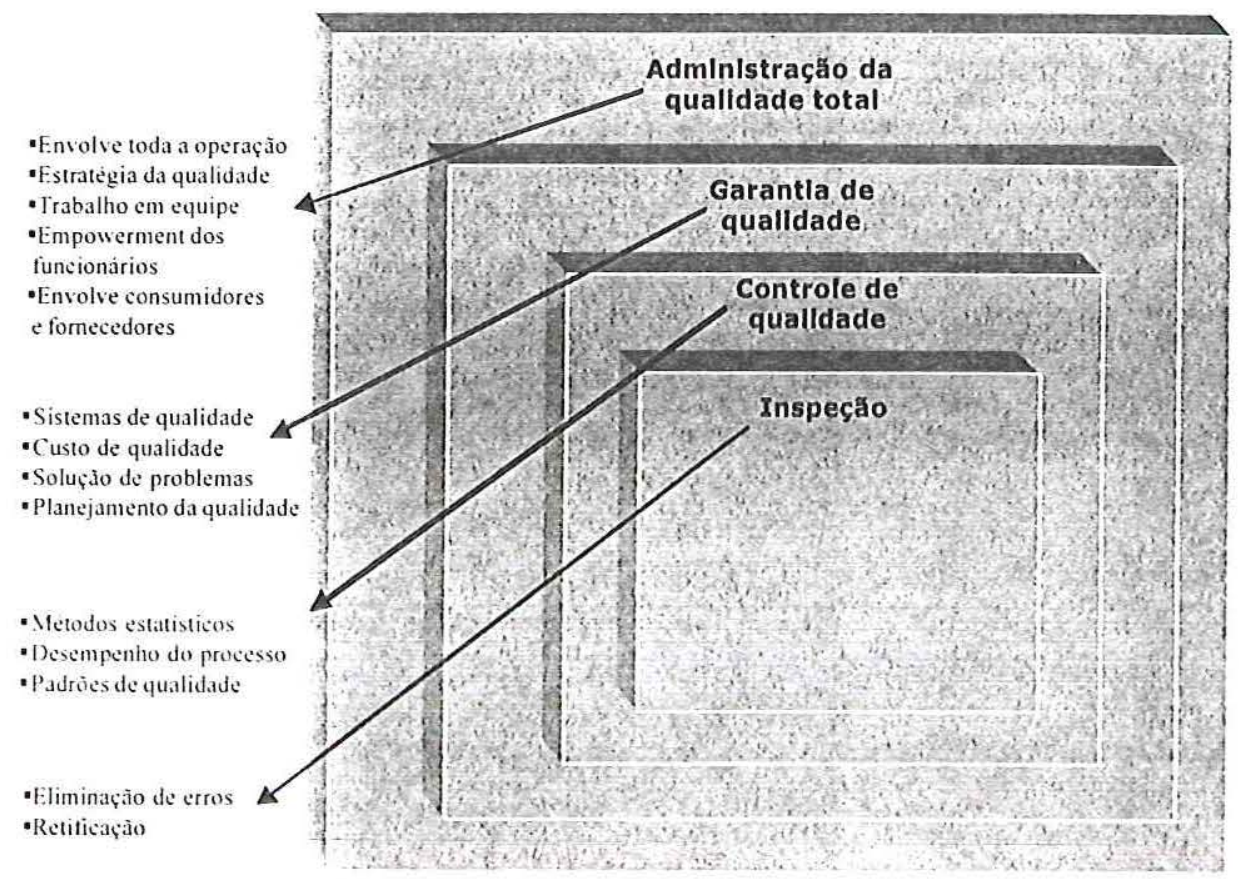

Figura 3 - A TQM vista como uma extensão natural de abordagens anteriores

(Slack et al., 1997)

Garvin (1992) considera que a gestão estratégica da qualidade é uma extensão de suas antecessoras e não uma negação delas. Contudo, a nova abordagem é mais ampla do que as anteriores, envolvendo aspectos como: lucratividade, objetivos, foco no cliente e melhoria contínua. Esse enfoque ampliou as responsabilidades, inicialmente atribuidas ao departamento de produção, para toda a empresa, desde o chão-de-fábrica até a alta gerência, tornando a qualidade uma função gerencial. 
O conceito de qualidade na década de 80 e 90 apresentou uma grande diversidade de definações, usos e importância. A mesma terminologia foi utilizada por áreas, publicações e conceitos diferentes refletindo e resultando em um matestar geral no movimento da qualidade. (BENDELL, 2000). A Figura 4 ilustra um esquema do desenvolvimento histórico dos principais conceitos acerca da qualidade.

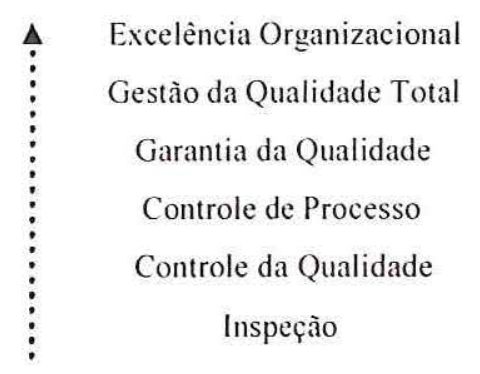

Figura 4 - Principais conceitos na recente história da qualidade (Bendell, 2000).

Nas últimas décadas têm-se notado uma grande variedade de "produtos" e conceitos relacionados à gestão da qualidade. Muitas metodologias e práticas de gestão da qualidade foram desenvolvidas com o objetivo de auxiliar as empresas a melhorar sua competitividade. Assim, organizações têm adotado algum tipo de fílosofia ou iniciativa para obter resultados direcionados ao controle e gestão da qualidade, como por exemplo, Total Quality Management (TQM), Just-in-Time (JIT), Prêmios da Qualidade e ISO 9000 (MAGD e CURRY, 2003).

Gill e Whittle (1993) reconhecem estas iniciativas como panacéias destinadas ao aumento da efícácia organizacional e são caracterizadas como fenômenos culturais e psicodinâmicos. Segundo os autores, estas iniciativas têm um ciclo de vida no qual inicia-se com o entusiasmo da adoção em larga escala até o esgotamento e abandono. A Figura 5 ilustra o ciclo de uma panacéia.

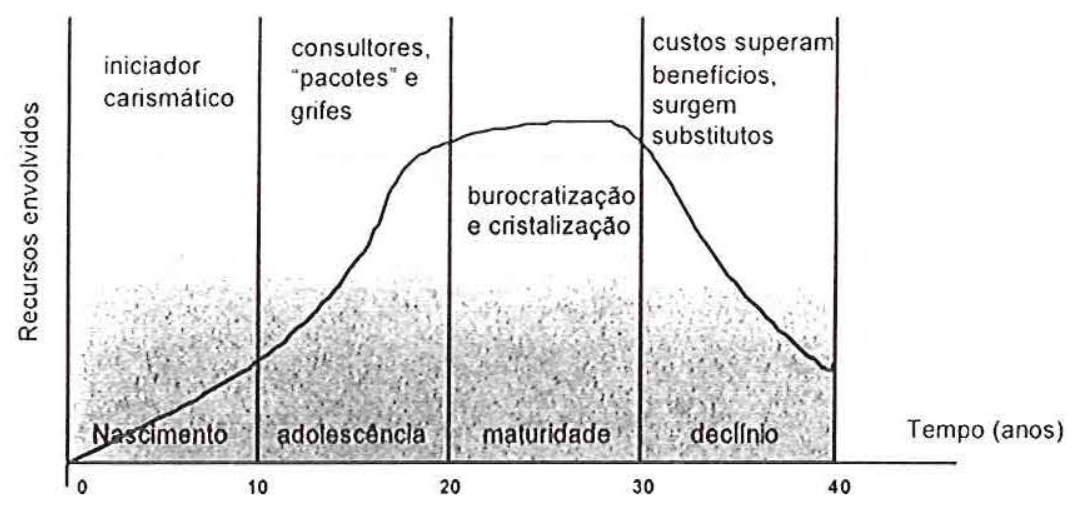

Figura 5 - Ciclo de uma panacéia (Gill e Whittle, 1993). 
Muitas vezes, práticas como programas de organização e limpeza, controle estatístico de processo, metodologia para análise e solução de problemas, análise de falhas e sistemas de gestão da qualidade, entre outros, acabam sendo vistos pela comunidade empresarial de forma pejorativa, por não corresponderem a curto-prazo às expectativas da organização. É preciso compreender que tais iniciativas não representam "soluçòes universais", e sim, metodologias e ferramentas decorrentes da evolução do movimento da qualidade e que hoje fazem parte do Gerenciamento da Qualidade.

\subsection{Normas ISO 9000 - sistema de gestão da Qualidade}

\subsubsection{Considerações gerais}

Desde o seu surgimento em 1987, as normas ISO 9000 têm sido adotadas como referência ou padrão nacional para sistemas de gestão da qualidade em diversos paises e regiões, como forma de assegurar aos clientes que os produtos e serviços adquiridos satisfazem seus requisitos (PUN, CHIN e LAU, 1999). Para Dick (2000), o aumento progressivo da utilizaçào das normas ISO 9000 sugere que a certificação tem sido encarada como um fator importante para a posição competitiva de organizações de manufatura e serviços.

Com a eliminação das barreiras comerciais no mercado europeu, os padrões ISO 9000 tornaram-se uma marca registrada permitindo aos fabricantes demonstrarem seus reconhecidos sistemas de qualidade para seus clientes internacionais. Muitas empresas inseridas neste mercado passaram a estabelecer seus próprios sistemas de qualidade, de acordo com os requisitos normativos ISO 9000 criando desta forma, um clima favorável à qualidade e despertando o interesse e a atenção de pessoas em todo o mundo (YUNG, 1997).

Para Mello et al. (2002), as normas de sistema de gestão proporcionam um modelo a ser seguido pela organização com o objetivo de preparar e operar o seu sistema de gestão. Por sistema de gestão, pode-se entender como tudo aquilo que a organização realiza para gerenciar seus processos e atividades. Esse modelo reúne as principais características que especialistas da área reconhecem como o estado da arte. 
A International Organization for Standardization (ISO), foi fundada na Europa em 1947 com o propósito de facilitar as relações comerciais entre vários paises, através do desenvolvimento de padrões internacionais de qualidade para produtos e serviços. (STEVENSON e BARNES, 2001). A partir de 1987 iniciourse a criação de normas internacionais de qualidade. Esse conjunto de normas, reconhecido como série ISO 9000 apresentava um conjunto de recomendações para a implementação de sistemas de gestão da qualidade de produtos e serviços (FAESARELLA, SACOMANO e CARPINETTI, 2003).

Considerando que não há nenhuma exigência legal direta para a adoção das normas ISO 9000, estas normas caracterizam-se como normas voluntárias. Entretanto, esses padrões podem ser compulsórios, à medida que se caracterizarem como exigências dos clientes. A ISO 9000 é aplicada para o gerenciamento de sistemas da qualidade, porém, quando houver normas aplicáveis à produção, é inconcebível que se possa atingir a ISO $9000 \mathrm{sem}$ o atendimento das normas apropriadas para o produto, processo, ou segurança. Outra consideração importante a respeito da ISO 9000, é a sua capacidade de satisfazer um número significativo de exigências estratégicas e corporativas levando em consideração o mercado, aspectos legais e de produtividade, assim como as mudanças nas relações cliente-fornecedor. (ROTHERY, 1993).

De acordo com Rothery (1993), o primeiro conjunto de normas ISO 9000 descrevia estas normas como "refinamento de todos os princípios mais práticos e usualmente aplicáveis dos sistemas da qualidade" e "a culminação do acordo entre as autoridades mundiais mais avançadas dessas normas com base em uma nova era para o gerenciamento da qualidade". Essa primeira versão foi baseada na norma britânica BS 5750, com algumas pequenas mudanças. 


\subsubsection{Os princípios de gestão da qualidade}

As normas da série ISO 9000:2000 estão baseadas em oito princípios de gestão da qualidade que podem ser adotados como referencial para guiar a melhoria do desempenho organizacional. Esses principios foram estabelecidos pelo comitê técnico ISO/TC 176 (responsável pelo desenvolvimento e manutenção das mrmas ISO 9000) e estão definidos nas normas ISO 9000:2000 e ISO 9004:2000. O Quadro 2 descreve os princípios e apresenta os seus principais benefícios

Quadro 2 - Os oito princípios de gestão da qualidade

Puincílio
1. Foco no cliente
As organizaçoses dependem de seus clientes e, portanto,
devem compreender suas necessidades atuais e futuras,
devem atender aos seus requisitos e procurar exceder às
suas expectativas.
2. Liderança

Lideres estabelecem a unidade de propósito e o rumo da organização. Eles devem criar e manter um ambiente interno, no qual as pessoas possam se envolver totalmente no alcance dos objetivos da organização.

\section{Envolvimento de pessoas}

Pessoas de todos os niveis são a essència de uma organizaçào e seu total envolvimento permite que as suas habilidades sejam usadas para o benefĩcio da organização.

4. Abordagem do processo

Um resultado desejado é alcançado mais eficientemente quando as atividades e os recursos relacionados são gerenciados como um processo.

5. Abordagem sistêmica para a gestão

Identificar, compreender e gerenciar os processos interrelacionados como um sistema contribui para a eficiència e eficácia da organizaçào no alcance dos seus objetivos.

\section{Melhoria Contínua}

A melhoria continua do desempenho global da organizaçào deve ser um objetivo permanente da organizaçào.

\section{Abordagem factual para tomada de decisões} Decisões eficazes são baseadas na análise de dados e informaçòes.

\section{Benefícios mútuos nas relações com fornecedores} Uma organização e seus fornecedores são interdependentes e uma relação mutuamente benéfica aumenta a capacidade de ambos agregar valor.
Princjuais Bchefícios

- Aumento nos lucros;

- Posição de mercado;

- Efetividade;

- Aumento da lealdade e satisfação dos clientes.

- Maior compreensào dos objetivos;

- Motivação das pessoas;

- Melhoria da comunicaçào;

- Aumento da confiança:

- Eliminação do medo.

- Maior confiança das pessoas;

- Inovação e criatividade;

- Aumento da responsabilidade:

- Comprometimento com a melhoria continua.

- Redução de custos;

- Redução do tempo de ciclo;

- Oportunidades de melhoria;

- Identificação das atividades que geram valor às partes interessadas.

- Integração e alinhamento dos processos;

- Compreensiào das interdependèncias dos principais processos;

- Medição e avaliação do sistema.

- Melhoria do desempenho;

- Flexibilidade para reagir rapidamente às oportunidades;

- Capacitação em métodos e ferramentas de melhoria;

- Informaçōes para a tomada de decisào;

- Acessibilidade de dados;

- Análise de dados e informações através de métodos válidos;

- Criação de valor para ambas as partes;

- Otimização de custos e recursos;

- Comunicação clara e aberta;

- Flexibilidade e velocidade.

Fonte: Adaptado de International Organization for Standardization (2004). 


\subsubsection{A estrutura ISO 9000}

As atuais normas da série ISO 9000 foram revisadas e simplificadas no ano de 2000. Antes dessa revisão havia três normas para certificação. A ISO 9001 representava a norma mais abrangente envolvendo pesquisa, projeto, desenvolvimento, produção, serviços associados e instalação. A ISO 9002 foi menos abrangente, pois rão cobria os processos de projeto e desenvolvimento. A ISO 9003 servia para organizações que desempenhavam atividades como inspeções e testes (STEVENSON E BARNES, 2002).

Em 2002 surgiu a norma ISO 19011 com o propósito de fornecer diretrizes sobre a realização de auditorias do sistema de gestão da qualidade e também de auditorias de sistema de gestão ambiental. O Quadro 3 ilustra a aplicabilidade das principais normas que compõem a série ISO 9000.

Quadro 3 - Série ISO 9000

\begin{tabular}{|c|c|}
\hline Norma & Foco \\
\hline \multicolumn{2}{|l|}{ Versão 1994} \\
\hline ISO 9000 & Norma de garantia e gestão da qualidade para seleçào e uso \\
\hline ISO 9001 & $\begin{array}{l}\text { Modelo de sistema de qualidade para garantir a qualidade em } \\
\text { organizações que incluem processos de projeto, desenvolvimento, } \\
\text { produção, instalação e serviços associados }\end{array}$ \\
\hline ISO 9002 & $\begin{array}{l}\text { Modelo de sistema de qualidade para garantir a qualidade em } \\
\text { organizações que incluem produção, instalação e serviços associados }\end{array}$ \\
\hline ISO 9003 & $\begin{array}{l}\text { Modelo de sistema de qualidade para garantia da qualidade em inspeção e } \\
\text { ensaios finais }\end{array}$ \\
\hline ISO 9004 & Diretrizes e elementos para o sistema da qualidade e gestão da qualidade \\
\hline ISO 10011 & Diretrizes para auditoria de sistemas da qualidade \\
\hline \multicolumn{2}{|l|}{ Versão 2000} \\
\hline ISO 9000:2000 & $\begin{array}{l}\text { Sistema de gestão da qualidade - fundamentos e vocabulários. Define } \\
\text { nommas e terminologia }\end{array}$ \\
\hline ISO 9001:2000 & $\begin{array}{l}\text { Sistema de gestão da qualidade - requisitos. Uso para avaliação da } \\
\text { adequação com os requisitos (consolidação das normas ISO } \\
9001 / 9002 / 9003 \text { da versão anterior dentro de um único documento) }\end{array}$ \\
\hline ISO $9004: 2000$ & $\begin{array}{l}\text { Sistema de gestão da qualidade - diretrizes para melhoria do } \\
\text { desempenho. Guia para a melhoria continua do sistema de gestão da } \\
\text { qualidade. }\end{array}$ \\
\hline ISO 19011:2002 & $\begin{array}{l}\text { Diretrizes para auditorias de sistema de gestão da qualidade e/ou } \\
\text { ambiental. Diretrizes para a realização de auditorias do sistema de gestão } \\
\text { da qualidade. }\end{array}$ \\
\hline
\end{tabular}

Fonte: Adaptado de Stevenson e Barnes (2002). 
As normas da série ISO 9000 passam por revisões periódicas a cada cinco anos, de modo que seus requisitos sejam coerentes com a realidade vivenciada pelas organizações. A terceira versão da norma foi publicada em 2000 levando em consideração aspectos importantes para o desempenho organizacional, incluindo o foco no cliente, a abordagem por processos e a melhoria contínua. Os termos empregados foram simplificados permitindo uma leitura mais amigável ao usuário e os requisitos tornaram-se compativeis com outras normas, como por exemplo, a ISO 14000.

Bendell (2000) esclarece que os vinte requisitos que constituíam a norma ISO 9000, versão 1994, foram substituídos nas normas ISO 9001:2000 e ISO 9004:2000 por uma nova estrutura baseada em processos. Na nova versão, os requisitos foram agrupados em cinco capítulos:

sistema de gestão da qualidade;

$>$ responsabilidade da alta direção;

$>$ gestão de recursos;

$>$ realização do produto;

$>$ medição, análise e melhoria.

A Figura 6 ilustra o modelo de um sistema de gestão da qualidade baseado em processos e a inter-relação entre seus elementos.

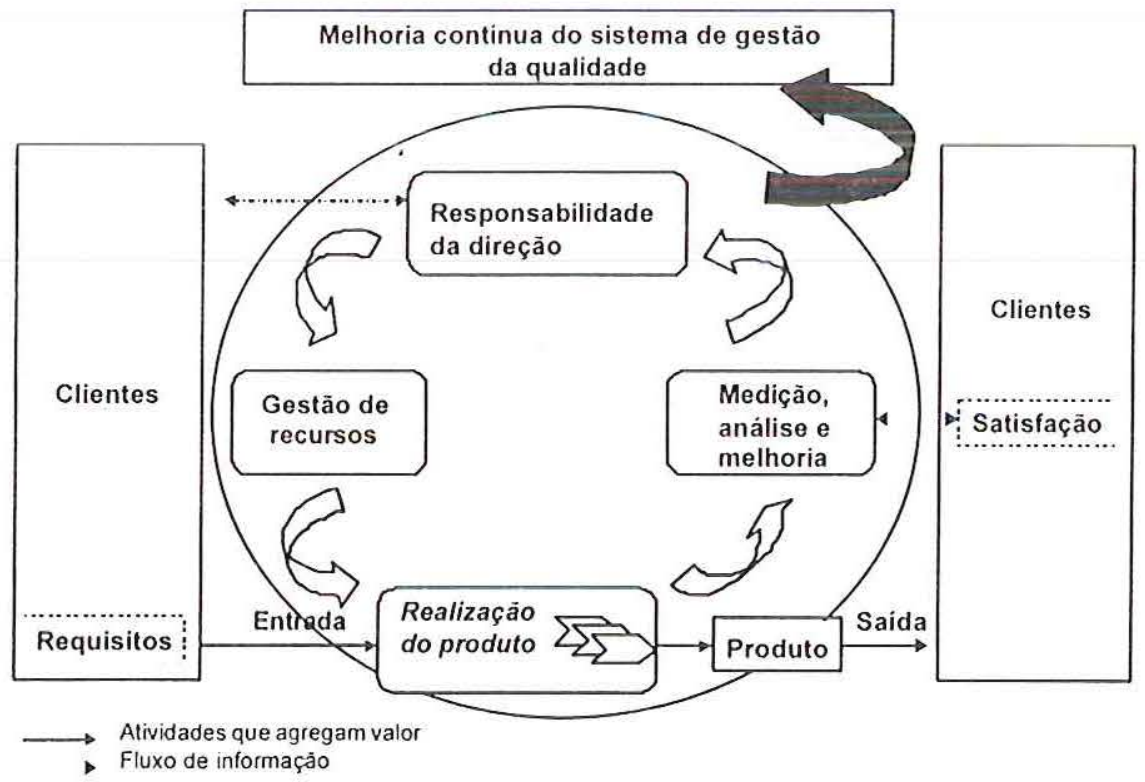

Figura 6 - Modelo de um sistema de gestão da qualidade baseado em processo (ISO, 2000). 
Carvalho (2002) apresenta um modelo no qual a estrutura da ISO 9001:2000 se baseia em processo, ou seja, aplica-se a um escopo de processos que devem ser determinados pela organização e que são necessários para atender às necessidades do cliente de modo a assegurar sua satisfação. Esse modelo lastreia-se num conjunto de oito principios os quais são análogos aos principios de norteiam os prèmios nacionais da qualidade, incluindo o Prêmio Nacional da Qualidade - PNQ. A Figura 7 ilustra a estrutura da norma ISO 9001:2000 baseada em processos.

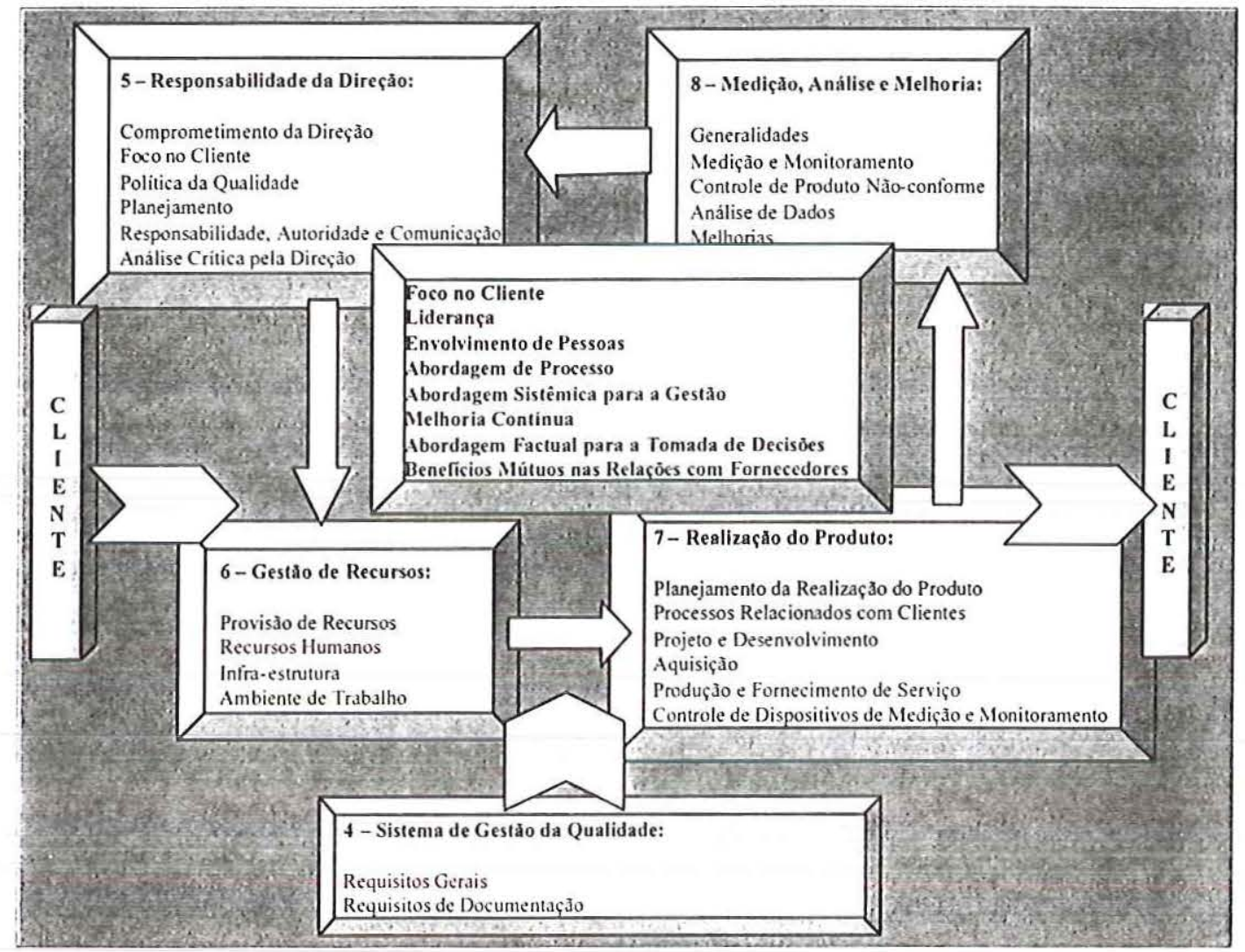

Figura 7 - Estrutura de requisios da ISO 9001:2000 (Carvalho, 2002).

Tsim, Yeung e Leung (2002) reconhecem quatro áreas-chave para a adaptação da ISO 9001:2000. Essas áreas são denominadas atividades gerenciais, gestão focada em processos, satisfação do cliente e melhoria contínua. Para ilustrar a integração dessas áreas-chave e seus conceitos básicos os autores apresentam um modelo sistêmico, conforme Figura 8. 


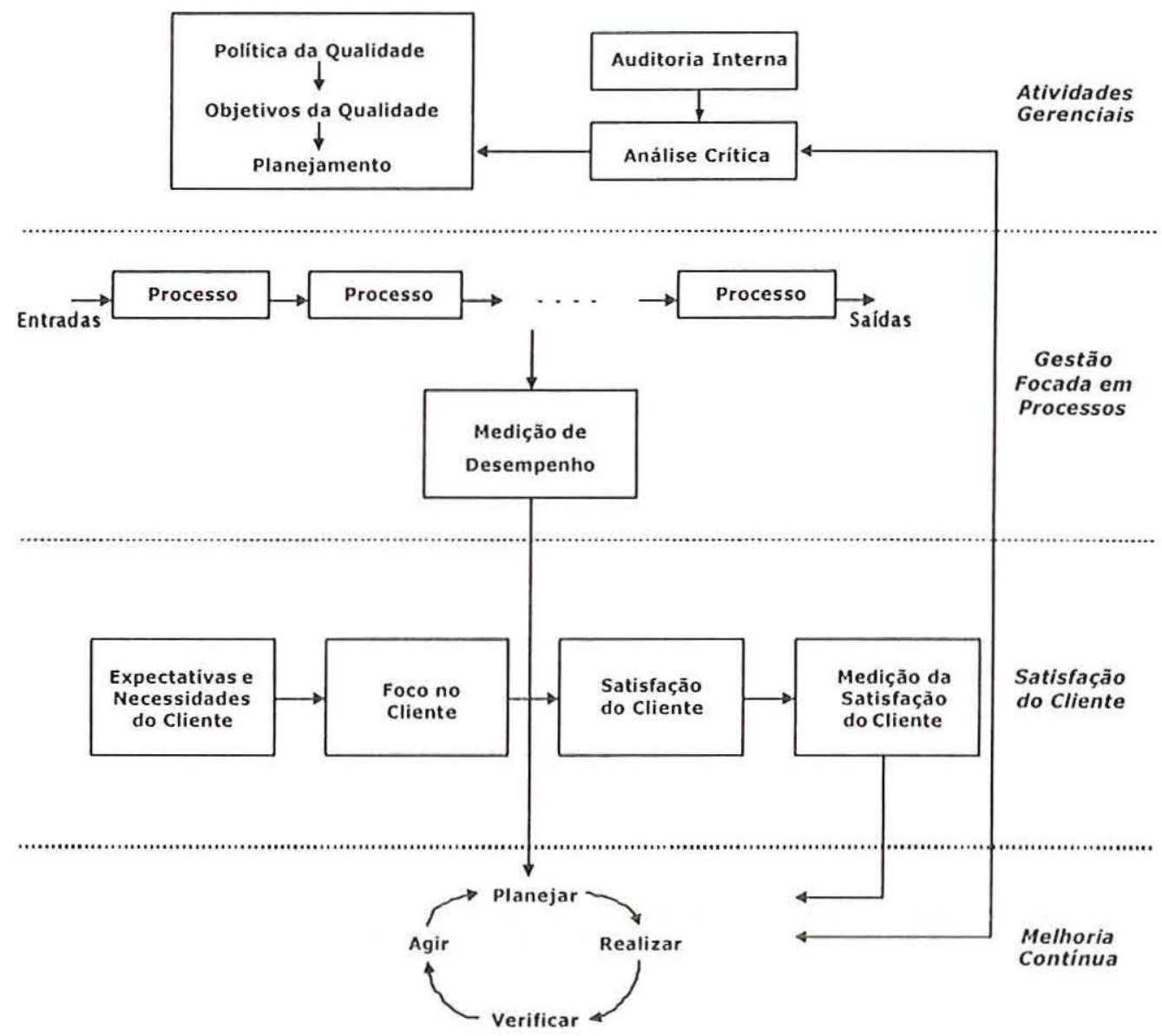

Figura 8 - Modelo sistêmico de áreas chave da ISO 9001:2000

(TSIM, YEUNG e LEUNG, 2002).

As atividades gerenciais devem garantir que a Alta Direção assuma a responsabilidade para definir a direção da organização e o propósito dos negócios. Assim, a política da qualidade e os objetivos da qualidade devem ser definidos e comunicados por toda a organização e aplicados em todas as funções relevantes da empresa. Através da adoção de uma gestão focada nos processos, os processos da organização e suas inter-relações podem ser visualizados. Com isso, o desempenho de cada processo pode ser mensurado contra os resultados planejados. Com base nas informações obtidas na medição dos processos e na medição da satisfação do cliente, a organização pode determinar as áreas para a melhoria contínua. Essas informações podem ser utilizadas nas atividades gerenciais através da análise crítica da adequação da política da qualidade e dos objetivos da qualidade, bem como da efetividade do sistema de gestão (TSIM, YEUNG e LEUNG, 2002). 


\subsubsection{Auditorias da qualidade}

De acordo com a norma ISO 19011 (ISO, 2002a) a auditoria pode ser compreendida como "um processo sistemático, documentado e independente para obter evidências de auditorias e avaliá-las objetivamente para determinar a extensão na qual os critérios de auditoria são atendidos".

As auditorias do sistema de gestão da qualidade podem ser primeira, segunda ou terceira parte. As auditorias de primeira parte ou auditorias internas são realizadas pela própria organização para propósitos internos a fim de atender os requisitos ISO 9001:2000. As auditorias de segunda parte são realizadas principalmente por clientes com a finalidade de verificar o atendimento dos requisitos estabelecidos. As auditorias de terceira parte, também conhecidas como auditorias externas são realizadas por organismos independentes ou certificadoras para atestar a implementação e manutenção do sistema de gestão da qualidade da organização em conformidade com os requisitos estabelecidos, como por exemplo, os requisitos ISO 9001:2000.

As atividades de auditoria envolvem a coleta e a verificação de informações até a elaboração das conclusões de auditoria. A Figura 9 apresenta uma visão geral do processo de auditoria proposto na norma ISO 19011.

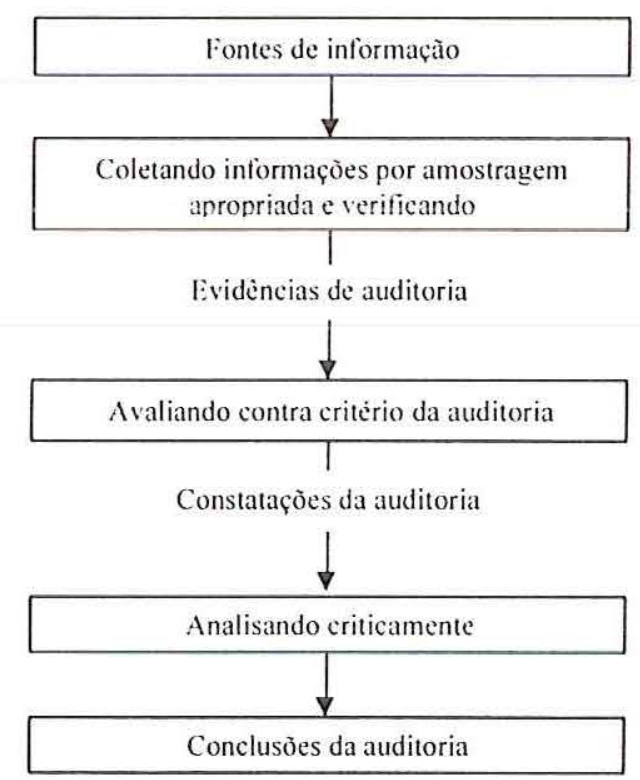

Figura 9 - Visão geral do processo de auditoria (ISO, 2002a). 
As auditorias geralmente são realizadas com o objetivo de verificar a aderência aos requisitos normativos aplicáveis. Desse modo, as conclusões de auditoria abrangem observações, conformidades e não-conformidades. As observações são aplicadas quando um requisito está sendo atendido parcialmente, enquanto que as nãoconformidades são aplicadas quando as práticas avaliadas não atendem aos requisitos aplicáveis. Deste modo, as práticas de auto-avaliação diferemrse das práticas de auditoria por permitirem a identificação de pontos-fortes e oportunidades para melhoria, além de proporcionar a identificação do grau de maturidade das práticas avaliadas contra os critérios de avaliação.

\subsubsection{Razões para a certificação ISO 9000}

Diversos autores (CORBETT, LUCA e PAN, 2003; PALADINI, 2003; STEVENSON e BARNES, 2001) têm apresentado várias razões que justificam a busca pela certificação ISO 9000 Entre elas, podemos destacar:

$>$ exigência dos clientes;

$>$ vantagem competitiva;

$>$ melhoria da qualidade;

$>$ estratégia de marketing;

$>$ redução de custos;

$>$ certificação dos concorrentes;

$>$ relatos de ganhos de empresas certificadas;

$>$ reconhecimento internacional;

Conforme exposto acima, há várias razões para uma organização buscar a certificação ISO 9000. Tais razões podem variar de uma organização para outra, de acordo com a necessidade da empresa. Jones, Arndt e Kustin (1997) apontam três categorias ou razões para a certificação:

1. Desenvolvimento: refere-se ao desejo de melhorar os processos internos de uma organização, bem como o de aumentar o seu desempenho competitivo;

2. Não-desenvolvimento: refere-se aos requisitos dos principais clientes, sem o intuito de investir em processos e novos mercados, é um requisito para os negócios ou um instrumento de marketing;

3. Razões mistas: constitui a combinação das duas categorias anteriores. 


\subsubsection{Principais críticas}

As principais críticas a respeito das normas ISO 9000, segundo Curkovic e Pagell (1999) concentramrse no enfoque limitado sobre melhoria contínua e satisfação do cliente, nos custos de certificação, na capacidade de uma organização certificada produzir com baixa qualidade e na quantidade de documentação aparentemente desnecessária.

Seddon (1997) declara que as normas ISO 9000 têm prejudicado a posição competitiva de muitas organizações. Para sustentar essa declaração, o autor lista 10 argumentos contra as normas ISO 9000:

1. A ISO 9000 incentiva as organizações a agirem de modo a tornar as coisas piores para seus clientes. Ao invés de fazer o que deve ser feito, organizações acabam fazendo coisas que não agregam valor, concentrando-se nas normas internas;

2. Qualidade pela inspeção não é qualidade. A inspeção aumenta os erros, adiciona custos e diminui o moral das pessoas;

3. A ISO 9000 parte do princípio de que o trabalho pode ser controlado através da especificação e controle de procedimentos. A ênfase nos documentos implica grandes esforços para a elaboração e execução dos procedimentos comprometendo o desempenho organizacional e eliminando a inovação;

4. O método de implementação gera sub-otimização de desempenho. O desempenho da organização limita-se ao alinhamento dos requisitos e o foco da implementação é a criação da documentação necessária;

5. A norma está sujeita a interpretações da qualidade por pessoas, principalmente por auditores. Os problemas de interpretação podem comprometer a avaliação da qualidade;

6. A norma promove, encoraja e demanda ações que geram sub-otimização. Requisitos de controle e inspeção são exemplos de sub-otimização;

7. Quando as pessoas estão sujeitas a controles externos, elas podem priorizar aquilo que é controlado. As pessoas fazem aquilo que foi estabelecido e não o que tem que ser feito visando apenas a certificação;

8. A ISO 9000 tem desencorajado os gerentes a aprender sobre a teoria da variação. Muitos gerentes não estão olhando a organização como um sistema e não 
estão aprendendo sobre qualquer variação percebida, pois acreditam que a aderência aos procedimentos pode reduzir a variação;

9. A ISO 9000 tem falhado em fomentar uma boa relação cliente-fornecedor: A ISO 9000 encoraja uma visão contratual obrigando os fornecedores a buscar a certificação ou fazer coisas que sub-otimizam uma boa relação;

10. A ISO 9000 não encoraja os gerentes a pensar de modo diferente. A idéia de controle (gerentes decidem e trabalhadores executam) implícita na ISO 9000 gera sub-otimização.

Stevenson e Barnes (2002) declaram que algumas críticas indicam que a ISO 9000 é genérica e não considera os problemas específicos de algumas indústrias. Para ilustrar essa deficiência, os autores citam o exemplo da indústria automotiva que, no final da década de 80 considerou as normas ISO 9000 inadequadas para atender as necessidades deste setor. Desse modo, com a permissão da ISO, a norma QS-9000 foi desenvolvida com base nos requisitos ISO 9000 para suprir as necessidades da indústria automotiva.

Os resultados mais expressivos de uma pesquisa survey envolvendo gerentes e representantes de 200 organizações britânicas certificadas (DOUGLAS, COLEMAN e ODDY, 2003) revelam que $78 \%$ dos respondentes concordam com a afirmação de que a efetividade da ISO 9000 depende de uma cultura de mudança. Além disso, uma grande parte dos respondentes ( $72 \%$ ) acredita que uma empresa certificada pode produzir com pouca qualidade.

O fato de uma organização ser certificada não garante que seus produtos e serviços sejam superiores quando comparados com uma organização não certifícada. Desse modo, é possivel que os produtos e serviços de uma empresa não tenham qualidade superior, mas tenham uma constante qualidade dos produtos e serviços produzidos de acordo com os padrões estabelecidos (MEEGAN e TAYLOR, 1997).

Na visão de Caillibot (2001), a versão 1994 foi criticada principalmente por enfatizar documentos e registros. Segundo Curkovic e Pagell (1999), muitas das críticas a respeito da ISO 9000 parecem superficiais. Contudo, as empresas que enxergarem o sistema como uma vantagem, poderão obter resultados significativos, enquanto que, aquelas que compreenderem a certificação como um processo incapaz de agregar valor, poderão perder uma excelente oportunidade para melhorar sua posição competitiva. 
Um estudo realizado por Prancic e Turrioni (2001) apresenta algumas possibilidades de minimização das críticas a respeito da ISO 9000, bem como sua eliminação. Nesse sentido, são apresentadas justificativas para as seguintes críticas:

excesso de documentação: é a empresa que define o escopo em que deve estar inserido o seu sistema de gestão da qualidade;

problemas de interpretação: a mudança na terminologia tornou a norma mais clara e genérica permitindo a sua adoção por qualquer organização;

sub-otimização: a organização pode até certificar-se de maneira sub-otimizada, porém deve ser evidenciada a melhoria contínua;

foco interno: a organização deve prover-se das informações necessárias para assegurar e aumentar a satisfação do cliente;

foco no cliente: a organização deve identificar claramente as necessidades do cliente e fornecer todas as informações necessárias durante a realização do produto e após a entrega, bem como medir a satisfação do cliente e tomar as ações necessárias para a correção de eventuais reclamações;

$>$ variação no processo: tais variações devem ser tratadas como ações preventivas;

melhoria contínua: a organização deve definir ações para a melhoria do desempenho organizacional, comparando a efícácia das atividades executadas.

$>$ integração entre os requisitos da qualidade e os requisitos da organização: os objetivos da organização devem estar alinhados com a política da qualidade da empresa e análises críticas devem incluir a verificação do cumprimento destes objetivos;

relações cliente-fornecedor: a organização deve avaliar periodicamente seus fornecedores.

\subsubsection{Benefícios decorrentes da certificação}

Embora seja possivel encontrar muitas críticas a respeito das normas ISO 9000, vários estudos comprovam que empresas certificadas nesses padrões estão satisfeitas com os benefĩcios proporcionados pela certificação. Uma pesquisa survey conduzida por Corbett, Luca e Pan (2003) envolvendo 5.398 organizações certificadas nas normas ISO 9000 em quinze países, revela que as empresas pesquisadas relataram ter grandes benefícios relacionados à melhoria da qualidade, satisfação do cliente, procedimentos e imagem corporativa. 
Em um outro estudo realizado por Lee, Leung e Chan (1999) abrangendo 1.085 empresas foi possível demonstrar, através de uma pesquisa survey, que um percentual significativo dessas organizações concorda que a certificação pode gerar benefícios como: procedimentos esclarecedores (96\%); melhoria na qualidade do produto ou serviço $(88 \%)$; espírito de equipe $(77 \%)$, melhor controle dos fornecedores $(73 \%)$; aumento da eficiência (65\%); e diminuição de reclamações de clientes $(62 \%)$.

Singels, Ruël e Water (2001) consideram que os benefícios proporcionados pela certificação ISO 9000 podem ser divididos em benefícios internos e externos. Benefícios internos são aqueles relacionados às funções internas da organização, envolvendo a estrutura e os processos da empresa. Exemplos de benefícios internos são:

aumento da produtividade;

aumento da eficiência;

redução de custos e desperdícios;

melhor controle administrativo;

responsabilidades e tarefas claramente definidas;

suporte na tomada de decisão;

motivação das pessoas.

Na visão de Singels, Ruël e Water (2001), os benefícios externos estão relacionados ao ambiente vivenciado pela organização como:

vantagem competitiva;

aumento nas vendas;

possibilidade de entrar em novos mercados;

feedback dos clientes;

aumento da satisfação do cliente;

melhoria da imagem;

De um modo geral, os benefícios proporcionados pela ISO 9000 podem variar de acordo com a realidade da organização, ou seja, de acordo com o ambiente vivenciado e suas particularidades, tais como porte, faturamento, atividade, etc. Como se pode observar, os benefícios declarados acima são coerentes com as razões para se buscar uma certificação apresentadas anteriormente. 


\subsubsection{O processo de certificação}

A correta interpretação dos requisitos ISO 9001:2000 é uma condição sine qua non para uma implementação eficaz. Entretanto, esta não é a única dificuldade para as organizações que desejam certificar seu sistema de gestão da qualidade. O processo de implantação dos requisitos ISO 9001:2000 requer um roteiro para a realização das atividades necessárias à implantação.

Para conseguir a certificação, uma organização deve submeter-se a uma auditoria realizada por um organismo certificador independente. Este processo pode ser moroso e desanimador, além de demandar recursos como tempo e dinheiro. Entretanto, vários livros e artigos têm sido escritos com o objetivo de melhorar a compreensão deste processo fornecendo instruções passo-a-passo para uma certificação bem sucedida. Freqüentemente, estas instruções apresentam uma seqüência de etapas para a certificação. (STEVENSON e BARNES, 2001). O Quadro 4 ilustra essas etapas.

Quadro 4: Processo de certificação ISO 9000

Processo de Centificaçáo ISO 9000

1. Diagnóstico ISO 9000. O diagnóstico inicial é uma análise detalhada dos procedimentos e do sistema da qualidade da organização comparados aos requisitos ISO 9000. Este processo define o escopo do projeto ISO 9000.

2. Treinamento. Todos os funcionários devem ser treinados. Primeiro, eles devem ter uma compreensão geral dos requisitos e vocabulário da ISO 9000 , da função do Manual da Qualidade e dos benefícios proporcionados pelo sistema. Segundo, eles devem compreender os procedimentos de melhoria das atividades do dia-a-dia.

3. Documentação das Instruções de Trabalho. Todos os procedimentos devem ser descritos e documentados de modo que possam ser compreendidos antes de sua aprovação. Estes documentos devem resumir todos os processos que afetam a qualidade do produto final.

4. Manual da Qualidade. As normas ISO 9000 exigem que a organização documente todas as atividades que afetam a qualidade do produto final. O Manual da Qualidade é muitas vezes utilizado para agrupar todos os documento em um único documento.

5. Auditoria de Certificação. A etapa final no processo de certificação é a realização de uma auditoria feita por um organismo certificador escolhido pela organização para avaliar a efetividade do Manual da Qualidade e adequação aos requisitos normativos.

Fonte: Processo de certificação ISO 9000 (STEVENSON e BARNES, 2001). 
A International Organization for Standardization (2004) recomenda uma seqüência de 13 passos para a implantação do sistema de gestão da qualidade ISO 9000 :

1. Identificar os objetivos a serem alcançados. Estes objetivos podem compreender um aumento da eficiência e lucratividade, satisfação do cliente, posição de mercado, redução de custos, melhoria da comunicação e moral na organização.

2. Identificar as expectativas das partes interessadas. Tais expectativas referem-se às necessidades dos clientes, colaboradores, fornecedores, acionistas e da sociedade em geral.

3. Obter informações sobre a família ISO 9000. Várias informações a respeito da ISO 9000, tais como requisitos e estudos de caso podem ser encontradas nas normas, web site ISO e em periódicos especializados.

4. Aplicar as normas ISO 9000 no sistema de gestão. Estas normas podem ser utilizadas para fins de certificação (ISO 9001:2000) ou auto-avaliação (ISO 9004:2000).

5. Obter guias ou normas específicas dentro do sistema de gestão da qualidade. Diz respeito a normas especificas pertinentes, de acordo com a necessidade ou atividade da organização, como por exemplo: ISO 10006 - gestão de projetos; ISO 10015 treinamento; ISO/TS 16949 - automotiva.

6. Estabelecer a situação atual, determinar as lacunas entre o sistema de gestão da qualidade e os requisitos da ISO 9001:2000. Este passo pode ser executado através de auto-avaliação ou avaliação realizada por uma organização independente.

7. Determinar os processos necessários ao fornecimento de produtos para os clientes. Envolve a análise dos requisitos da seção 7 da norma ISO 9001:2000 para a determinação da aplicação destes requisitos, incluindo: processos relacionados ao cliente, projeto e/ou desenvolvimento, aquisição, controle operacional e medição e monitoramento.

8. Desenvolver um plano para eliminar as lacunas do passo 6 e desenvolver os processos determinados no passo 7 . Os requisitos 4.1 e 7.1 da norma ISO 9001:2000 fornecem informações para o desenvolvimento do plano.

9. Executar o plano. Implementação das ações identificadas e andamento das ações pendentes.

10. Submeter-se a uma avaliação interna periódica. A norma ISO 19001 fornece diretrizes para a execução deste passo. 
11. Necessita demonstrar conformidade? Se sim, deve-se seguir passo 12. Se não, seguir passo 13.

12. Submeter-se a uma auditoria independente. Para seguir este passo é necessário o engajamento no processo de certificação por um organismo independente e o alinhamento do sistema de gestão da qualidade aos requisitos ISO 9001:2000.

13. Melhorar continuamente o negócio. Ou seja, rever a eficácia e adequação do sistema de gestão da qualidade. A ISO 9004:2000 fornece uma metodologia para a melhoria do sistema.

\subsubsection{Considerações finais sobre as normas ISO 9000}

Desde a sua primeira publicação em 1987, as normas ISO 9000 têm sido discutidas entre as principais comunidades em todo o mundo. As principais críticas a respeito deste conjunto de normas condenam o excesso de documentação, a falta de uma abordagem por processos capaz de gerar valor ao cliente, a falta de um modelo direcionado à melhoria contínua, etc. Entretanto, tais críticas foram levadas em consideração durante a nova revisão que ocorreu no ano de 2000.

Os princípios de gestão intrínsecos nas normas ISO 9000 estão alinhados aos valores postulados nos modelos de excelência empregados em vários prêmios de qualidade e representam o estado da arte na gestão de negócios. Assim, a busca pela adequação às normas ISO 9001:2000 não deve ser encarada simplesmente como uma imposiçào de mercado ou uma panacéia e sim como uma iniciativa para a melhoria do desempenho organizacional.

\subsection{Modelos de excelência}

\subsubsection{Prêmios da Qualidade}

Nos últimos anos, muitos países vêm adotando modelos de excelência para reconhecer as práticas exemplares de várias organizações e disseminar a cultura da qualidade. Os prêmios da qualidade caracterizam-se por seus critérios de avaliação que refletem o estado da arte dos conceitos relacionados à gestão estratégica da qualidade. 
Para Ghobadian e Woo (1996), vários fatores têm encorajado muitos países a introduzir prêmios da qualidade locais, nacionais e transnacionais. Entre eles, a relevância da qualidade como um elemento essencial para o aumento da competitividade, a contribuição de benckmarking, as técnicas de auto-avaliação para a melhoria do desempenho e o sucesso do prèmio Deming, o qual permitiu a difusão das práticas voltadas à qualidade no Japão. Segundo os autores, esses prèmios objetivam:

demonstrar a importància de se produzir com qualidade e o interesse na gestão da qualidade devido a sua importante contribuição para o aumento da competitividade;

encorajar sistemáticas de auto-avaliação contra critérios estabelecidos e necessidades de mercado;

fomentar a cooperação entre organizações;

estimular o compartilhamento e a disseminação de informações referentes ao desdobramento de estratégias bem sucedidas e sobre os benefícios decorrentes da implementação destas estratégias;

promover a compreensão dos critérios para a obtenção da excelência em qualidade e o desdobramento eficaz da gestăo da qualidade;

estimular a adoção da gestão da qualidade para a melhoria dos processos.

Slack et al. (1997) compartilham a idéia de que vários prêmios foram desenvolvidos desde os anos 50 visando reconhecer os esforços de líderes em prol da qualidade e estimulando várias organizações a buscar o desenvolvimento da qualidade. Entre os prêmios mais reconhecidos globalmente estão o Prêmio Deming (Deming Prize), o Prêmio Nacional Malcolm Baldrige (National Malcolm Baldrige Quality Award) e o Prêmio Europeu da Qualidade.

\subsubsection{O Prêmio Deming}

O prêmio Deming de Qualidade foi instituido no Japão em 1951 por um corpo de diretores da União dos Engenheiros e Cientistas do Japão - JUSE com o propósito de difundir a fillosofia da qualidade através do reconhecimento da melhoria do desempenho de organizações que aplicam técnicas de controle da qualidade. O prêmio prescreve abordagens e técnicas especificas, além de admitir que a garantia da qualidade é apenas um aspecto, visto que a qualidade final é o resultado final de um número de ações, fatores e processos (GHOBADIAN e WOO, 1996). 
Para Walton (1989), o processo de avaliação envolve uma comissão premiadora, a qual é constituída por acadêmicos e especialistas renomados que se dividem em equipes de pesquisa para examinar as informações contidas numa candidatura. Desta forma, os juízes analisam as listas de verificação com base nos seguintes pontos:

política e planejamento: Qual é a política da qualidade e de controle estatístico da qualidade da organização? Como esta política, assim como os objetivos são estabelecidos e comunicados e como os resultados são avaliados? Qual é a relação entre os planos a curto e longo prazo?

administração: Qual é a cadeia de responsabilidade? Como se delega poder? Qual é a relação entre as divisões? Como é aproveitado o pessoal das atividades-meio? As atividades dos círculos de controle da qualidade são eficazes?

> educação: Quais são as atividades educacionais da organização incluindo as áreas de controle da qualidade e métodos estatísticos? Como são disseminadas e quais são os resultados destas atividades? Qual é a instrução para os círculos de controle da qualidade e para os fornecedores? Qual é o sistema de sugestões aplicado?

$>$ informação: Quais são as fontes de informação, como ela é comunicada e com que rapidez? Que análise estatística se aplica para a análise dessas informações?

$>$ análise: Qual é a qualidade da análise em relação aos problemas abordados, dos métodos aplicados e dos resultados?

> padronização: Como são estabelecidos, revisados e aplicados os padrões da organização? Como são empregados os métodos estatísticos e quais os resultados obtidos?

controle: Qual é o sistema de controle da qualidade, custo e quantidade? Qual é a extensão de aplicação dos métodos estatísticos? Quais são as contribuições dos círculos de controle da qualidade? Até que ponto o sistema e as atividades de controle são eficazes?

garantia da qualidade: Quais são as normas utilizadas para conseguir qualidade, segurança, prevenção dos perigos de mau funcionamento dos produtos, bem como a adoção de métodos estatísticos e a avaliação da qualidade?

efeitos: Quais são os efeitos e como são medidos?

planos para o futuro: Qual o nível de compreensão da situação atual da organização? Quais são os planos para minimizar os problemas e promover o interesse da organização? Quais são os planos à longo prazo? 
O Prêmio Deming possui duas categorias de premiação: o Prêmio Deming Pessoal e o Prêmio Deming de Aplicação, o qual possui subcategorias para grandes e pequenas empresas, divisões e fábricas. Para ter o direito de se candidatar ao prêmio, a organização precisa atingir uma pontuação entre 70 a 100 pontos. Além disso, deve-se assegurar o compromisso com a qualidade, possuir um sistema de gestão, aplicar métodos estatísticos, ter um plano à longo prazo de aperfeiçoamento contínuo, promover a educação para os empregados e fornecedores e assegurar o foco no cliente. (WALTON, 1989).

\subsubsection{O Prêmio Malcolm Baldrige}

O prèmio nacional da qualidade Malcolm Baldrige foi criado em 1987 com o objetivo de promover a gestão da qualidade e ajudar a revitalização da economia americana na década de 90. Desde então, os Critérios do modelo Malcolm Baldrige para a excelência do desempenho vèm sendo amplamente utilizados como ferramenta para a melhoria e auto-avaliação. Atualmente, o prêmio é administrado pelo Instituto Nacional de Normas e Tecnologia (NIST) e sua estrutura é constituída por sete critérios: liderança, planejamento estratégico, Foco no mercado e no cliente, Medição, análise e gestão do conhecimento, foco nos recursos humanos, gestão de processos e Resultados dos negócios. Estes são a base para a candidatura ao prêmio e para a auto-avaliação das organizações. (NIST, 2004). A Figura 10 ilustra a estrutura do modelo de excelência Malcolm Baldrige.

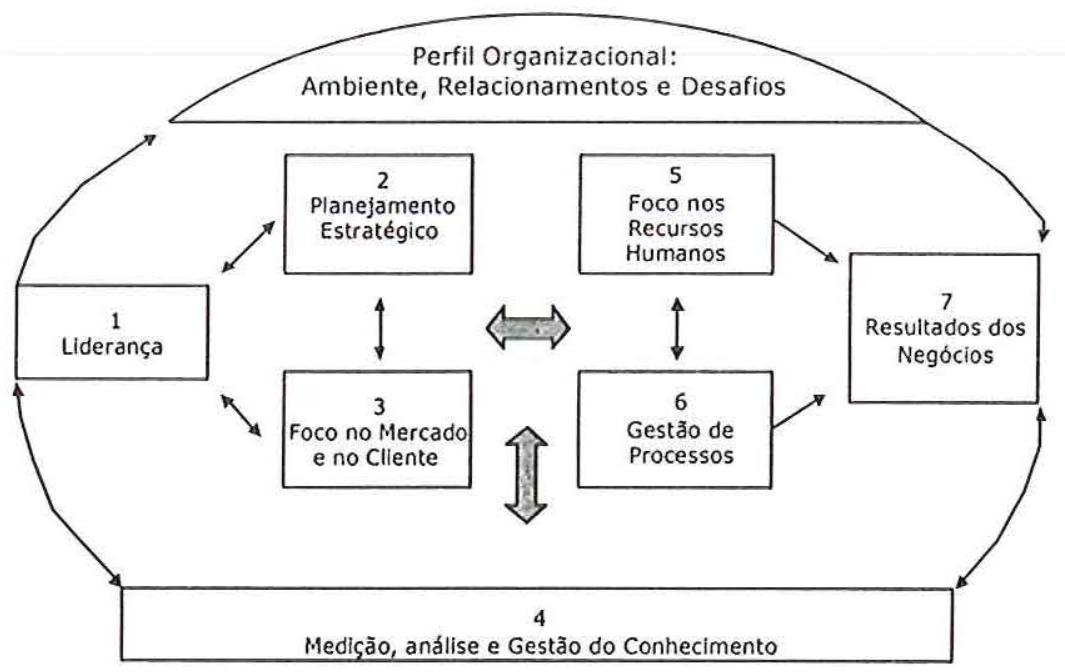

Figura 10 - Estrutura Baldrige e Critérios para a Excelência do Desempenho (NIST, 2004). 
De acordo com Brown (1995), algumas organizações modificam os critérios do Baldrige de modo a adaptá-los a realidade da própria empresa. Assim, os critérios do Baldrige podem ser utilizados para avaliar e aprimorar as organizações, sem a pretensão de candidatura ao prèmio.

\subsubsection{O Prêmio Europeu da Qualidade - EFQM}

Lançado oficialmente em 1991, o Prêmio Europeu da Qualidade, agora reconhecido como EFQM foi desenvolvido com base no modelo americano Malcolm Baldrige e no Prêmio Deming do Japão. A European Foundation for Quality Management - EFQM foi fundada em 1988 por líderes de quatorze empresas européias (Bosch, BT, Bull, Ciba-Geigy, Dassault, Eletrolux, Fiat, KLM, Nestlé, Olivetti, Philips, Renault, Sulzer, Volkswagen) e atualmente, conta com mais de setecentos membros (EFQM, 2004).

O Modelo de Excelência da EFQM ilustrado na Figura 11 baseia-se na premissa de que resultados excelentes no que se refere ao desempenho, clientes, pessoas e sociedade são alcançados através da liderança na condução da política e estratégia, que por sua vez é transferida por meio das pessoas, das parcerias e recursos, e dos processos. As setas ilustram a dinâmica do modelo e mostram a inovação e a aprendizagem necessária para apoiar a melhoria dos meios que conduzem a melhores resultados. Os critérios de meios referentse à forma como as organizações executam suas principais atividades e os critérios resultados referemrse à forma como estes resultados são alcançados. (EFQM, 2004).

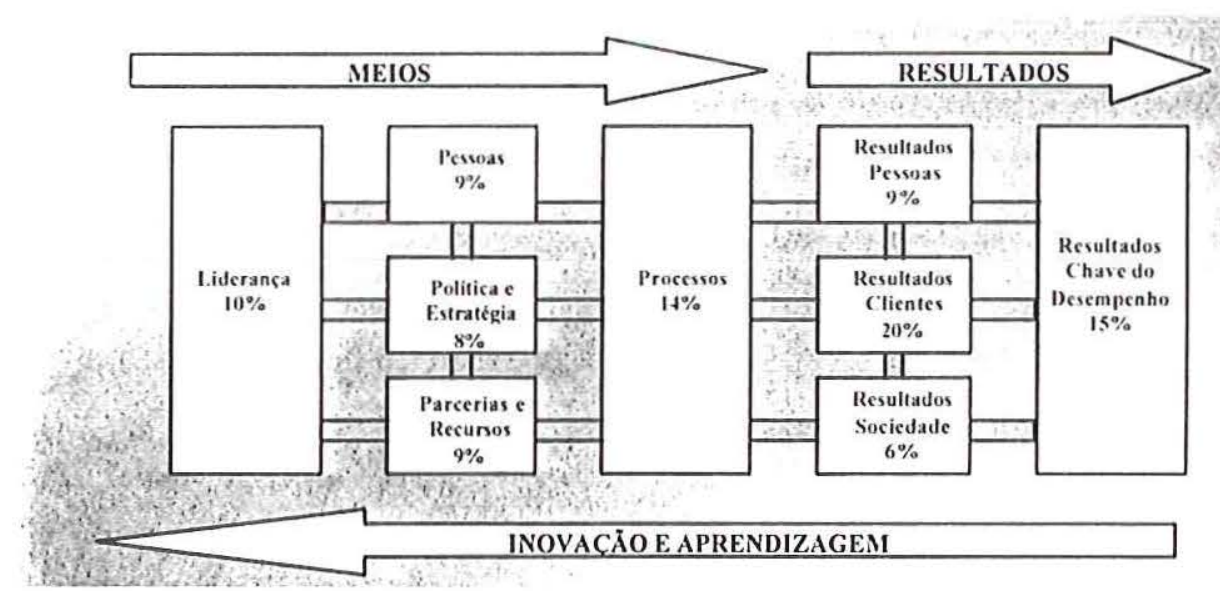

Figura 11 - Modelo de Excelência da EFQM (EFQM, 2004). 


\subsubsection{Comparações entre os prêmios da qualidade e a ISO 9000}

Ao comparar os prèmios Deming, MBNQA e EFQM, Ghobadian e Woo consideram que o prèmio Deming não possui uma estrutura interligando os conceitos, atividades, processos e resultados. Ele apenas fornece uma lista de práticas de gestão desejáveis, além de prescrever ferramentas, técnicas e práticas recomendadas, por exemplo, controle estatístico de processo, círculos de qualidade e padronização. Por outro lado, os prêmios MBNQA e EFQM fornecem um modelo de gestão da qualidade através das partes que o constituem. Além disso, eles são prescritivos apenas em termos de filosofia e valores, não prescrevendo qualquer método ou ferramenta particular para a melhoria da qualidade. O Quadro 5 apresenta os critérios e valores (entre parêntese) dos principais prêmios da qualidade.

Quadro 5 - Comparações entre os principais prêmios da qualidade

\begin{tabular}{|c|c|c|}
\hline Prêmio Deming & $\begin{array}{l}\text { Prêmio Amcrleano da Qualidiade } \\
\text { (MBBN(QA) }\end{array}$ & $\begin{array}{l}\text { Prêmio Eluropeu da Qualidarde } \\
\text { (DFOM) }\end{array}$ \\
\hline Política & Liderança (120) & Liderança (10\%) \\
\hline Organizaçào e Gestào & Planejamento estratégico (85) & Pessoas $(9 \%)$ \\
\hline Educação e disseminaçào & Foco no mercado e no cliente (85) & Politica e estratégia ( $8 \%$ ) \\
\hline \multirow{2}{*}{$\begin{array}{l}\text { Coleta, disseminação e } \\
\text { informação sobre qualidade }\end{array}$} & \multirow{2}{*}{$\begin{array}{l}\text { Medição, análise e gestão do } \\
\text { conhecimento }(90)\end{array}$} & Parcerias e recursos $(9 \%)$ \\
\hline & & Processos $(14 \%)$ \\
\hline Análise & Foco nos recursos humanos ( 85 ) & Resultados pessoas $(9 \%)$ \\
\hline Padronizaçĩo & Gestão de processos (85) & Resultados clientes ( $20 \%$ ) \\
\hline Controle & Resultados do negócio (450) & Resultados sociedade (6\%) \\
\hline Garantia da Qualidade & & Resultados chave do desempenho \\
\hline Efeitos & & $(15 \%)$ \\
\hline nto para o fiu & & \\
\hline
\end{tabular}

Fonte: Adaptado de Ghobadian e Woo (1996).

Há várias comparações entre os Modelos Malcolm Baldrige (MBQA), Prêmio Europeu de Qualidade (EFQM) e as normas ISO 9000 que podem ser encontradas na literatura (TUMMALA e TANG, 1996; BENDELL, 2000; PUN, CHIN e LAU, 1999). Essas comparações envolvem:

$>$ os modelos de excelència MBNQA e EFQM representam um conceito holístico focado na auto-avaliação. Em contrapartida, a ISO 9000 tem um enfoque mais minucioso em relação à não-conformidade;

$>$ a principal proposta dos modelos MBNQA e EFQM é a promoção de uma cultura voltada à qualidade, visando o aumento da competitividade, a compreensão dos critérios de excelência em qualidade e o reconhecimento das melhores práticas das 
organizações. Além disso, o MBNQA requer que as empresas premiadas compartilhem suas práticas com outras organizações. Por outro lado, a principal proposta da ISO 9000 é a implementação de um sistema de qualidade efetivo para assegurar que os produtos e serviços fornecidos aos clientes estão em conformidade com os requisitos estabelecidos;

ambos os modelos MBNQA e EFQM enfatizam dois fatores de competitividade: entrega de valor ao cliente e melhoria de desempenho operacional em toda a organização. O EFQM também enfatiza o desempenho financeiro da organização. A ISO 9000, por sua vez, enfatiza a conformidade com os requisitos especificados no sistema de gestão da qualidade;

$>$ a ISO 9000 considera relevante as atividades de inspeção e testes, e um dos principais conceitos refere-se a implementação e manutenção de um sistema de gestão da qualidade documentado. Os modelos MBNQA e EFQM, por sua vez, enfatizam que a inspeção e testes devem ser substituídos pela prevenção e demonstração de excelência na qualidade dos produtos e serviços;

$>$ requisitos como inspeção e testes, não-conformidade do produto e documentação são indispensáveis para satisfazer os requisitos ISO 9000. Tais requisitos não são enfatizados nos critérios MBNQA e EFQM;

$>$ enquanto os modelos MBNQA e EFQM envolvem mecanismos como altoavaliação, medição do desempenho, qualificação através de visitas in loco e competição, a ISO 9000 envolve seleção de organismos certificadores, submissão de um manual da qualidade, execução de auditorias externas e certificação;

- os requisitos ISO 9000 não abrangem fatores tecnológicos e elementos competitivos.

\subsubsection{O Prêmio Nacional da Qualidade - PNQ}

O prêmio Nacional da Qualidade - PNQ foi instituído em 1991 pela Fundação para o Prêmio Nacional da Qualidade - FPNQ com o propósito de reconhecer anualmente as organizações que se destacam pela excelência da gestão de suas práticas, bem como de seus resultados. Através da divulgação destas práticas reconhecidas como "Classe Mundial", a FPNQ contribui com a melhoria da qualidade na gestão das organizações brasileiras. O modelo de excelência do PNQ foi desenvolvido, desde a sua 
origem em 1991, adotando os fundamentos de excelência do prêmio Malcolm Baldrige. A escolha do modelo Baldrige decorreu de amplo estudo dos prèmios existente no Brasil e no exterior, partindo do precursor de todos, o Deming Prize (Japão). (FUNDAÇÃO PARA O PRÊMIO NACIONAL DA QUALIDADE, 2002a).

O Modelo de Excelència do PNQ pode ser utilizado para a auto-avaliação em qualquer tipo de organização, visto que a linguagem utilizada é flexível e de fácil entendimento, além de não prescrever ferramentas e práticas de gestão específicas. Este modelo é estruturado em oito critérios: Liderança; Estratégias e Planos; Clientes; Sociedade; Informações e Conhecimento; Pessoas; Processos; e Resultados. A incorporação do Modelo de Excelência do PNQ à Gestão da Qualidade da organização pode ser compreendida através da Figura 12.

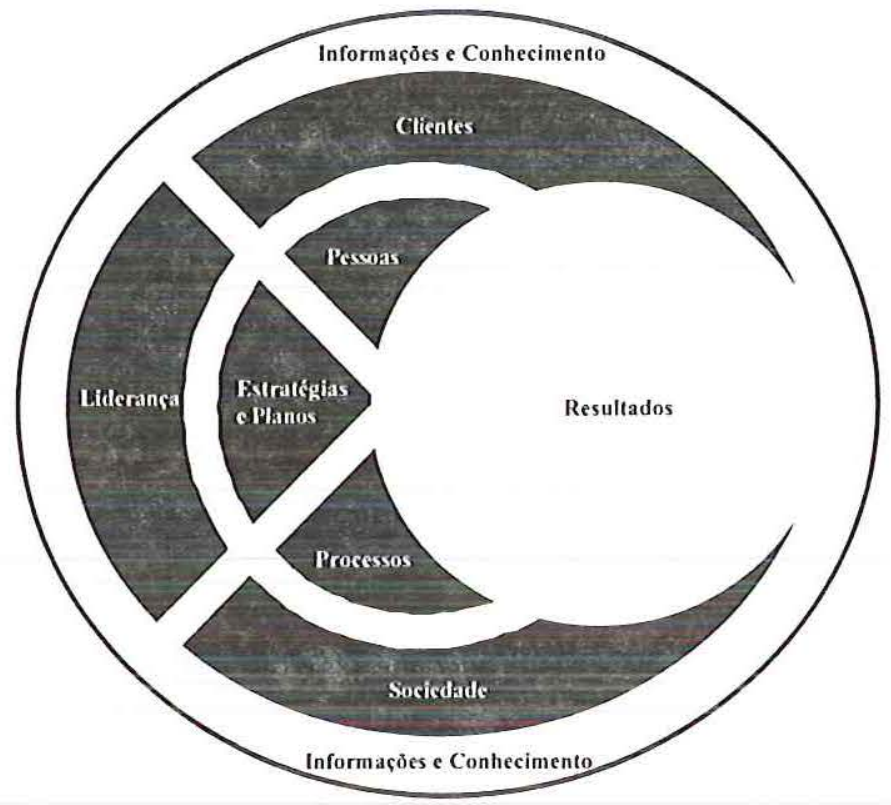

Figura 12 - Modelo de Excelência do PNQ (FPNQ, 2002a).

Em 2002, a FPNQ analisou criticamente outros prêmios reconhecidos internacionalmente em conjunto com as normas ISO série 9000 e 14000. Atualmente, os critérios de excelência do PNQ se apóiam nos seguintes fundamentos: Liderança e constância de propósitos; Visão de futuro; Foco no cliente e no mercado; Responsabilidade social e ética; Decisões baseadas em fatos; Valorização das pessoas; Abordagem por processos; Foco nos resultados; Inovação; Agilidade; Aprendizado organizacional; e Visão sistêmica. 
Nascimento e Alves (2001) consideram que as normas série ISO 9000 podem ser utilizada conjuntamente com o modelo de excelência do PNQ, pois com a revisão de 2000, as normas ISO 9000 passaram a incorporar conceitos mais abrangentes, aproximando os requisitos e as diretrizes presentes nas normas ISO 9000 dos critérios do PNQ. Na visão dos autores, a adoção dos critérios de excelència do PNQ não constitui uma alternativa à certificação com base nas normas ISO 9000, e sim uma ação complementar. O Quadro 6 apresenta a correlação entre os critérios do PNQ e as diretrizes ISO 9004:2000.

Quadro 6 - Correlação entre os critérios do PNQ e as diretrizes ISO 9004

\begin{tabular}{|c|c|c|c|}
\hline \multicolumn{2}{|c|}{$\begin{array}{l}\text { PNQ - } 2004 \\
\text { Itens dos critérios de excelência }\end{array}$} & \multicolumn{2}{|r|}{$\begin{array}{l}\text { NBR ISO 9004:2000 } \\
\text { Diretrizes para melhorias de desempenho }\end{array}$} \\
\hline 1.1 & Sistema de liderança & $\begin{array}{l}5.1 \\
5.5 \\
\end{array}$ & $\begin{array}{l}\text { Responsabilidade da direçào- } \\
\text { Responsabilidade, autoridade e comunicação }\end{array}$ \\
\hline 1.2 & Cultura de Excelència & $\begin{array}{ll}5.3 \\
4.3 \\
\end{array}$ & $\begin{array}{l}\text { Politica da qualidade } \\
\text { Uso dos principios de gestão da qualidade }\end{array}$ \\
\hline 1.3 & Análise Critica do desempenho global & 5.6 & Análise crítica pela alta direção \\
\hline 2.1 & Formulação de estratégias & 5.4 & Planejamento \\
\hline 2.2 & Desdobramento das estratégias & 5.4 & Planejamento \\
\hline 2.3 & Planejamento da medição do desempenho & 8.1 & Medição, análise e melhoria - \\
\hline 3.1 & Imagem e conhecimento de mercado & 7.2 & Processos relacionados as partes interessadas \\
\hline 3.2 & Relacionamento com clientes & $\begin{array}{l}5.2 \\
7.2 \\
\end{array}$ & $\begin{array}{l}\text { Necessidades e expectativas das partes } \\
\text { interessadas } \\
\text { Processos relacionados as partes interessadas }\end{array}$ \\
\hline 4.1 & Responsabilidade sócio-ambiental & $\begin{array}{l}6.7 \\
7.2 \\
\end{array}$ & $\begin{array}{l}\text { Recursos naturais } \\
\text { Processos relacionados às partes interessadas }\end{array}$ \\
\hline 4.2 & Ética e desenvolvimento social & 7.2 & Processos relacionados às partes interessadas \\
\hline 5.1 & Gestão das informaçòes da organização & 6.5 & Informaçào \\
\hline 5.2 & Gestào das informaçòes comparativas & 7.2 & Processos relacionados às partes interessadas \\
\hline 5.3 & Gestào do capital intelectual & $\begin{array}{l}4.2 \\
6.5 \\
\end{array}$ & $\begin{array}{l}\text { Documentação } \\
\text { Informação }\end{array}$ \\
\hline 6.1 & Sistemas de trabalho & 4.1 & Gestão de sistemas e processos \\
\hline 6.2 & Capacitação e desenvolvimento & 6.2 & Pessoas \\
\hline 6.3 & Qualidade de vida & 6.4 & Ambiente de trabalho \\
\hline 7.1 & Gestào de processos relativos ao produto & $\begin{array}{l}7.1 \\
7.3 \\
7.5 \\
8.3 \\
\end{array}$ & $\begin{array}{l}\text { Realizaçào do produto } \\
\text { Projeto de desenvolvimento } \\
\text { Operaçōes de produção e serviço } \\
\text { Controle de não-conformidade }\end{array}$ \\
\hline 7.2 & Gestào de processos de apoio & $\begin{array}{l}7.1 \\
6.3 \\
\end{array}$ & $\begin{array}{l}\text { Realizaçào do produto } \\
\text { Infra-estrutura }\end{array}$ \\
\hline 7.3 & Gestào de processos relativos aos fornecedores & $\begin{array}{l}6.6 \\
7.4 \\
\end{array}$ & $\begin{array}{l}\text { Fornecedores e parceiros } \\
\text { Aquisição }\end{array}$ \\
\hline 7.4 & Gestão econòmico-linanceira & 6.8 & Recursos financeiros \\
\hline 8.1 & Resultados relativos aos clientes e ao mercado & 8.2 & Medição e monitoramento \\
\hline 8.2 & Resultados econòmico-financeiros & 8.2 & Medição e monitoramento \\
\hline 8.3 & Resultados relativos às pessoas & 8.2 & Medição e monitoramento \\
\hline 8.4 & Resultados relativos aos fornecedores & 8.2 & Medição e monitoramento \\
\hline 8.5 & Resultados dos processos relativos ao produto & 8.2 & Mediçào e monitoramento \\
\hline 8.6 & Resultados relativos à sociedade & 8.2 & Medição e monitoramento \\
\hline 8.7 & $\begin{array}{l}\text { Resultados dos processos de apoio e } \\
\text { organizacionais }\end{array}$ & 8.2 & Medição e monitoramento \\
\hline
\end{tabular}

Fonte: adaptado de Nascimento e Alves (2001). 


\subsubsection{Os Primeiros Passos para a Excelência}

Em 1996, a Fundação para o Prêmio Nacional da Qualidade instituiu um modelo simplificado do Prèmio Nacional da Qualidade com o intuito de estabelecer um nível intermediário de excelência. Desta forma, os "Primeiros Passos para a Excelência" foi editado contendo uma estrutura alinhada aos critérios de excelência. Desde então, de acordo com a Fundação para o Prêmio Nacional da Qualidade (2000), Os Primeiros Passos para a Excelência vèm sendo utilizados por várias organizações como instrumento avaliatório, além de servir como referencial para outros prêmios estaduais, setoriais e internos às empresas.

A estrutura dos Primeiros Passos, da mesma forma que o PNQ, compreende os sete critérios de excelência que se subdividem em vinte e seis itens de avaliação. Em 2002 a Fundação para o Prêmio Nacional da Qualidade atualizou a edição Primeiros Passos, a fim de alinhar este modelo com os critérios de Exceiência do PNQ e possibilitar seu uso como um modelo introdutório de auto-avaliação. O Quadro 7 apresenta os critérios, os itens e as pontuaçòes máximas dos Primeiros Passos.

A avaliação das práticas de gestão de uma organização com base nos Primeiros Passos envolve très dimensões e fatores, da mesma forma como ocorre no PNQ. A dimensão enfoque refere-se às práticas de gestão utilizadas pela organização para atender aos requisitos pertinentes, levando em consideração a adequação e exemplaridade destas práticas. A dimensão aplicação refere-se à disseminação e ao uso do enfoque pela organização levando em consideração a disseminação e a continuidade das práticas adotadas. Por fim, a dimensão resultados explora as conseqüencias da implementação das práticas utilizadas, considerando a relevància dos resultados para a organização, o desempenho em relação aos referenciais aplicáveis e tendência desses resultados. (FPNQ, 2002a). 
Quadro 7 - Critérios, Itens e Pontuações Máximas

\begin{tabular}{|c|c|}
\hline Critérios Itens & Pontuação Máxima \\
\hline 1. Liderança & 45 \\
\hline 1.1 Sistema de Liderança & 15 \\
\hline 1.2 Cultura da excelência & 15 \\
\hline 1.3 Análise critica do desempenho global & 15 \\
\hline 2. Estratégias e Planos & 45 \\
\hline 2.1 Formulaçào das estratégias & 15 \\
\hline 2.2 Desdobramento das estratégias & 15 \\
\hline 2.3 Planejamento da medição do desempenho & 15 \\
\hline 3. Clientes e sociedade & 45 \\
\hline 3.1 Imagem e conhecimento de mercado & 15 \\
\hline 3.2 Relacionamento com clientes & 15 \\
\hline 3.3 Interaçào com a sociedade & 15 \\
\hline 4. Informações e conhecimento & 45 \\
\hline 4.I Gestào das informações da organização & 15 \\
\hline 4.2 Gestào das informaçòes comparativas & 15 \\
\hline 4.3 Gestão do capital intelectual & 15 \\
\hline 5. Pessoas & 45 \\
\hline 5.1 Sistemas de trabalho & 15 \\
\hline 5.2 Capacitaçào e desenvolvimento & 15 \\
\hline 5.3 Qualidade de vida & 15 \\
\hline 6. Processos & 45 \\
\hline 6.1 Gestão de processos relativos ao produto & 15 \\
\hline 6.2 Gestão de processos de apoio & 10 \\
\hline 6.3 Gestão de processos relativos aos fornecedores & 10 \\
\hline 6.4 Gestào linanceira & 10 \\
\hline 7. Resultados & 230 \\
\hline 7.1 Resultados relativos aos clientes e ao mercado & 50 \\
\hline 7.2 Resultados tinanceiros & 50 \\
\hline 7.3 Resultados relativos às pessoas & 30 \\
\hline 7.4 Resultados relativos aos fornecedores & 20 \\
\hline 7.5 Resultados dos processos relativos ao produto & 30 \\
\hline 7.6 Resultados relativos à sociedade & 20 \\
\hline 7.7 Resultados dos processos de apoio & 30 \\
\hline Total de Pontos Possiveis & 500 \\
\hline
\end{tabular}

Fonte: FPNQ, 2002a

Os itens correspondentes aos critérios de 1 a 6 são avaliados com base nas dimensòes enfoque e aplicação e estão estruturados conforme a dinâmica do diagrama de gestão apresentado na Figura 13. Esses itens estão divididos da seguinte forma:

aspectos de 1 a 3 - verificação das práticas de gestão, dos padrões de trabalho e do grau de aplicação destas práticas e padrões;

> aspecto 4 - verificação dos métodos de controle das práticas de gestão;

$>$ aspecto 5 - verificação dos métodos de avaliação das práticas de gestão e padrões de trabalho, bem como os métodos para implementar as inovações e melhorias incluindo exemplos de ações pertinentes. 


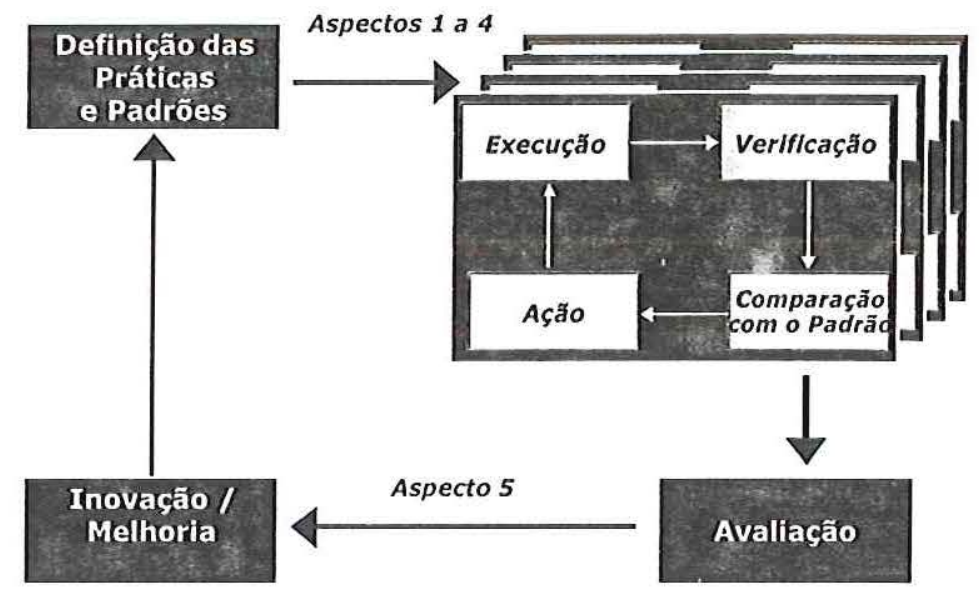

Figura 13 - Diagrama de Gestão adaptados para os Primeiros Passos (FPNQ, 2002).

A avaliação dos itens correspondente ao critério 7 , compreendem a verificação dos níveis atuais de desempenho, das tendências de progresso ou de sustentação dos níveis, de modo a permitir a análise dos indicadores de desempenho, bem como das informações comparativas pertinentes. Dessa forma, cada aspecto de avaliação de enfoque e aplicação (itens 1.1 a 6.4), assim como de resultados (itens 7.1 a 7.7) é avaliado através da uma escala de alternativas que representa o estágio atual das práticas e dos resultados da organização.

A avaliação das práticas de gestão através dos Primeiros Passos permite a identificação do estágio alcançado pela organização na busca pela excelência. A diferença entre o PNQ e os Primeiros Passos é que o primeiro fornece diretrizes para a excelência do desempenho ou práticas reconhecidas como "Classe Mundial", enquanto que o segundo fornece diretrizes para o bom desempenho, ou seja, um estágio bem superior ao praticado pela maioria das organizações. Para a FPNQ (2002b):

Os Primeiros Passos contêm os critérios para um bom desempenho, servem como modelo de gestão e instrumento de diagnóstico da organização e somam 500 pontos, enquanto os 1000 pontos do PNQ representam o estado da arte da gestão para a excelência do desempenho. A estrutura do sistema é a mesma, diferenciando-se pelo grau de maturidade do sistema de gestão da organização, que utiliza um ou outro instrumento.(FPNQ, 2002b). 
Embora a pontuação de seus itens represente $50 \%$ da pontuação dos critérios de excelência, não se pode afirmar que a mesma pontuação obtida nos dois modelos tenha o mesmo significado. Conforme esclarece a FPNQ, (2002b): "o nível de profundidade com que é feita a avaliação pode variar". A Figura 14 apresenta a correlação entre o Prêmio Nacional da Qualidade e os Primeiros Passos para a Excelência. Com base nessa correlação pode-se observar que o modelo PNQ possui um maior nível de detalhamento em relação aos aspectos de avaliação estabelecidos nos Primeiros Passos.

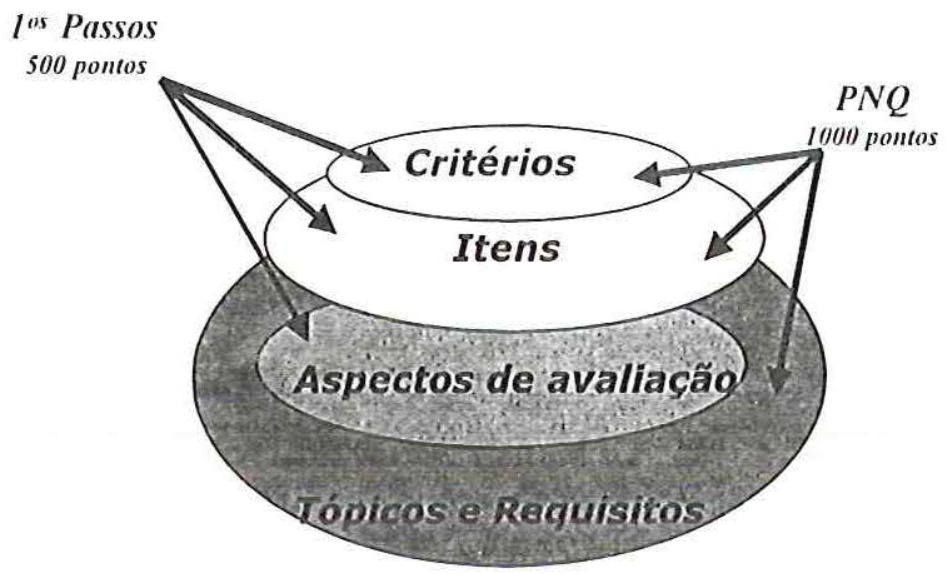

Figura 14 - Correlação entre os Primeiros Passos e o PNQ (FPNQ, 2002b).

\subsubsection{Considerações finais sobre os modelos de excelência}

Os modelos de excelência dos prêmios da qualidade apresentados neste texto vêm sendo adotados por inúmeros países com o objetivo de difundir a cultura da excelência e reconhecer as práticas que refletem o estado da arte na gestão dos negócios. Além disso, esses modelos permitem a prática de auto-avaliação das organizações. O instrumento de auto-avaliação da edição Primeiros Passos oferece uma grande contribuição para a realização deste trabalho, servindo como referencial teórico para a elaboração do modelo de avaliação proposto (FPNQ, 2002b). 
As organizações realizam auto-avaliação por várias razões, como por exemplo, mudanças no ambiente interno e externo, mudanças na direçào e na liderança da empresa, necessidade para desenvolver qualidade baseada em padrões, ou como parte de uma estratégia para a melhoria contínua. Além disso, a auto-avaliação tem um efeito positivo na cultura organizacional. (RITCHIE e DALE, 2000). O Quadro 8 apresenta três categorias de benefícios proporcionados pelo processo de auto-avaliação.

\section{Quadro 8 - Benefícios decorrentes da auto-avaliação}

\begin{tabular}{|ll|}
\hline Categoria & Benefícios \\
\hline Imediato & Facilita benchmarking \\
& Direciona a melhoria continua \\
& Incentiva o envolvimento dos funcionários \\
& Fornece visão à direção \\
& Eleva a compreensão e a conscientização da qualidade \\
& Desenvolve uma abordagem comum para a melhoria em toda a organização \\
& Estratégia de marketing \\
& Gera planos de ação \\
Longo-prazo & Favorece a redução de custo \\
& Melhora os resultados dos negócios \\
& Direciona os investimentos a curto e longo-prazo \\
& Fornece uma abordagem disciplinada para o planejamento \\
& Desenvolve um enfoque holístico para a qualidade \\
& Aumenta a habilidade para reunir e satisfazer as expectativas dos clientes \\
& Mantém a imagem da qualidade \\
Fornece uma ligação entre clientes e fornecedores \\
Viabiliza a conscientização dos funcionários para a qualidade \\
Fornece uma lista de veriticação para processos e operações \\
Incentiva um enfoque para os processos e não apenas para o produto \\
Incentisa a melhoria do desempenho
\end{tabular}

Fonte: Ritchie e Dale (2000).

Os critérios de excelència dos prèmios da qualidade apresentados podem ser usados como instrumento de avaliação da gestão da organização, independente de seu porte e setor econômico de atuação. Assim, os prêmios da qualidade oferecem um modelo para a realização de um diagnóstico da situação atual da organização. Considerando o ambiente extremamente competitivo em que as empresas atuam, uma ferramenta de diagnóstico de tal amplitude de aplicação pode ser extremamente útil, tanto para as organizações como para pesquisadores e profissionais da área. (RUTKOWSKI, 2002). 


\section{Proposta para AVAliaÇão das Práticas de Gestão da QUALIDADE EM RELAÇÃO AOS REQUISITOS ISO 9001:2000}

Neste Capítulo apresenta-se a proposta para o processo de avaliação de sistemas de gestão da qualidade ISO 9001:2000. São fornecidas informações sobre as etapas do processo de avaliação, bem como a aplicação do instrumento avaliatório.

\subsection{A estrutura da proposta}

O trabalho consiste na proposição e aplicação de um processo de avaliação de sistemas de gestão da qualidade ISO 9001:2000. Esta proposta inclui tanto organizações não-certificadas, com o propósito de identificar as lacunas entre as atuais práticas organizacionais e os requisitos ISO 9001:2000, como organizações já certificadas, mas que desejam identificar o estágio de adequação de suas práticas com o intuito de melhorar continuamente seu sistema de gestão da qualidade.

A estrutura do método foi construída com base em dois referenciais teóricos. $\mathrm{O}$ primeiro envolve o estudo da norma ISO 19011 - Diretrizes para Auditorias do Sistema de Gestão Ambiental e da Qualidade (ISO, 2002a) partindo da análise de um processo sistemático para a obtenção e avaliação de evidências objetivas contra critérios estabelecidos. O processo de avaliação proposto envolve também a aplicação de um instrumento simplificado para a avaliação do sistema de gestão da qualidade, que foi elaborado com base no modelo da Fundação para o Prêmio Nacional da Qualidade (2002b), edição "Os Primeiros Passos para a Excelência". Mais adiante apresenta-se em detalhe o instrumento avaliatório incluindo a sistemática de pontuação e os critérios para a identificação do estágio de adequação aos requisitos ISO 9001:2000.

O método é aplicado pelo pesquisador, que exerce o papel de avaliador e deve possuir a competência necessária quanto ao conhecimento das normas que são utilizadas como referencial teórico durante todas as fases do processo de avaliação. O pesquisador deve contar com o apoio de lideranças das empresas avaliadas, de modo garantir a disponibilidade das informações necessárias em todas as etapas do trabalho. 
O processo de avaliação proposto tem como intuito identificar a situação atual do sistema de gestão da qualidade contra os critérios de avaliação que representam os requisitos ISO 9001:2000. Este processo deve ser executado através de cinco passos, objetivando desta forma, a orientação da aplicação instrumento avaliatório, bem como a condução da avaliação.

O primeiro passo consiste no planejamento da avaliação, onde são estabelecidos os objetivos e a abrangência da avaliação, além da definição dos recursos necessários e o cronograma das atividades. O passo seguinte envolve a análise dos documentos coletados e o registro das evidências obtidas a partir da análise da documentação. $\mathrm{O}$ terceiro passo refere-se à verificação in loco, onde se aplica o instrumento avaliatório com base nas entrevistas com os envolvidos nos processos avaliados. O quarto passo consiste na análise das informações e evidências apuradas para o estabelecimento da pontuação dos requisitos avaliados. O último passo, envolve a apresentação dos resultados e a entrega do relatório final à organização avaliada. A Figura 15 ilustra o processo de avaliação proposto.

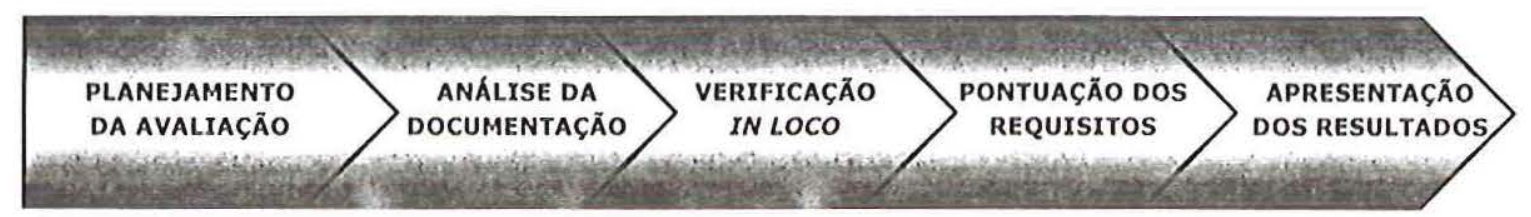

Figura 15 - Processo de avaliação através de cinco passos.

\subsubsection{Passo 1 - Planejamento da avaliação}

A decisão pela aplicação do diagnóstico do sistema de gestão da qualidade deve partir da alta direção da empresa. Após a confirmação da avaliação, a alta direção deve comunicar a realização do trabalho e seus objetivos a todos os envolvidos. O planejamento da avaliação consiste na definição dos objetivos e escopo da avaliação, na definição das responsabilidades durante todas as etapas do processo, na identificação dos recursos necessários para assegurar a eficácia da avaliação e na definição do plano de avaliação, incluindo a definição da agenda e o cronograma das atividades desenvolvidas. A Figura 16 ilustra as atividades pertinentes ao passo 1. 


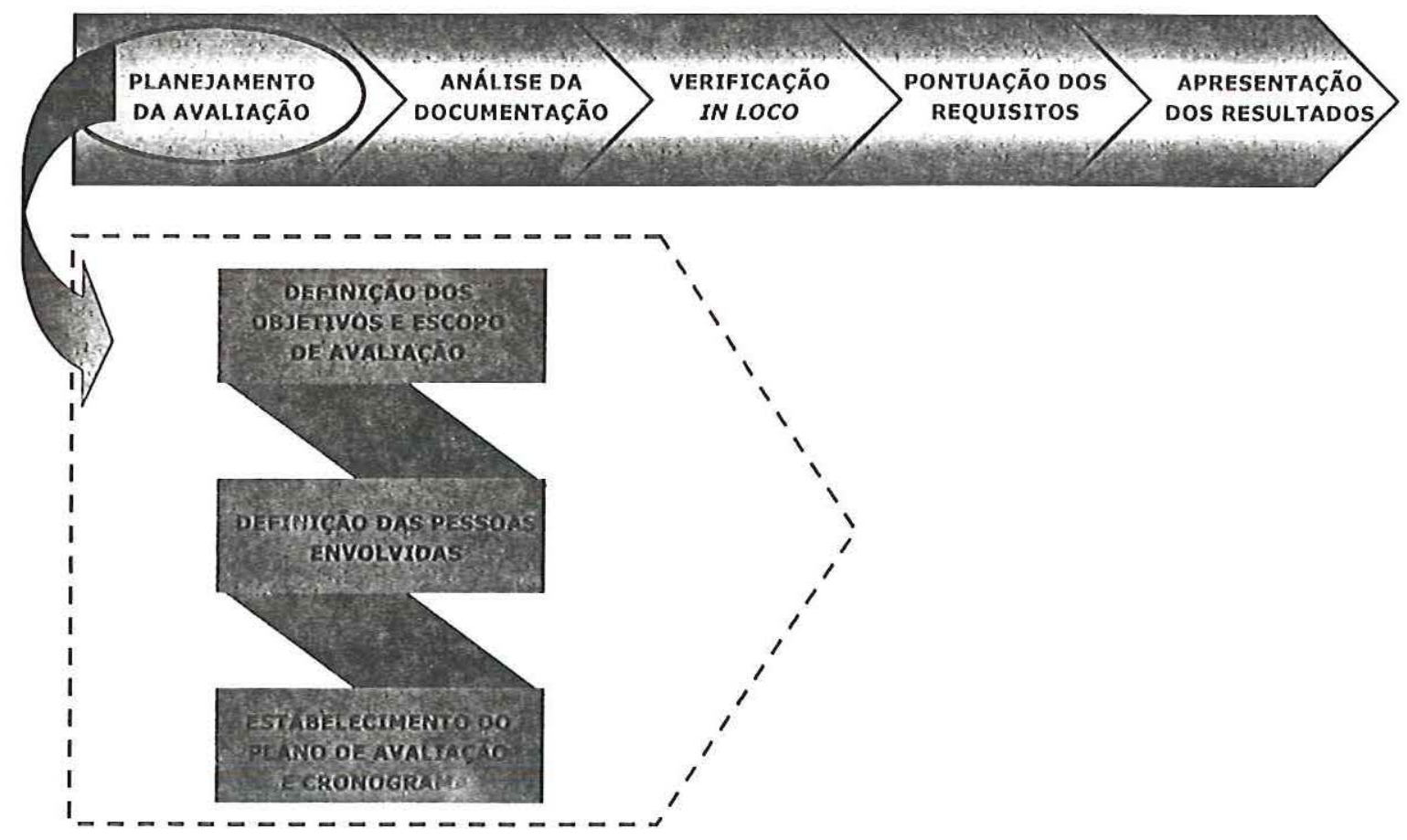

Figura 16 - Atividades ligadas ao Planejamento da avaliação.

Os objetivos devem ser definidos de modo que o resultado da avaliação seja coerente com as necessidades da empresa. Tais necessidades podem surgir em virtude das razões para se buscar a certificação na norma ISO 9001:2000. Além disso, deve-se definir o escopo, ou seja, os produtos e serviços aplicáveis, a abrangência da avaliação considerando a localização das unidades que serão avaliadas, incluindo todos os processos que afetam o sistema de gestão da qualidade da empresa, bem como a duração da avaliação.

A alta direção da empresa deve designar um avaliador com autoridade para gerenciar o processo de avaliação. O avaliador pode selecionar avaliadores auxiliares (colaboradores) adotando como critério para seleção a competência necessária para a realização do processo de avaliação. $\mathrm{O}$ avaliador e seus auxiliares devem:

$>$ definir as responsabilidades pelas atividades;

$>$ definir os recursos necessários;

$>$ fornecer informações a respeito do andamento da avaliação;

$>$ manter registros;

$>$ analisar criticamente os resultados;

$>$ elaborar e distribuir o relatório final de consenso. 
Durante o processo de avaliação, os avaliadores devem estar acompanhados de representantes dos processos envolvidos designados. Tais representantes atuarão como facilitadores auxiliando os avaliadores, estabelecendo contatos, esclarecendo dúvidas e fornecendo informações solicitadas.

A responsabilidade pela aplicação do método é do avaliador que também deve coordenar as reuniões de consenso para a elaboração do relatório final. Para que o processo de avaliação seja eficaz, o avaliador deve possuir as seguintes competências:

$>$ habilidade em técnicas de coleta de dados;

$>$ conhecimento das normas série ISO 9000;

$>$ conhecimento em sistemas de gestão da qualidade e documentos de referência;

$>$ conhecimento das leis. regulamentos e outros requisitos aplicáveis à organização;

$>$ habilidade para compreender o contexto operacional da organização.

Para assegurar a eficácia do trabalho, todos os processos do sistema de gestão da qualidade da organização devem ser contemplados no processo de avaliação. Dessa forma, quando houver situações onde a avaliação não for viável, o avaliador deve buscar uma alternativa junto à alta direção da organização, de modo a assegurar que as evidências objetivas pertinentes sejam disponibilizadas.

Antes de dar início às atividades de avaliação, o avaliador deve elaborar um plano de avaliação, definindo a agenda e o cronograma das atividades de avaliação, bem como estabelecer contato inicial com os envolvidos para o esclarecimento de questões referentes à duração da avaliação, ao acesso à documentação, às normas de segurança pertinentes ao local e as condições necessárias para o processo de avaliação.

\subsubsection{Passo 2 - Análise da documentação}

A análise da documentação abrange a coleta e análise dos principais documentos do sistema de gestão da qualidade da organização, incluindo manuais, procedimentos e registros obrigatórios. Antes de conduzir a avaliação in loco, o avaliador deve solicitar os documentos para a posterior análise e registro das evidências de documentação no instrumento avaliatório. Este passo deverá ser executado levando em consideração o porte, natureza e complexidade da organização. A Figura 17 ilustra as atividades pertinentes a análise da documentação. 


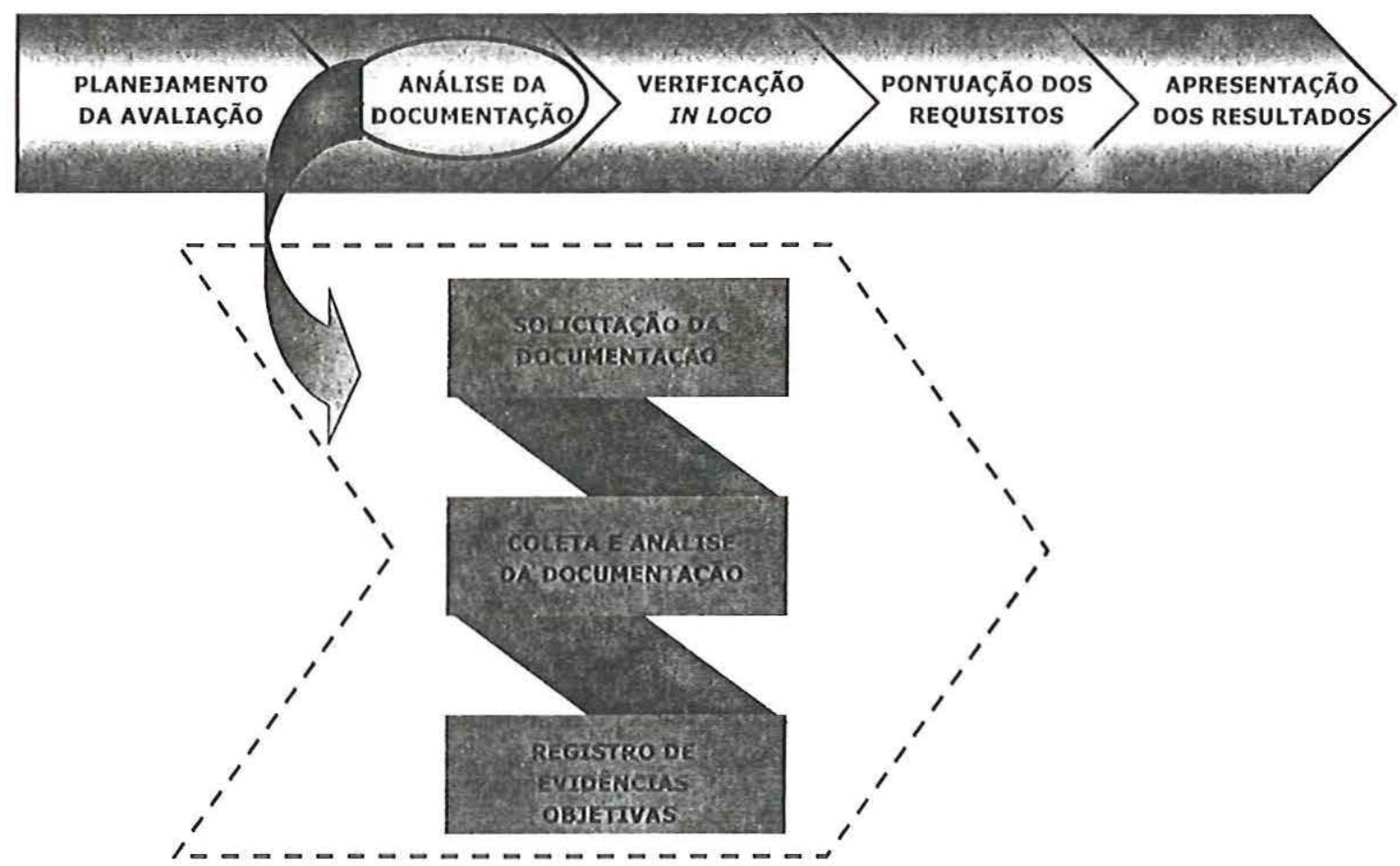

Figura 17 - Atividades ligadas à Análise da documentação.

A análise crítica de documentos tem como objetivo a determinação da adequação do sistema de gestão da qualidade da organização em relação aos requisitos de documentação ISO 9001:2000 e o reconhecimento dos padrões adotados pela organização, que são investigados a posteriori. Todos os documentos de trabalho devem ser retidos até a conclusão da avaliação e a sua disposição é estabelecida conforme acordo entre o avaliador e a alta direção da organização. Os documentos com informações confidenciais ou proprietárias devem ser salvaguardados adequadamente pelo avaliador.

Além da documentação analisada, esta etapa também envolve o controle de registros das atividades de avaliação, de forma a demonstrar a implementação do programa de avaliação. Estes registros incluem:

$>$ planos de avaliação;

$>$ relatórios de avaliação;

$>$ instrumento avaliatório contendo evidências objetivas; e

$>$ registros de competência dos avaliadores. 


\subsubsection{Passo 3 - Verificação in loco}

Este passo consiste na realização de entrevistas com os facilitadores e também no levantamento de informações a partir das constatações feitas nos processos avaliados. As informações e evidências objetivas apuradas devem ser registradas no instrumento avaliatório para posterior análise e pontuação. A Figura 18 ilustra as atividades pertinentes à verificação in loco.

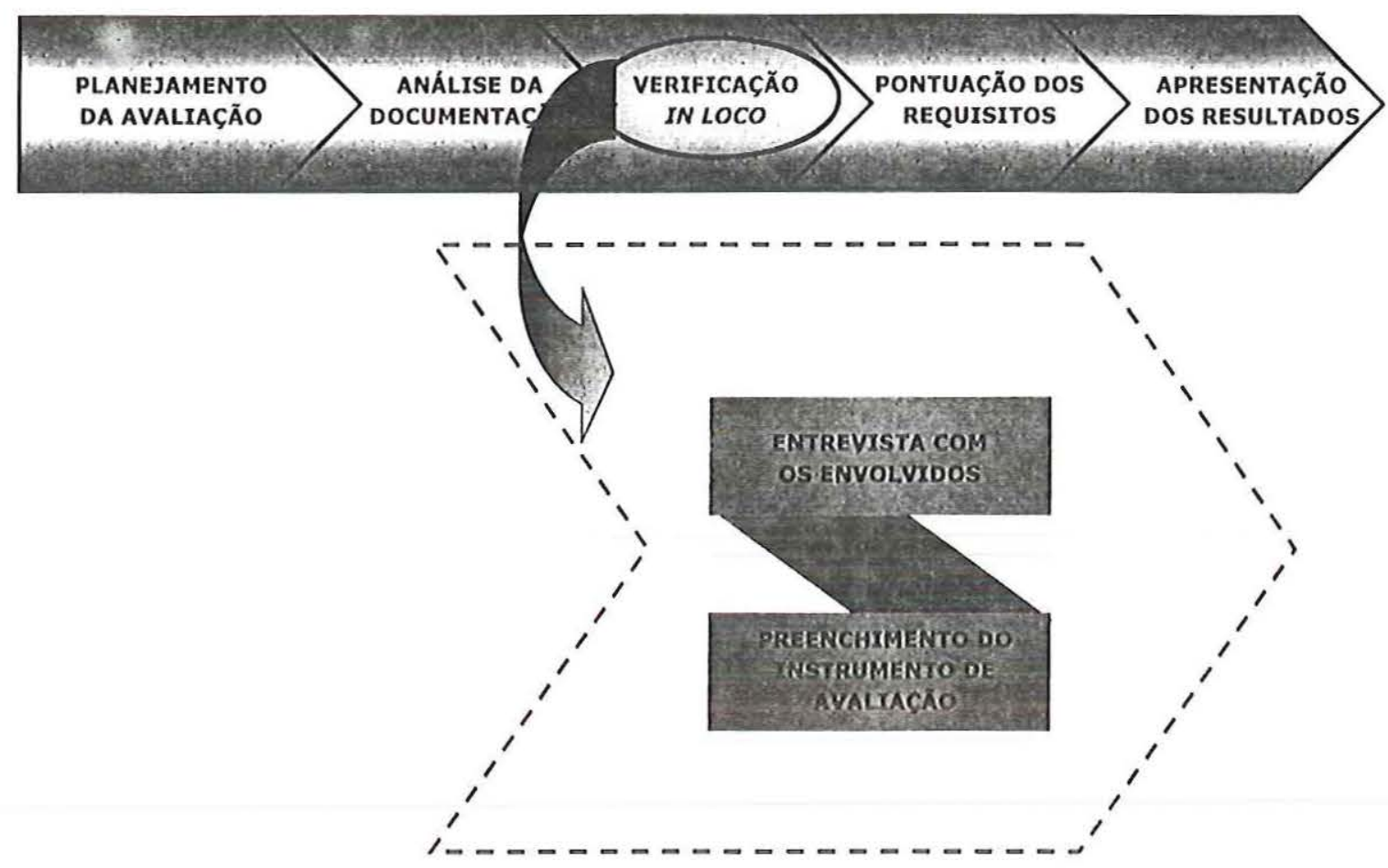

Figura 18 - Atividades ligadas à Condução da avaliação.

As informações coletadas durante a avaliação devem ser verificadas de modo a assegurar a sua validade. Todas as informações pertinentes aos aspectos de avaliação verificáveis são consideradas evidências objetivas. Antes de analisar as evidências objetivas deve-se primeiramente verificar a consistência das informações obtidas de modo a evitar a utilização de informações incoerentes e obsoletas, que possam comprometer a veracidade da situação atual da organização avaliada. Para atestar esta consistência, o avaliador deve descrever as evidências objetivas de forma detalhada, permitindo assim, o esclarecimento quanto ao atendimento dos aspectos de avaliação. A seção 3.2 fornece diretrizes para o preenchimento do instrumento avaliatório. 


\subsubsection{Passo 4 - Pontuação dos requisitos}

Este passo envolve a análise das informações e evidências objetivas apuradas nos passos 2 e 3, com o objetivo de estabelecer a pontuação dos requisitos estabelecidos no instrumento avaliatório. A Figura 19 ilustra as atividades referentes à pontuação dos requisitos.

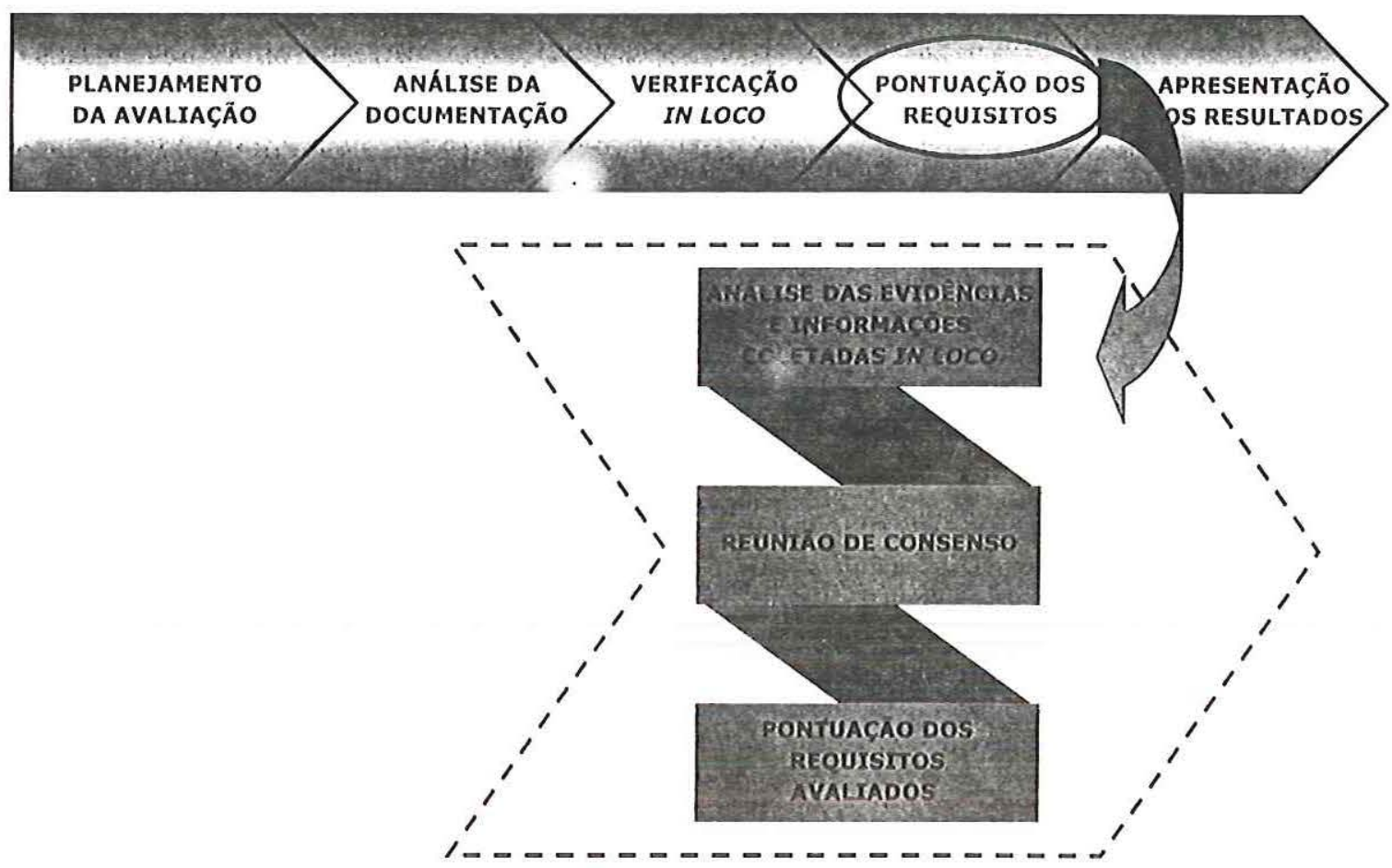

Figura 19 - Atividades ligadas à Pontuação dos requisitos.

Antes de estabelecer a pontuação final, o avaliador deve agrupar as evidências objetivas com o intuito de facilitar a compreensão da situação atual do sistema de gestão da qualidade da organização permitindo que o processo de consenso entre o avaliador e os avaliadores auxiliares seja realizado sem embate de interpretação.

A avaliação das evidências objetivas consiste na identificação do percentual estabelecido no instrumento avaliatório, de acordo com o estágio de adequação aos aspectos de avaliação. A soma dos percentuais obtidos em cada aspecto de avaliação resulta no percentual do item avaliado, que multiplicado pelo valor de pontuação máxima resulta no número de pontos obtidos por cada item. A soma de todos os itens gera a pontuação global, que permite a identificação do estágio atual do sistema de gestão da qualidade da organização avaliada contra os requisitos ISO 9001:2000. A seção 3.2 apresenta com detalhes o processo de pontuação. 


\subsubsection{Passo 5 - Apresentação dos resultados}

O último passo, envolve a elaboração do relatório final de avaliação abrangendo: considerações gerais; pontos fortes e oportunidades para melhoria em relação aos princípios de gestão; síntese de pontuação; e estágio atual de adequação aos requisitos ISO 9001:2000. O relatório final deve ser entregue à alta direção da organização durante a reunião de apresentação dos resultados, onde o avaliador faz algumas recomendações e comentários acerca do estágio atual de adequação aos requisitos ISO 9001:2000 em que a organização se encontra. A Figura 20 ilustra as atividades referentes à apresentação dos resultados.

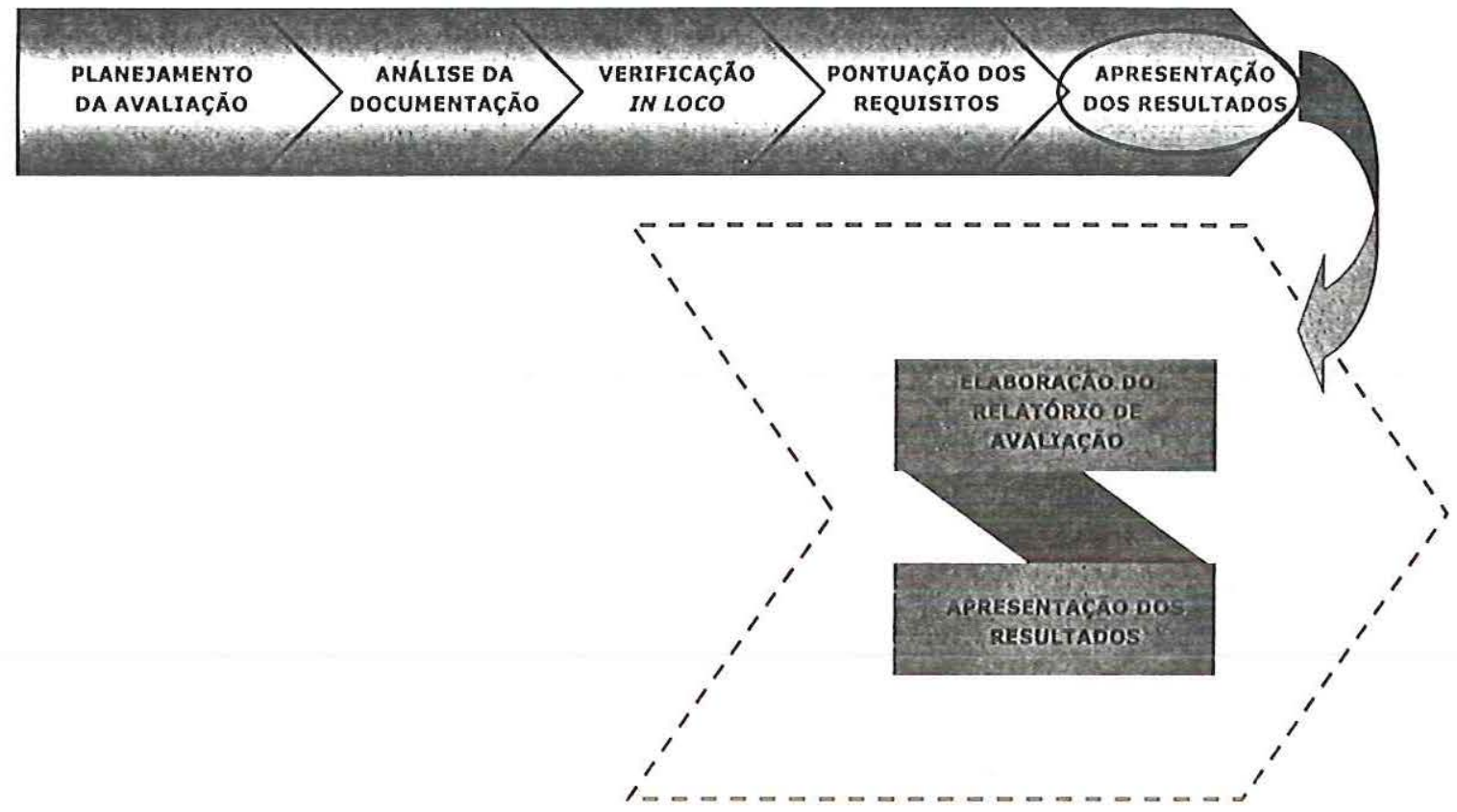

Figura 20 - Atividades ligadas à apresentação dos resultados.

Com base no relatório de avaliação, a organização pode identificar o grau de adequação aos requisitos ISO 9001:2000 ou o estágio de maturidade do sistema de gestão da qualidade segundo estes requisitos. A análise crítica dos resultados da avaliação permite o reconhecimento dos pontos fortes do sistema de gestão da qualidade da organização. Permite também, a identificação das oportunidades para melhoria, isto é, as lacunas existentes entre o sistema atual e os requisitos ISO 9001:2000. Desta forma, a organização avaliada pode melhorar seu sistema de gestão da qualidade com base no relatório final. Para tanto, planos de ação podem ser estabelecidos de modo a garantir a eficácia da implementação das ações. 


\subsection{Instrumento avaliatório}

Considerando os objetivos deste trabalho, a adoção de um instrumento simplificado capaz de permitir a avaliação do grau em que se encontra a organização em relação aos requisitos ISO 9001:2000 é de extrema relevância.

Neste sentido, a elaboração do instrumento avaliatório tem como referencial teórico, a publicação "Primeiros Passos para a Excelência: Critérios para o bom desempenho e diagnóstico da organização" da Fundação para o Prêmio Nacional da Qualidade (2002b). A sistemática de avaliação simplificada dos critérios de excelência foi adaptada para os requisitos ISO 9001:2000. Nesta adaptação foram considerados os seguintes aspectos:

dimensões e fatores de avaliação: ao contrário do que é estabelecido no modelo da Fundação para o Prêmio Nacional da Qualidade, onde são utilizadas três dimensões de avaliação (enfoque, aplicação e resultados), o instrumento de avaliação proposto leva em consideração apenas o fator adequação, ou seja, o atendimento ao requisito aplicável, considerando o perfil da organização;

sistemática de pontuação: o instrumento de avaliação proposto compartilha da mesma sistemática de pontuação estabelecida na edição Primeiros Passos. Entretanto, os valores percentuais, bem como a pontuação máxima obtida, foram adaptados para os requisitos ISO 9001:2000 levando em consideração os requisitos pontuais (aplicáveis a processos específicos) e os requisitos sistêmicos, ou seja, aplicáveis a todos os processos. Além disso, foi atribuído maior peso aos requisitos de documentação, tais como registros, manual da qualidade e procedimentos documentados;

estrutura dos itens: Na publicação Primeiros Passos, os sete critérios (liderança, estratégia e planos, clientes e sociedade, informações e conhecimento, pessoas, processos e resultados) estão subdivididos em vinte e seis itens de avaliação, sendo que, para os itens de enfoque e aplicação, os aspectos de 1 a 3 referem-se à definição execução das práticas de gestão, o aspecto 4 refere-se aos métodos de controle das práticas de gestão e o aspecto 5 refere-se ao aprendizado. Os itens de resultados são compostos por um único aspecto. No instrumento avaliatório proposto, os cinco capítulos da norma ISO 9001:2000 estão distribuídos em cinco seções e subdivididos em doze itens de avaliação. Desta forma, cada item possui cinco aspectos de 
avaliação que visam verificar a adequação da organização em relação aos requisitos pertinentes ao item avaliado. Ao todo são sessenta aspectos de avaliação que correspondem aos vinte e três requisitos da ISO 9001:2000, conforme apresentado na Figura 7, página 19. 


\subsubsection{Diretrizes para pontuação}

Esta seção descreve a sistemática de pontuação do instrumento de avaliação proposto. Os cinco capítulos da norma ISO 9001:2000 foram adaptados para doze itens de avaliação, que estão subdivididos em sessenta aspectos de avaliação. Cada item de avaliação possui cinco aspectos de avaliação que representam os requisitos normativos pertinentes a cada item. O Quadro 9 apresenta as seções, os itens e as pontuações máximas estabelecidas.

Quadro 9-Seções, itens e pontuação máxima

\begin{tabular}{|c|c|c|}
\hline Seção & |Itens & $\begin{array}{l}\text { Pontuação } \\
\text { máxima }\end{array}$ \\
\hline \multirow{2}{*}{$\begin{array}{l}\text { 3.3.1 Sistema de } \\
\text { gestão da qualidade }\end{array}$} & 3.3.1.I Requisitos gerais & 150 \\
\hline & 3.3.1.2 Requisitos de documentação & 150 \\
\hline 3.3.2 & 3.3.2.1 Comprometimento da direção, foco no cliente, política da & 100 \\
\hline Responsabilidade da & qualidade e planejamento & \\
\hline direção & $\begin{array}{l}\text { 3.3.2.2 Responsabilidade e autoridade, representante da direção, } \\
\text { comunicação interna e análise crítica pela direção }\end{array}$ & 100 \\
\hline \multirow[t]{2}{*}{$\begin{array}{l}3.3 .3 \text { Gestão de } \\
\text { recursos }\end{array}$} & $\begin{array}{l}\text { 3.3.3.1 Provisão de recursos, infra-estrutura e ambiente de } \\
\text { trabalho }\end{array}$ & 75 \\
\hline & 3.3.3.2 Recursos humanos & 75 \\
\hline \multirow[t]{4}{*}{$\begin{array}{l}\text { 3.3.4 Realização do } \\
\text { produto }\end{array}$} & $\begin{array}{l}\text { 3.3.4.I Planejamento da realização do produto e processos } \\
\text { relacionados a clientes }\end{array}$ & 45 \\
\hline & 3.3.4.2 Projeto de desenvolvimento & 20 \\
\hline & $\begin{array}{l}\text { 3.3.4.3 Aquisição e controle de dispositivos de medição e } \\
\text { monitoramento }\end{array}$ & 45 \\
\hline & 3.3.4.4 Realização do produto & 40 \\
\hline \multirow{2}{*}{$\begin{array}{l}\text { 3.3.5 Medição, análise } \\
\text { e melhoria }\end{array}$} & 3.3.5.1 Medição e monitoramento & 100 \\
\hline & $\begin{array}{l}\text { 3.3.5.2 Cont:ole de produto não-conforme, análise de dados e } \\
\text { melhorias }\end{array}$ & 100 \\
\hline \multicolumn{2}{|l|}{ Total de pontos possíveis } & 1000 \\
\hline
\end{tabular}

Conforme descrito no item 3.1.4, o avaliador, juntamente com os avaliadores auxiliares e de posse das evidências objetivas deve identificar o percentual que melhor representa a situação atual da organização em relação aos critérios de avaliação. $\mathrm{O}$ requerido em cada um dos aspectos de avaliação está descrito no estilo afirmativo, de modo a forçar a busca por evidências objetivas. A identificação do percentual para cada aspecto de avaliação é feita com base em uma escala de alternativas que representa uma condição de adequação aos critérios de avaliação e conseqüentemente ao grau de adequação ao requisito ISO 9001:2000 pertinente. O Quadro 10 apresenta a escala de alternativas do instrumento de avaliação proposto. 
Quadro 10 - Escalas de alternativas

\begin{tabular}{|c|l|}
\hline Escala de Alternativas \\
\hline $0 \%$ & $\begin{array}{l}\text { A afirmação não é sustentada pelas justificativas apresentadas, seja pela } \\
\text { inexistência de sistemáticas ou pela inadequação ao aspecto de avaliação. }\end{array}$ \\
\hline $10 \%$ & $\begin{array}{l}\text { A afirmação é parcialmente sustentada pelas justificativas apresentadas, } \\
\text { com algumas sistemáticas adequadas, porém, sem o total atendimento ao } \\
\text { aspecto de avaliação. }\end{array}$ \\
\hline $20 \%$ & $\begin{array}{l}\text { A afirmação é sustentada pelas justificativas apresentadas, com sistemáticas } \\
\text { adequadas ao aspecto de avaliação. }\end{array}$ \\
\hline
\end{tabular}

A alternativa escolhida deve ser justificada com base no registro de evidências objetivas que indica os pontos fortes e as oportunidades de melhoria em relação a cada item de avaliação. Estas informações devem ser registradas no verso da folha de pontuação do item avaliado. Um modelo de registro de evidências objetivas é ilustrado no Quadro 11.

O termo "justificativa" utilizado no instrumento de avaliação tem como objetivo apresentar as sistemáticas de gestão da qualidade adotadas pela organização, incluindo os responsáveis, os documentos utilizados, exemplos de práticas e outras informações relevantes encontradas nas evidências objetivas, permitindo assim, o esclarecimento quanto à nota atribuída aos aspectos de avaliação.

Cada um dos doze itens de avaliação é constituído de cinco aspectos de avaliação, os quais que devem ser pontuados de acordo com a escala de pontuação pertinente. Para obter o percentual total de um item deve-se somar os cinco valores percentuais de cada aspecto de avaliação. Assim, o completo atendimento dos cinco aspectos de avaliação, representa $100 \%$ de atendimento ao item avaliado. O percentual total obtido para cada item de avaliação pode variar entre $0 \%$ e $100 \%$ (sempre em múltiplos de 10). 
Quadro 11 - Registro de evidências objetivas

\begin{tabular}{|l|l|}
\hline \multicolumn{2}{|l|}{ Evidências objetivas } \\
\hline Pontos fortes \\
\hline $\begin{array}{l}\text { Aspectos de } \\
\text { Avalią̧ão }\end{array}$ & Justificativas \\
\hline & \\
\hline & \\
\hline & \\
\hline & \\
\hline Oportunidades para melhorias \\
\hline Aspectos de & Justificativas \\
\hline & \\
\hline & \\
\hline & \\
\hline
\end{tabular}

A multiplicação do percentual total de cada item pela pontuação máxima do item correspondente resulta na pontuação obtida para cada item avaliado. A pontuação global é o resultado da soma da pontuação obtida em cada um dos doze itens de avaliação. $\mathrm{O}$ completo atendimento aos itens de avaliação (100\% em todos os itens avaliados) consiste na pontuação máxima obtida, ou seja, 1000 pontos. O Quadro 12 apresenta a sintese da pontuação do instrumento de avaliação proposto.

Quadro 12 - Síntese da pontuação

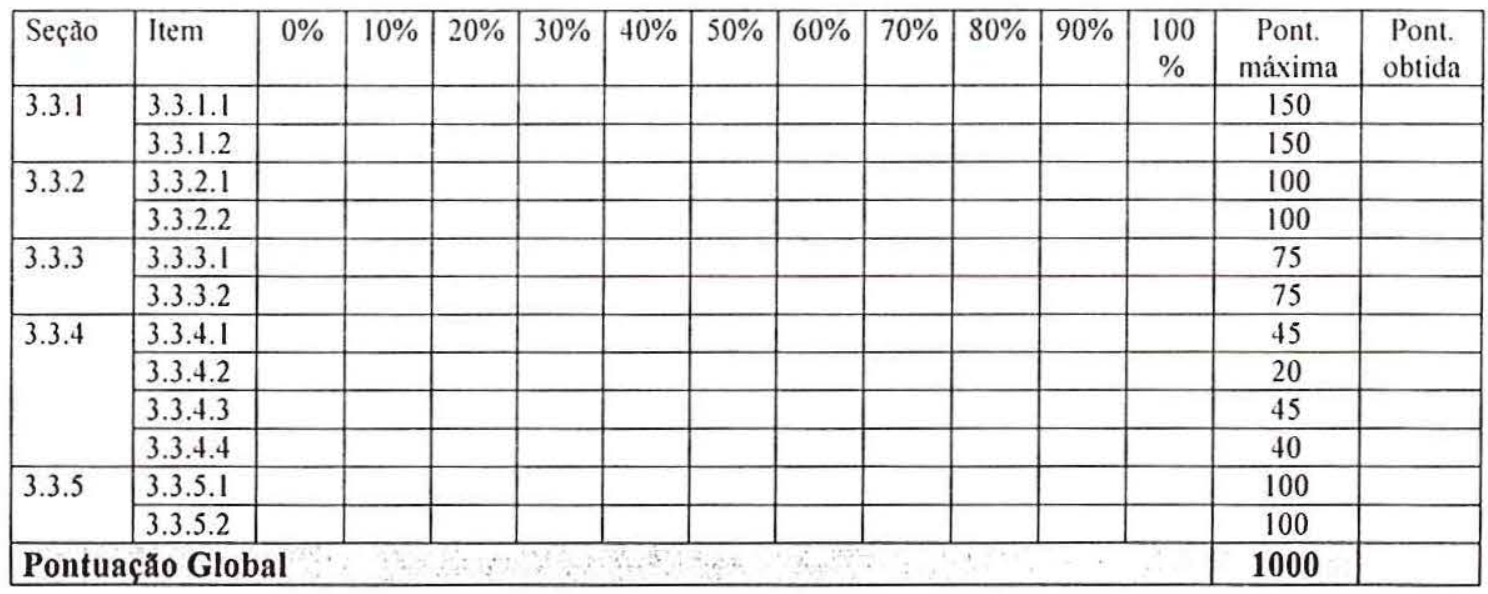


Com base na pontuação global obtida, a organização avaliada pode identificar o estágio atual de adequação aos requisitos ISO 9001:2000. Se a pontuação da organização chegar a 1000 pontos significa que as práticas de gestão da qualidade estão totalmente adequadas aos requisitos ISO 9001:2000. O Quadro 13 apresenta as faixas de pontuação correspondentes aos estágios que a organização se encontra quanto ao atendimento aos requisitos ISO 9001:2000.

Quadro 13 - Faixas de pontuação

\begin{tabular}{|c|c|c|c|}
\hline \multicolumn{3}{|c|}{ Faixa } & \multirow{2}{*}{ Estágio da Organização } \\
\hline $\mathrm{N}^{\circ}$ & Posição & Pontuação & \\
\hline 5 & $\begin{array}{l}\text { Média } \\
\text { Baixa }\end{array}$ & $\begin{array}{l}971-1000 \\
901-970\end{array}$ & $\begin{array}{l}\text { Total atendimento aos itens de avaliação. O sistema de gestão } \\
\text { da qualidade está aderente a norma ISO 9001:2000. }\end{array}$ \\
\hline 4 & $\begin{array}{l}\text { Alta } \\
\text { Média } \\
\text { Baixa }\end{array}$ & $\begin{array}{l}831-900 \\
761-830 \\
701-760\end{array}$ & $\begin{array}{l}\text { Muitas evidências de atendimento aos itens de avaliação. O } \\
\text { sistema de gestão da qualidade está parcialmente aderente aos } \\
\text { requisitos ISO 9001:2000. }\end{array}$ \\
\hline 3 & $\begin{array}{l}\text { Alta } \\
\text { Média } \\
\text { Baixa }\end{array}$ & $\begin{array}{l}631-700 \\
561-630 \\
501-560\end{array}$ & $\begin{array}{l}\text { Existem algumas lacunas importantes no atendimento aos itens } \\
\text { de avaliação. Boa parte dos processos atende aos requisitos } \\
\text { ISO } 9001: 2000 \text {. }\end{array}$ \\
\hline 2 & $\begin{array}{l}\text { Alta } \\
\text { Média } \\
\text { Baixa }\end{array}$ & $\begin{array}{l}431-500 \\
361-430 \\
301-360\end{array}$ & $\begin{array}{l}\text { Existem muitas lacunas significativas no atendimento aos itens } \\
\text { de avaliação. Começam a aparecer evidências de adequação } \\
\text { aos requisitos ISO 9001:2000. }\end{array}$ \\
\hline 1 & $\begin{array}{l}\text { Alta } \\
\text { Média } \\
\text { Baixa }\end{array}$ & $\begin{array}{c}201-300 \\
101-200 \\
0-100\end{array}$ & $\begin{array}{l}\text { Poucas evidências de atendimento aos itens de avaliação. Não } \\
\text { se pode considerar que o sistema de gestão da qualidade da } \\
\text { organização está aderente à norma ISO 9001:2000. }\end{array}$ \\
\hline
\end{tabular}




\subsection{Apresentação dos itens de avaliação}

\subsubsection{Sistema de gestão da qualidade}

\subsubsection{Requisitos gerais}

Aborda como a organização identifica e monitora os processos necessários ao sistema de gestão da qualidade, incluindo aqueles adquiridos externamente, desde que afetem a qualidade do produto em relação aos requisitos. Tais processos podem incluir aqueles referentes às atividades de gestão, provisão de recursos, realização do produto e medição.

\section{Quadro 14-Requisitos Gerais (150 pontos)}

\begin{tabular}{|c|c|c|c|}
\hline Aspectos de Avaliação & & ntuaçı & \\
\hline $\begin{array}{l}\text { A organização estabelece, documenta, implementa e mantém um sistema de gestão } \\
\text { da qualidade melhorando continuamente a sua eficácia com base na norma NBR } \\
\text { ISO } 9001: 2000 \text {. }\end{array}$ & $0 \%$ & $10 \%$ & $20 \%$ \\
\hline Justificativa & & & \\
\hline 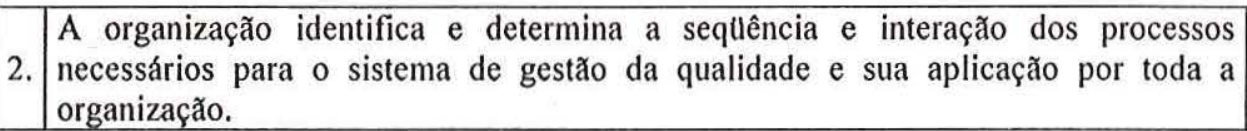 & $0 \%$ & $10 \%$ & $20 \%$ \\
\hline Justificativa & & & \\
\hline $\begin{array}{l}\text { 3. } \begin{array}{l}\text { Os critérios e métodos necessários para assegurar que a operação e o controle desses } \\
\text { processos sejam eficazes estão determinados. }\end{array} \\
\end{array}$ & $0 \%$ & $10 \%$ & $20 \%$ \\
\hline Justificativa & & & \\
\hline \begin{tabular}{l|l|} 
4. & $\begin{array}{l}\text { A organização disponibiliza os recursos e as informações necessárias para apoiar a } \\
\text { operação e o monitoramento desses processos. }\end{array}$
\end{tabular} & $0 \%$ & $10 \%$ & $20 \%$ \\
\hline Justificativa & & & \\
\hline \begin{tabular}{l|l} 
5. & A organização monitora, mede e analisa esses processos implementando açð̃es \\
necessárias para atingir os resultados planejados e a melhoria contínua desses \\
processos.
\end{tabular} & $0 \%$ & $10 \%$ & $20 \%$ \\
\hline Justificativa & & & \\
\hline Percentual do item & & & $\%$ \\
\hline
\end{tabular}




\subsubsection{Requisitos de documentação}

Aborda como a organização estabelece e controla os documentos pertinentes ao SGQ tais como procedimentos documentados, instruções de trabalho, documentos de origem externa, dados do sistema, registros e outros documentos necessários para assegurar a eficácia do SGQ. O termo "procedimento documentado" significa que o procedimento é estabelecido, documentado, implementado e mantido.

Quadro 15 - Requisitos de documentação (150 pontos)

\begin{tabular}{|c|c|c|c|c|}
\hline \multicolumn{2}{|c|}{ Aspectos de Avaliação } & \multicolumn{3}{|c|}{ Pontuação } \\
\hline 1. & $\begin{array}{l}\text { A documentação do sistema de gestão da qualidade da organização inclui } \\
\text { declaraçð̃es da política da qualidade e dos objetivos da qualidade, documentos } \\
\text { necessários para garantir a eficácia dos processos, manual da qualidade e registros e } \\
\text { procedimentos documentados requeridos. }\end{array}$ & $0 \%$ & $10 \%$ & $20 \%$ \\
\hline \multicolumn{5}{|c|}{ Justificativa } \\
\hline 2. & $\begin{array}{l}\text { A organização possui um manual da qualidade que descreve a interação entre os } \\
\text { processos e o escopo do sistema de gestão da qualidade, bem como os } \\
\text { procedimentos documentados estabelecidos ou referência a eles. }\end{array}$ & $0 \%$ & $10 \%$ & $20 \%$ \\
\hline \multicolumn{5}{|c|}{ Justificativa } \\
\hline 3. & $\begin{array}{l}\text { A organização possui um procedimento documentado que define os controles } \\
\text { necessários para os documentos do SGQ de modo a evitar o uso não intencional de } \\
\text { documentos obsoletos. Os documentos de origem externa são identificados e sua } \\
\text { distribuição é controlada. }\end{array}$ & $0 \%$ & $10 \%$ & $20 \%$ \\
\hline \multicolumn{5}{|c|}{ Justificativa } \\
\hline 4. & $\begin{array}{l}\text { A organização assegura que os registros são mantidos legiveis, prontamente } \\
\text { identificáveis e recuperáveis, de modo a prover evidências da conformidade com } \\
\text { requisitos e da operação eficaz do SGQ. }\end{array}$ & $0 \%$ & $10 \%$ & $20 \%$ \\
\hline \multicolumn{5}{|c|}{ Justificativa } \\
\hline & $\begin{array}{l}\text { A organização possui um procedimento documentado que define os controles } \\
\text { necessários para os registros. }\end{array}$ & $0 \%$ & $10 \%$ & $20 \%$ \\
\hline \multicolumn{5}{|c|}{ Justificativa } \\
\hline \multirow{2}{*}{\multicolumn{5}{|c|}{$\begin{array}{l}\text { Obs.1: o escopo do sistema de gestão da qualidade deve incluir, quando aplicável os detalhes e } \\
\text { justificativas para quaisquer exclusð̃es. } \\
\text { Obs.2: Os controles necessários para os documentos do SGQ devem abranger: aprovação, antes de sua } \\
\text { emissão; análise crítica e reaprovação; identificação da situação atual, disponibilidade de versð̃es atuais } \\
\text { nos locais de uso e legibilidade. }\end{array}$}} \\
\hline & & & & \\
\hline \multicolumn{5}{|c|}{$\begin{array}{l}\text { Obs.3: Registros são um tipo especial de documentos e seu controle deve contemplar identificação, } \\
\text { armazenamento, proteção, recuperação, tempo de retenção e descarte. }\end{array}$} \\
\hline
\end{tabular}




\subsubsection{Responsabilidade da direção}

\subsubsection{Comprometimento da direção, foco no cliente, política da qualidade e planejamento.}

Aborda como a organização evidencia seu comprometimento com o SGQ incluindo o seu desenvolvimento, implantação e melhoria contínua de sua eficácia. Busca evidenciar como os objetivos da qualidade, incluindo aqueles relacionados ao desenvolvimento do produto, são estabelecidos.

Quadro 16 - Comprometimento da direção, foco no cliente, política da qualidade e planejamento (100 pontos)

\begin{tabular}{|c|c|c|c|}
\hline Aspectos de Avaliação & \multicolumn{3}{|c|}{ Pontuação } \\
\hline $\begin{array}{l}\text { A organização evidencia seu comprometimento com o SGQ através da política da } \\
\text { qualidade, dos objetivos da qualidade, da condução de análises críticas pela Alta } \\
\text { Direção, da disponibilidade de recursos e da comunicação sobre o atendimento aos } \\
\text { requisitos pertinentes. }\end{array}$ & $0 \%$ & $10 \%$ & $20 \%$ \\
\hline \multicolumn{4}{|l|}{ Justificativa } \\
\hline \begin{tabular}{l|l} 
2. & $\begin{array}{l}\text { A organização assegura que os requisitos do cliente são determinados e atendidos } \\
\text { visando o aumento da satisfação do cliente. }\end{array}$ \\
\end{tabular} & $0 \%$ & $10 \%$ & $20 \%$ \\
\hline \multicolumn{4}{|l|}{ Justificativa } \\
\hline $\begin{array}{l}\text { A política da qualidade é apropriada aos objetivos da organização e inclui o } \\
\text { comprometimento ao atendimento dos requisitos e à melhoria contínua do SGQ. Sua } \\
\text { estrutura é analisada criticamente e comunicada e entendida por toda a organização. }\end{array}$ & $0 \%$ & $10 \%$ & $20 \%$ \\
\hline \multicolumn{4}{|l|}{ Justificativa } \\
\hline 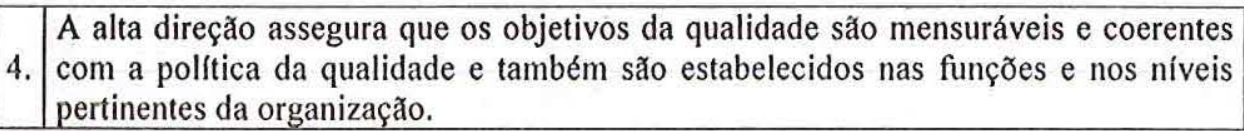 & $0 \%$ & $10 \%$ & $20 \%$ \\
\hline \multicolumn{4}{|l|}{ Justificativa } \\
\hline $\begin{array}{l}\text { 5. A organização assegura que o planejamento do SGQ é realizado levando em } \\
\text { consideração os requisitos pertinentes aos processos do SGQ e os objetivos da } \\
\text { qualidade. A integridade do SGQ é mantida quando mudanças são planejadas e } \\
\text { implementadas. }\end{array}$ & $0 \%$ & $10 \%$ & $20 \%$ \\
\hline \multicolumn{4}{|l|}{ Justificativa } \\
\hline Percentual do item & & & $\%$ \\
\hline
\end{tabular}




\subsubsection{Responsabilidade e autoridade, representante da direção, comunicação interna e análise crítica pela direção.}

Aborda como a organização estabelece e comunica as responsabilidades e autoridades incluindo aquelas relacionadas ao representante da direção. Aborda também a condução de análises críticas do SGQ com o objetivo de assegurar sua contínua pertinência, adequação e eficácia.

Quadro 17 - Responsabilidade e autoridade, Representante da direção, Comunicação interna e Análise Crítica pela Direção (100 pontos)

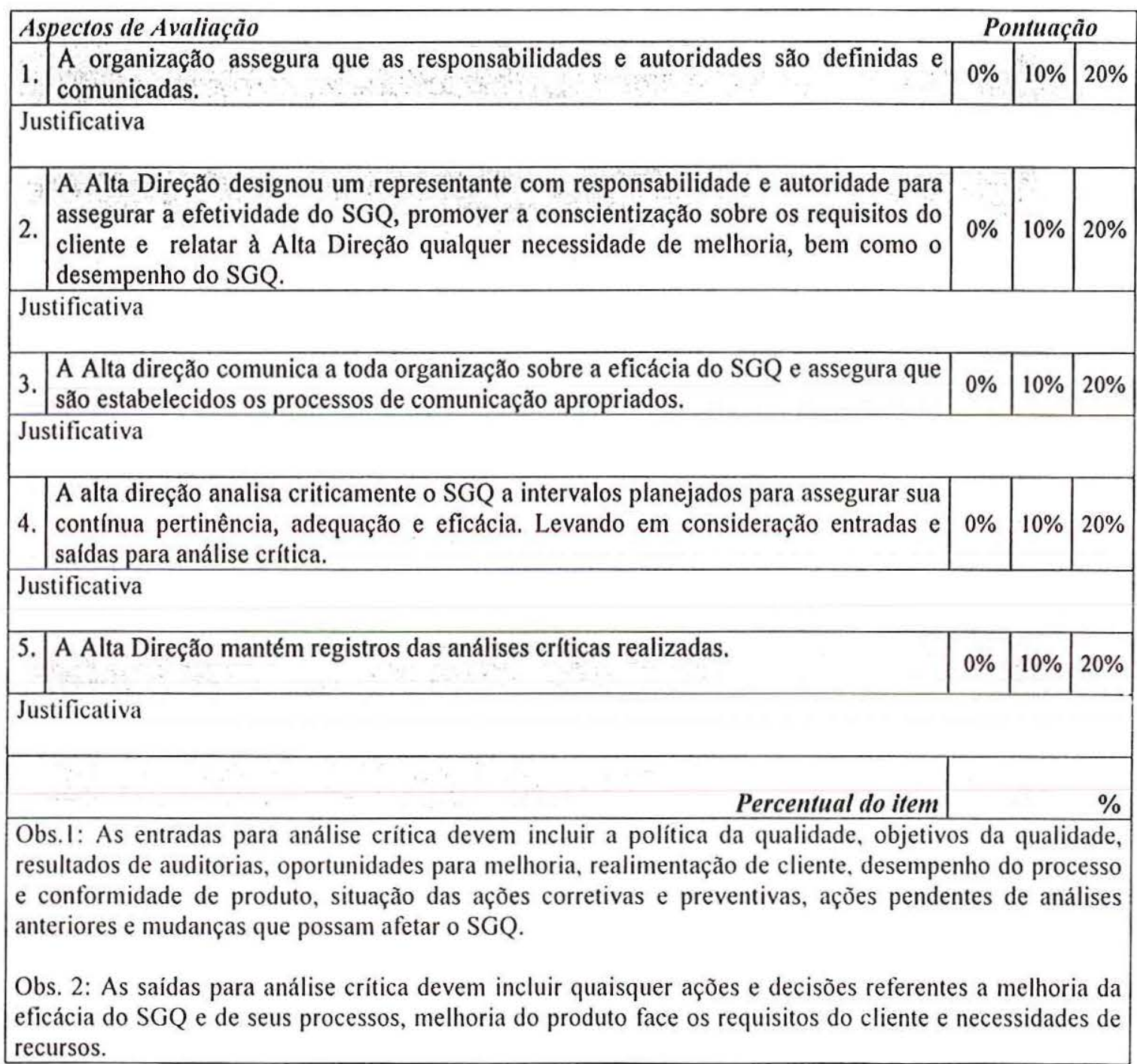




\subsubsection{Gestão de recursos}

\subsubsection{Provisão de recursos, Infra-estrutura e ambiente de trabalho}

Aborda como a organização provê os recursos necessários ao sistema de gestão da qualidade incluindo a infra-estrutura e as condições necessárias ao ambiente de trabalho.

Quadro 18 - Provisão de recursos, Infra-estrutura e ambiente de trabalho (75 pontos)

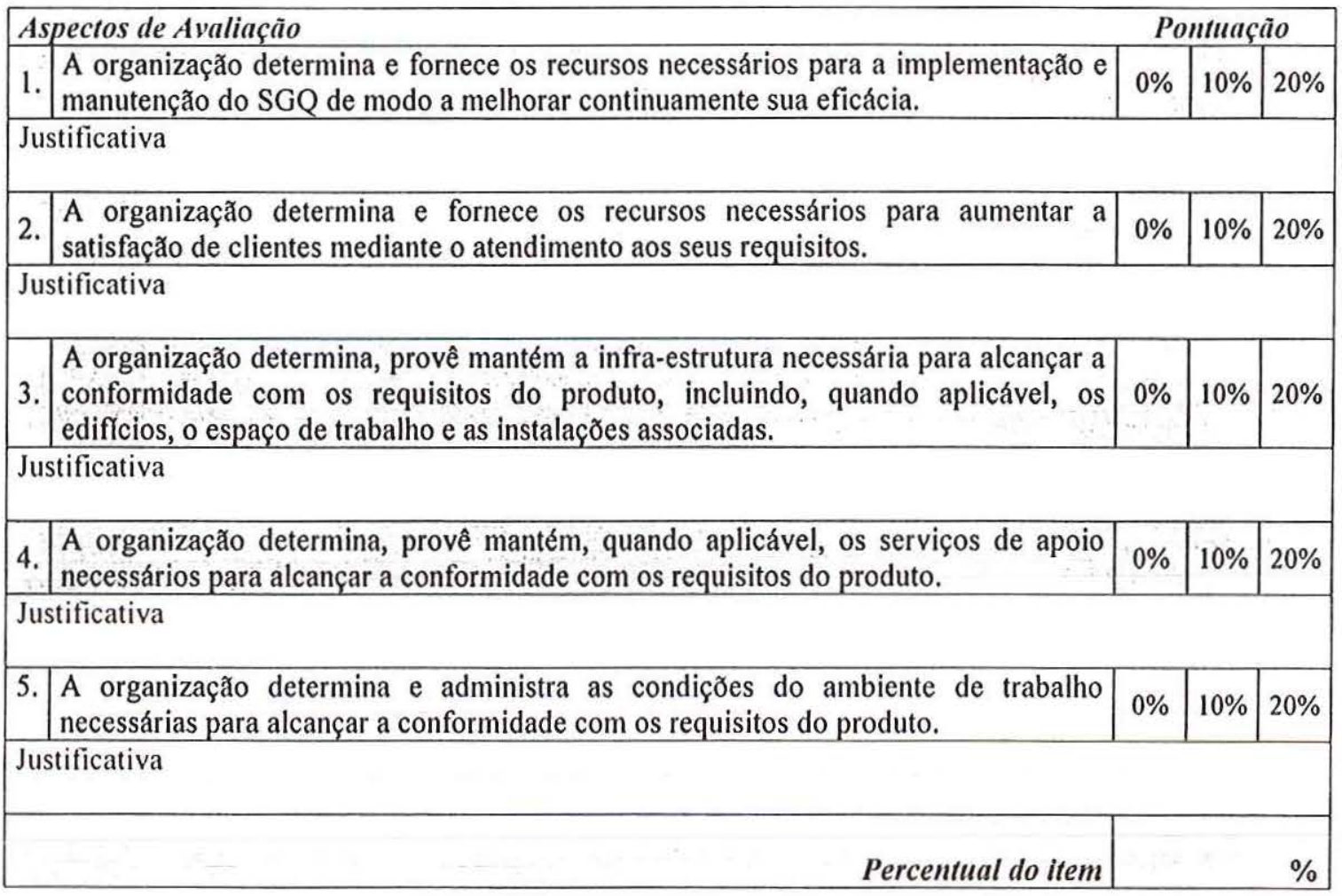




\subsubsection{Recursos humanos}

Aborda como a organização assegura a competência necessária às pessoas que executam atividades que afetam a qualidade do produto, bem como a conscientização quanto ao atendimento dos objetivos da qualidade.

Quadro 19 - Recursos humanos (75 pontos)

\begin{tabular}{|c|c|c|c|c|}
\hline \multicolumn{2}{|c|}{ Aspectos de Avaliação } & \multicolumn{3}{|c|}{ Pontuação } \\
\hline 1. & $\begin{array}{l}\text { As pessoas que executam atividades que afetam a qualidade do produto são } \\
\text { competentes, com base em educação, treinamento e experiência apropriados. }\end{array}$ & $0 \%$ & $10 \%$ & $20 \%$ \\
\hline \multicolumn{5}{|c|}{ Justificativa } \\
\hline 2. & $\begin{array}{l}\text { As competências necessárias para as pessoas que executam trabalhos que afetam a } \\
\text { qualidade do produto são determinadas pela organização. }\end{array}$ & $0 \%$ & $10 \%$ & $20 \%$ \\
\hline \multicolumn{5}{|c|}{ Justificativa } \\
\hline 3. & $\begin{array}{l}\text { A organização fornece treinamento ou realiza outras açб̃es para satisfazer as } \\
\text { necessidades de competência e avalia a eficácia das açôes executadas. }\end{array}$ & $0 \%$ & $10 \%$ & $20 \%$ \\
\hline \multicolumn{5}{|c|}{ Justificativa } \\
\hline 4. & $\begin{array}{l}\text { A organização assegura que o seu pessoal está consciente quanto à pertinência e } \\
\text { importância de suas atividades e de como elas contribuem para atingir os objetivos } \\
\text { da qualidade. }\end{array}$ & $0 \%$ & $10 \%$ & $20 \%$ \\
\hline \multicolumn{5}{|c|}{ Justificativa } \\
\hline 5. & $\begin{array}{l}\text { A organização mantém registros apropriados de educação, treinamento, habilidade e } \\
\text { experiência. }\end{array}$ & $0 \%$ & $10 \%$ & $20 \%$ \\
\hline \multicolumn{5}{|c|}{ Justificativa } \\
\hline & Percentual do item & & & \\
\hline
\end{tabular}




\subsubsection{Realização do produto}

\subsubsection{Planejamento da realização do produto e processos relacionados a clientes}

Aborda como a organização realiza o planejamento da realização do produto levando em consideração os requisitos estabelecidos pelo cliente, bem como aqueles estabelecidos pela organização.

Quadro 20 - Planejamento da realização do produto e processos relacionados a clientes (45 pontos)

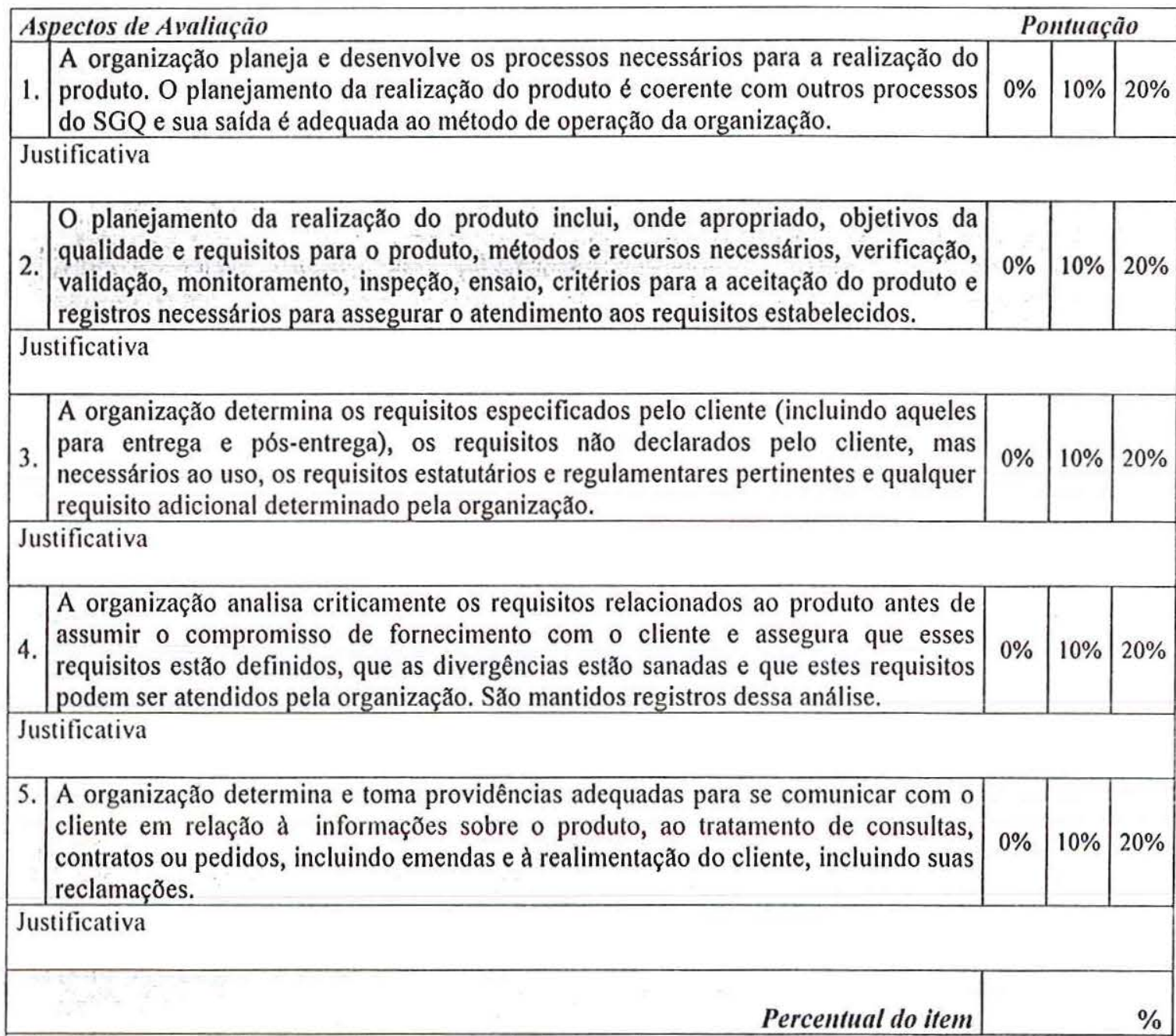

Obs. 1: Quando o cliente não fornecer uma declaração documentada dos requisitos, a organização deve confirmar os requisitos do cliente antes da aceitação. 


\subsubsection{Projeto e desenvolvimento}

Aborda como a organização planeja e controla o projeto e desenvolvimento de produto durante todas as etapas, de modo a assegurar que o produto resultante atende aos requisitos especificados.

Quadro 21 - Projeto e desenvolvimento (20 pontos)

\begin{tabular}{|l|l|l|l|l|}
\hline Aspectos de Avaliação & $\begin{array}{l}\text { Pontuação } \\
\text { 1. organização planeja e controla o projeto e desenvolvimento de produto } \\
\text { determinando seus estágios, incluindo análise crítica, verificação e validação, bem } \\
\text { como as responsabilidade e autoridades. São mantidos registros das entradas e } \\
\text { saídas de projeto e desenvolvimento. }\end{array}$ & $0 \%$ & $10 \%$ & $20 \%$ \\
\hline
\end{tabular}
Justificativa

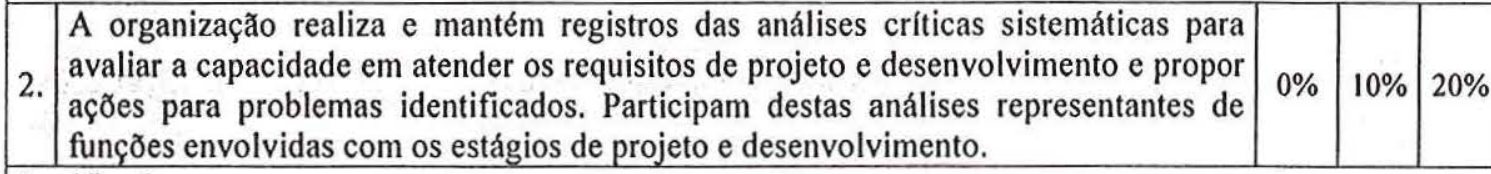
Justificativa

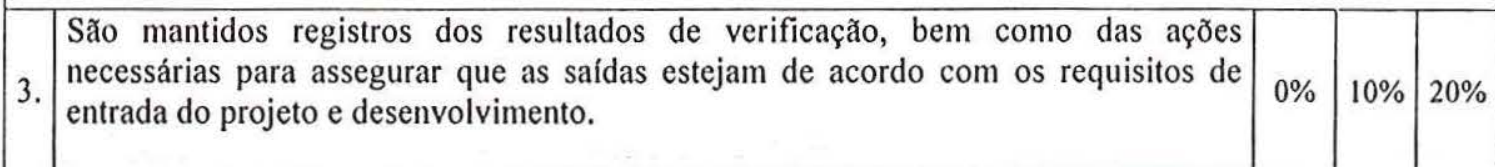

Justificativa

A validação do projeto é executada conforme disposiçð̃es planejadas para assegurar 4. que o produto resultante atende aos requisitos especificados. São mantidos registros 4. dos resultados de validação e das açð̃es pertinentes. Quando aplicável, a validação é concluída antes da entrega ou implementação do produto. Justificativa

5. A organização verifica, analisa criticamente, valida e aprova as alteraçð̃es antes de sua implementação. São mantidos registros destas análises, incluindo a avaliação do efeito das alteraçð̃es em partes componentes e no produto já entregue, bem como das ações pertinentes.

Justificativa

Percentual do item

Obs.1: As entradas de projeto e desenvolvimento devem ser determinadas e analisadas criticamente quanto à adequação devendo incluir os requisitos de funcionamento e de desempenho, os requisitos estatutários e regulamentares, informações de projetos semelhantes e outros requisitos aplicáveis.

Obs.2: As saidas de projeto e desenvolvimento devem ser atualizadas, aprovadas antes de serem liberadas e apresentadas de modo a permitir o atendimento aos requisitos de entrada para projeto e desenvolvimento. Devem também fornecer informações para aquisição, produção e fornecimento de serviço, conter critérios de aceitação e especificar as características necessárias ao produto. 


\subsubsection{Aquisição e controle de dispositivos de medição e monitoramento}

Aborda como a organização assegura que o produto adquirido está conforme os requisitos de aquisição, como são controlados os fornecedores e os produtos adquiridos levando em consideração o efeito do produto adquirido nos processos de realização e no produto final. Aborda também como a organização assegura a eficácia dos processos mediante o controle dos dispositivos de medição e monitoramento.

Quadro 22 - Aquisição e controle de dispositivos de medição e monitoramento (45 pontos) Aspectos de Avaliação

A organização estabelece critérios para seleção, avaliação e reavaliação para avaliar

1. e selecionar seus fornecedores com base na sua capacidade em fornecer produtos de 1. acordo com os requisitos especificados pela organização. São mantidos registros dessas avaliações, bem como das ações pertinentes.

Justificativa

As informações de aquisição descrevem o produto a ser adquirido e incluem, onde

2. apropriado, aprovação do produto, procedimentos e equipamento, qualificação de pessoal e sistema de gestão da qualidade. A organização assegura a adequação dos requisitos de aquisição antes da sua comunicação ao fornecedor.

Justificativa

3. A organização estabelece e implementa inspeção ou outras atividades necessárias

3. para assegurar que o produto adquirido atende aos requisitos especificados.

Pontuação

Justificativa

A organização determina as medições e monitoramento a serem realizados, bem

4. como os dispositivos de medição e monitoramento necessários para demonstrar a

4. conformidade do produto. Processos são estabelecidos para viabilizar a medição e monitoramento.

Justificativa

5. Quando constatado que o dispositivo não está conforme os requisitos, a organização avalia e registra a validade dos reśultados de medições anteriores. A organização toma ação apropriada no dispositivo, bem como em qualquer produto afetado. São mantidos registros dos resultados de calibração e verificação.

Justificativa

\section{Percentual do item}

Nota 1: Quando a organização ou seu cliente executar a verificação nas instalações do fornecedor, a organização deverá declarar, nas informações de aquisição, as providências de verificação pretendidas, bem como o método de liberação do produto.

Nota 2: Quando for necessário assegurar resultados válidos, os dispositivos de medição utilizados deverão ser ajustados ou reajustados, identificados (para determinar a situação da calibração), protegido contra ajustes que possam invalidar os resultados obtidos e protegido de dano e deterioração durante o manuseio, manutenção e armazenamento.

Nota 3: Quando for utilizado software de computador na medição e monitoramento de requisitos especificados, sua capacidade deve ser confirmada antes do uso inicial (e reconfirmada, quando necessário) para satisfazer a aplicação pretendida. 


\subsubsection{Realização do produto}

Aborda como a organização controla o planejamento e a realização da produção e fornecimento de serviço através da validação, rastreabilidade e identificação do produto ao longo da realização e preservação da propriedade do cliente e do produto final.

Quadro 23 - Realização do produto (40 pontos)

\begin{tabular}{|c|c|c|c|c|}
\hline \multicolumn{2}{|c|}{ Aspectos de Avaliação } & \multicolumn{3}{|c|}{ Pontuação } \\
\hline & $\begin{array}{l}\text { A organização planeja e realiza a produção e o fornecimento de serviço sob } \\
\text { condições controladas. }\end{array}$ & $0 \%$ & $10 \%$ & $20 \%$ \\
\hline \multicolumn{5}{|c|}{ Justificativa } \\
\hline 2. & $\begin{array}{l}\text { A organização valida os processos de produção e fornecimento de serviço onde a } \\
\text { salda resultante não possa ser verificada através de medição e monitoramento. A } \\
\text { validação demonstra a capacidade dos processos (incluindo aqueles onde anomalias } \\
\text { só fiquem aparentes após a entrega) de alcançar os resultados planejados. }\end{array}$ & $0 \%$ & $10 \%$ & $20 \%$ \\
\hline \multicolumn{5}{|c|}{ Justificativa } \\
\hline 3. & $\begin{array}{l}\text { A organização identifica a situação do produto quanto aos requisitos de } \\
\text { monitoramento e medição. Quando a rastreabilidade é um requisito, a organização } \\
\text { controla e identifica unicamente o produto. }\end{array}$ & $0 \%$ & $10 \%$ & $20 \%$ \\
\hline \multicolumn{5}{|c|}{ Justificativa } \\
\hline 4. & $\begin{array}{l}\text { A organização identifica, verifica, protege e salvaguarda a propriedade do cliente } \\
\text { (incluindo capital intelectual) fornecida para uso ou para incorporação ao produto. } \\
\text { Caso a propriedade do cliente for perdida, danificada ou considera inadequada, a } \\
\text { organização mantém registros dessa situação e comunica o cliente. }\end{array}$ & $0 \%$ & $10 \%$ & $20 \%$ \\
\hline \multicolumn{5}{|c|}{ Justificativa } \\
\hline & $\begin{array}{l}\text { A organização preserva a conformidade do produto, bem como suas partes } \\
\text { constituintes durante o processo interno incluindo o manuseio, a embalagem, o } \\
\text { armazenamento e a proteção e também entrega o produto no destino pretendido. }\end{array}$ & $0 \%$ & $10 \%$ & $20 \%$ \\
\hline \multicolumn{5}{|c|}{ Justificativa } \\
\hline & Percentual do item & & & $\%$ \\
\hline \multirow{2}{*}{\multicolumn{5}{|c|}{$\begin{array}{l}\text { Obs.1: Condições controladas devem incluir, quando aplicável, a disponibilidade de informações que } \\
\text { descrevam as caracteristicas do produto, a disponibilidade de instruções de trabalho, o uso de } \\
\text { equipamento adequado, disponibilidade, e uso de dispositivos de medição e monitoramento, bem como } \\
\text { sua implementação e a implementação da liberação, entrega e atividades pós-entrega. } \\
\text { Obs.2: A validação dos processos deve incluir, quando aplicável, os critérios definidos para análise crítica } \\
\text { e aprovação dos processos, a aprovação de equipamento e qualificação do pessoal, o uso de métodos e } \\
\text { procedimentos especificos, os requisitos para registros e a revalidação. }\end{array}$}} \\
\hline & & & & \\
\hline \multicolumn{5}{|c|}{$\begin{array}{l}\text { Obs.3: Em alguns setores de atividade, a gestão de configuração é um meio pelo qual a identificação e } \\
\text { rastreabilidade são mantidas. }\end{array}$} \\
\hline
\end{tabular}




\subsubsection{Medição, análise e melhoria}

\subsubsection{Medição e monitoramento}

Aborda como a organização planeja e implementa os processos necessários de medição e monitoramento para demonstrar a conformidade do produto e assegurar a conformidade do sistema de gestão da qualidade incluindo a determinação de métodos aplicáveis, como por exemplo, técnicas estatísticas.

Quadro 24 - Medição e monitoramento (100 pontos)

Aspectos de Avaliação

1. A organização determina os métodos para obtenção e uso das informações relativas

1. à percepção do cliente quanto ao atendimento aos seus requisitos.

\begin{tabular}{l|l|l|}
$0 \%$ & $10 \%$ & $20 \%$ \\
\hline
\end{tabular}

Justificativa

A organização executa auditorias internas a intervalos planejados, para verificar se o

2. SGQ está mantido e implementado eficazmente, conforme com os requisitos do $0 \%$ produto, com os requisitos internos e com os requisitos normativos ISO 9001:2000.

Justificativa

\begin{tabular}{l|l}
\hline A organização possui procedimento documentado definindo as responsabilidades e \\
os requisitos para o programa de auditorias internas. Os critérios de auditoria,
\end{tabular}

3. escopo, frequência e método estão definidos no programa e os registros são mantidos.

Justificativa

A organização utiliza métodos adequados para monitoramento de modo a

4. comprovar a capacidade dos processos em alcançar os resultados planejados.

Quando os resultados planejados não são alcançados a organização executa açð̃es para assegurar a conformidade do produto.

Justificativa

5. A organização mede e monitora as características do produto para verificar o \begin{tabular}{ll|l|l|l} 
atendimento aos seus requisitos e assegurar que providências planejadas foram & $0 \%$ & $10 \%$ & $20 \%$
\end{tabular} satisfeitas.Os registros indicam as pessoas autorizadas a liberar o produto.

Justificativa

Percentual do item

$\%$

Obs. I: O programa de auditoria deve ser estabelecido de modo a assegurar objetividade e imparcialidade.

Obs.2: A organização deve assegurar que as ações sejam implementadas sem a demora indevida e que os resultados dessas ações sejam verificados nas atividades de acompanhamento. 


\subsubsection{Controle de produto não-conforme, análise de dados e melhorias}

Aborda como a organização controla os produtos não-conformes e também como a organização melhora continuamente a eficácia do sistema de gestão da qualidade.

Quadro 25 - Controle de produto não-conforme, análise de dados e melhorias (100 pontos)

\begin{tabular}{|c|c|c|c|c|}
\hline As & Dectos de Avaliação & & Ituaç & \\
\hline 1. & $\begin{array}{l}\text { A organização possui um procedimento documentado que define os controles, as } \\
\text { responsabilidades e autoridades para garantir que os produtos não-conformes sejam } \\
\text { identificados, controlados e, quando corrigidos, reverificados. Registros destes } \\
\text { controles são mantidos. }\end{array}$ & $0 \%$ & $10 \%$ & $20 \%$ \\
\hline
\end{tabular}
Justificativa

A organização determina e analisa dados apropriados incluindo aqueles obtidos do

2 monitoramento, das mediçð̃es e de outras fontes pertinentes para demonstrar a

2. adequação e eficácia do SGQ, bem como avaliar oportunidades para a melhoria contínua.

Justificativa

A organização fornece evidências de melhoria contínua do SGQ através da política

3. da qualidade, objetivos da qualidade, análise de dados, açø̃es corretivas preventivas e análise critica pela direção.

Justificativa

4. A organização possui um procedimento que define ações corretivas para eliminar as 4. causas de não-conformidade, de forma a evitar sua repetição. Justificativa

5. A organização possui um procedimento que define açðes preventivas para eliminar as não-conformidades potenciais, de forma a evitar sua ocorrência.

Justificativa

Percentual do item

Obs.1: O controle dos produtos não-conformes deve incluir, onde apropriado, a execução de ações para eliminar a não-conformidade encontrada, a autorização do status do produto por autoridade pertinente ou pelo cliente, e a execução de ação para impedir o seu uso pretendido ou aplicação originais. Quando a não conformidade do produto for detectada após a entrega, a organização deve tomas as ações apropriadas à natureza da nào-conformidade.

Obs.2: O procedimento para ações corretivas deve definir os requisitos para análise crítica da nãoconformidade, determinação de suas causas, avaliação da necessidade de ações para garantir a não reincidência da não-conformidades. determinação e implementação de ações necessárias, registro dos resultados de ações executadas e análise critica das ações corretivas executadas.

Obs.3: O procedimento para ações preventivas deve definir os requisitos para definição de nãoconformidades potenciais e suas causas, avaliação da necessidade de ações para evitar a ocorrència de não-conformidades, definição e implementação de ações necessárias e registro dos resultados de ações executadas e análise crítica das ações preventivas executadas. 


\section{APLICAÇÃO DA PROPOSTA}

Este Capítulo apresenta a aplicação da proposta em empresas reais, em diferentes estágios de adequação aos requisitos ISO 9001:2000. O Capítulo inicia-se com uma apresentação do perfil de cada organização e sua trajetória na gestão da qualidade. A seguir, apresenta-se a pontuação obtida, os pontos fortes e as oportunidades para melhoria de cada empresa avaliada, considerando os princípios de gestão inerentes aos requisitos ISO 9001:2000. Por fim, apresenta-se uma análise global dos resultados obtidos.

\subsection{Apresentação das Empresas}

As empresas avaliadas foram selecionadas levando em consideração os objetivos estabelecidos neste estudo, ou seja, a proposição de um processo capaz de avaliar as práticas de gestão da qualidade de uma organização em relação ao estágio de adequação aos requisitos normativos ISO 9001:2000. Neste sentido, a aplicação deve ser viável a qualquer tipo de organização, independente de seu porte ou setor de atuação, seja ela certificada ou não na norma ISO 9001:2000. Entretanto, para viabilizar a aplicação do processo, foram considerados os seguintes aspectos:

que a empresa fosse localizada no interior do estado de São Paulo;

que a empresa desejasse receber uma avaliação de suas práticas relacionadas a gestão da qualidade em relação aos requisitos ISO 9001:2000 com o intuito de melhorar seu sistema de gestão;

que fossem analisadas empresas de setores diferenciados e que envolvesse tanto operações de manufatura como de serviços.

Para efeito de preservação da confidencialidade das informações pertinentes, as empresas avaliadas não serão identificadas. Além disso, ao iniciar os trabalhos, o pesquisador assumiu um compromisso de resguardar as informações coletadas e preservar a identificação dessas organizações. Deste modo, tais organizações serão reconhecidas doravante por empresas: "A", "B", "C", "D" e "E". 
A "empresa A" está localizada em Araraquara, Estado de São Paulo, onde foi fundada em 1965. Além de seu quadro de funcionários que atualmente conta com cinqüenta e seis colaboradores, a empresa possui aproximadamente cinco mil revendedores que atuam no Brasil e no mercado externo para onde exporta. Possui também uma rede de assistência técnica capacitada para atender a todos os distribuidores e consumidores de seus produtos. A empresa atua no setor metalúrgico e possui uma ampla linha de produtos incluindo bombas de graxa e de óleo, carregadores de bateria, correias industriais, máquinas de solda, mangueiras industriais, para-choques de máquinas agrícolas, além de uma diversificada linha de peças e ferramentas.

Atualmente, a "empresa A" vem direcionando seus esforços na redução de produtos não-conformes e, para isso, nos últimos anos foram padronizados os principais processos de realização do produto. Além disso, a organização adota uma filosofia de produção enxuta para melhor gerir os niveis de estoques na produção. Deste modo, são utilizadas ferramentas como kanbans, painéis de gestão à vista, dispositivos "pokayoke", etc. Para efetivar seu compromisso com a qualidade, a "empresa A" pretende implantar um sistema de gestão da qualidade aos moldes dos requisitos ISO 9001:2000 para, posteriormente, buscar a certificação nestes requisitos.

Também localizada em Araraquara, a "empresa B" iniciou suas atividades na região a partir de 2003 e hoje possui cerca de vinte e cinco funcionários no seu quadro de efetivos. Além do serviço de locação de veículos, a empresa conta com o serviço denominado "serviços de táxi", o qual é realizado mediante formalização de contrato com o cliente. Embora seja considerada uma empresa de pequeno porte, a "empresa B" pretende ampliar a oferta de serviços ao mercado buscando novos clientes e o crescimento organizacional.

Dentre as práticas de gestão da qualidade da "empresa B" destacam-se os serviços de atendimento ao cliente, o desenvolvimento das competências necessárias aos principais cargos (motoristas e mecânicos) e o monitoramento dos processos e serviços, que incluem o uso de listas de verificação para monitorar o atendimento aos requisitos necessários para a satisfação do cliente. Para o próximo ano, a organização pretende dobrar a sua frota de veículos e adequar suas práticas aos requisitos ISO 9001:2000. visando o aumento da satisfação dos clientes. 
A filial "empresa C" está localizada na região de Araraquara, onde iniciou suas atividades a partir de 2001. Hoje a organização conta com cerca de cento e vinte colaboradores altamente capacitados na prestação de serviços em limpeza profissional. A matriz da "empresa C" está localizada em Taubaté - SP e além da prestação de serviços de limpeza convencional, técnica, jardinagem e outras atividades do ramo, possui uma diversificada linha de produtos para limpeza tais como desinfetantes, saboneteiras, rolos de papel-toalha, lixeiras, etc. Para alcançar a eficiência e minimizar os custos operacionais, a "empresa C" conta com equipamentos de alta tecnologia, incluindo varredeiras com piloto a bordo, lavadoras extratoras de carpete, etc.

Fazem parte da filosofia da qualidade da "empresa C" o atendimento personalizado e o uso de tecnologia aplicada. Além disso, a organização vem adotando uma política de aperfeiçoamento contínuo de seus colaboradores através de treinamentos como programa $5 \mathrm{~S}$, qualidade no atendimento, meio ambiente $\mathrm{e}$ atendimento aos requisitos do cliente. Para os próximos meses, a organização pretende direcionar seus esforços na busca do certificado ISO 9001:2000.

Localizada em São Jose dos Campos - SP, a "empresa D” pertence a um grupo multinacional que atua em setenta e seis países e conta com mais de trezentos mil profissionais, distribuídos em vinte e três mil e novecentas unidades operacionais. A América Latina representa três por cento do faturamento e conta com mais de vinte e oito mil colaboradores distribuidos em mil e trezentas unidades instaladas em sete países. Além dos serviços de alimentação, o grupo oferece aos seus clientes mais de trinta e dois tipos de serviços, incluindo lavanderia, recepção, limpeza, telefonia, etc. $\mathrm{O}$ grupo também atua em diversos segmentos, tais como empresas, hospitais, escolas, etc.

Atualmente, a "empresa D" possui cerca de trezentos funcionários e suas atividades foram iniciadas por volta de 1990. A “empresa D” não possui uma política da qualidade específica. Contudo, os valores adotados pelo grupo são traduzidos e comunicados à empresa. Fazem parte destes valores, o foco no cliente, o espírito de equipe, a melhoria contínua e a tomada de iniciativa. O compromisso com a qualidade na "empresa D" abrange a segurança alimentar e conta com o apoio da área de qualidade, responsável por gerenciar os processos e métodos empregados na manipulação dos alimentos, de acordo com a legislação aplicável. A gestão da qualidade faz parte da rotina da organização há alguns anos através da adequação dos processos e do sistema documental aos requisitos ISO 9000. Embora a organização não seja 
certificada, existe uma preocupação em relação ao atendimento dos requisitos pertinentes ao sistema de gestão da qualidade e do sistema de segurança alimentar.

Constituída de capital $100 \%$ nacional, a "empresa E" atua no setor sucroalcooleiro há mais de cinqüenta anos e seu quadro de funcionários conta com mais de três mil funcionários capacitados. Localizada na região central do Estado de São Paulo, próxima à região de Ribeirão Preto, a empresa está entre as quinze maiores unidades do país, considerando sua capacidade instalada capaz de processar diariamente cerca de dezoito mil de toneladas de cana-de-açúcar, o que permite a produção diária de vinte e cinco mil sacas de açúcar e um milhão de litros de álcool.

No início da década de 1990, a alta direção da organização passou a disseminar uma cultura voltada à satisfação de seus clientes através da qualidade dos produtos produzidos. Em 1993, a organização implantou um programa de qualidade total que resultou na conquista do certificado ISO 9002 no ano de 1997 e, posteriormente, o certificado ISO 9001:2000 no ano de 2002. Desde então, a empresa vem buscando a manutenção e melhoria de seu sistema de gestão da qualidade.

\subsection{Resultados da avaliação}

Este tópico descreve a aplicação da proposta nas empresas selecionadas e os resultados desta aplicação. Estes resultados foram extraídos dos relatórios de gestão das empresas avaliadas e incluem a sintese da pontuação obtida para cada empresa, bem como um resumo sobre os principais pontos fortes e oportunidades para melhoria, levando em consideração os princípios de gestão abordados na norma NBR ISO 9001:2000.

\subsubsection{Empresa A}

A avaliação na "empresa A" foi realizada no mês de novembro de 2004 e durou aproximadamente sete horas. Participaram das entrevistas, os diretores comercial e industrial, o gerente de produção e funcionários da produção. Antes e durante as entrevistas, o pesquisador analisou vários documentos incluindo desenhos técnicos, ordens de fabricação, mapas, registros e etc. Embora a emprèsa não tenha o certificado 
ISO 9001:2000, muitas atividades de realização do produto estão padronizadas e monitoradas conforme requisitos internos. Entretanto, os requisitos sistêmicos, tais como os requisitos de documentação, ação corretiva e preventiva. auditorias internas, treinamento e outros, não estão devidamente implementados. O Quadro 26 apresenta a síntese da pontuação obtida pela "empresa A".

Quadro 26 - Síntese da pontuação obtida pela "empresa A"

\begin{tabular}{|c|c|c|c|}
\hline Itens de Avaliação & $\begin{array}{l}\text { Pontuação } \\
\text { Máxima }\end{array}$ & $\begin{array}{l}\text { Percentual } \\
\text { Obtido }\end{array}$ & $\begin{array}{l}\text { Pontuação } \\
\text { Obtida }\end{array}$ \\
\hline $\begin{array}{l}\text { 1. Sistema de Gestão da Qualidade } \\
\text { 1.1. Requisitos gerais }\end{array}$ & 150 & $40 \%$ & 60 \\
\hline 1.2. Requisitos de documentação & 150 & $10 \%$ & 15 \\
\hline \multicolumn{4}{|l|}{ 2. Responsabilidade da Direção } \\
\hline $\begin{array}{l}\text { 2.1. Comprometimento da direção, foco no cliente, } \\
\text { politica da qualidade e planejamento }\end{array}$ & 100 & $20 \%$ & 20 \\
\hline $\begin{array}{l}\text { 2.2. Responsabilidade e autoridade, representante da } \\
\text { direção, comunicação interna e análise critica } \\
\text { pela direção }\end{array}$ & 100 & $20 \%$ & 20 \\
\hline \multicolumn{4}{|l|}{ 3. Gestão de Recursos } \\
\hline $\begin{array}{l}\text { 3.1. Provisão de recursos, infra-estrutura e ambiente } \\
\text { de trabalho }\end{array}$ & 70 & $90 \%$ & 63 \\
\hline 3.2. Recursos humanos & 70 & $20 \%$ & 14 \\
\hline \multicolumn{4}{|l|}{ 4. Realização do Produto } \\
\hline $\begin{array}{l}\text { 4.1. Planejamento da realização do produto, e } \\
\text { processos relacionados a clientẹs }\end{array}$ & 40 & $80 \%$ & 32 \\
\hline 4.2. Projeto e desenvolvimento & 40 & $90 \%$ & 36 \\
\hline $\begin{array}{l}\text { 4.3. Aquisição e controle de dispusitivos de medição } \\
\text { e monitoramento }\end{array}$ & 40 & $40 \%$ & 16 \\
\hline 4.4. Produção e fornecimento de serviço & 40 & $50 \%$ & 20 \\
\hline \multicolumn{4}{|l|}{ 5. Medição, Análise e Melhoria } \\
\hline 5.1. Medição e monitoramento & 100 & $30 \%$ & 30 \\
\hline $\begin{array}{l}\text { 5.2. Controle de produto não-conforme, análise de } \\
\text { dados e melhorias }\end{array}$ & 100 & $10 \%$ & 10 \\
\hline Total Geral & 1000 & & 336 \\
\hline
\end{tabular}




\section{Foco no cliente}

Pontos fortes: Antes de assumir o compromisso de fornecimento, a organização analisa criticamente os requisitos do cliente (definidos no pedido) com base nos estoques de segurança e na capacidade em atender esses requisitos. Os registros desta análise são mantidos juntamente com os pedidos. Além disso, a organização dispõe de canais de comunicação adequados (telefones, televendas, websites, etc.) para dar informações sobre o produto, ao tratamento de consultas, contratos ou pedidos, reclamações, etc. As reclamações de clientes são registradas para posterior análise e atendimento.

Oportunidades para melhoria: Embora a organização obtenha informações relativas à percepção do cliente quanto o atendimento aos seus requisitos (apenas quando o cliente entra em contato com a organização), não há evidência de que os métodos para obtenção e uso destas informações estejam determinados.

\section{Liderança}

Pontos fortes: Os processos de comunicação da empresa incluem o uso de quadro de avisos, e-mail, telefone, etc. Tais processos permitem a disseminação das diretrizes estabelecidas pela alta direção.

Oportunidades para melhoria: Não foi possível evidenciar o comprometimento da organização com o sistema de gestão da qualidade mediante a designação formal do representante da direção, o estabelecimento da política da qualidade, dos objetivos da qualidade e da condução de análises críticas pela alta direção.

\section{Envolvimento das pessoas}

Pontos fortes: A organização incentiva o crescimento profissional e a capacitação dos colaboradores. Para isso, a empresa identifica e divulga um calendário de cursos profissionalizantes realizados por instituições da região. Esses cursos estão relacionados às competências necessárias para cargos, que são estabelecidas informalmente pela alta direção.

Oportunidades para melhoria: Não foi possível evidenciar que o pessoal que executa atividades que afetam a qualidade do produto esteja consciente quanto à pertinência e 
importância dessas atividades e de como elas contribuem para atingir os objetivos da qualidade, visto que os objetivos da qualidade não foram estabelecidos e comunicados. Além disso, não há evidências de que a organização forneça treinamento ou realize outras ações para satisfazer as necessidades de competência e avalie a eficácia das ações executadas, bem como mantém os registros apropriados de educação, treinamento, habilidade e experiência.

\section{Abordagem de processo}

Pontos fortes: Os critérios e métodos necessários para assegurar que a operação e o controle dos processos que afetam o sistema de gestão da qualidade sejam eficazes estão definidos através de desenhos técnicos, ordens de fabricação e outras especificações estabelecidas pelo gerente de produção.

Oportunidades para melhorias: Não há evidências de que a organização identifica a situação do produto ao longo dos processos de realização, de modo a assegurar sua rastreabilidade. Além disso, não há evidências de que quando os resultados planejados não são alcançados, a organização executa ações para assegurar a conformidade do produto. A seqüência e interação dos processos relacionados ao sistema de gestão da qualidade não estão claramente identificados e determinados pela organização.

\section{Abordagem sistêmica para a gestão}

Pontos fortes: A organização planeja e controla o projeto e desenvolvimento do produto estabelecendo seus estágios, incluindo análise crítica, verificação e validação, bem como as responsabilidades e autoridades. A gerência de produção mantém os registros das entradas e saídas de projeto e desenvolvimento em meio eletrônico (arquivo project).

Oportunidades para melhoria: A documentação do sistema de gestão da qualidade não inclui declarações da política da qualidade e dos objetivos da qualidade, manual da qualidade e procedimentos e registros requeridos pela norma NBR ISO 9001:2000. Além disso, a organização não realiza auditorias internas a intervalos planejados, para verificar a efetividade do sistema de gestão da qualidade segundo os requisitos normativos ISO 9001:2000. 


\section{Melhoria contínua}

Oportunidades para melhoria: Não foi possível evidenciar a melhoria contínua do sistema de gestão da qualidade da organização mediante o estabelecimento da política da qualidade, dos objetivos da qualidade, da implementação de ações corretivas e preventivas, bem como da condução de análises críticas pela alta direção.

\section{Abordagem factual para a tomada de decisão}

Pontos fortes: Todas as alterações de projeto e desenvolvimento são analisadas, validadas e aprovadas pela gerência de produção, que mantém os registros desta natureza em meio eletrônico.

Oportunidades para melhoria: Não há evidências de que a organização possui um procedimento documentado para controlar os registros aplicáveis, incluindo os registros de ações preventivas e corretivas, formulários de monitoramento de processos e produtos, registros de reclamações de clientes, atas de análises críticas, relatórios de auditorias, etc.

\section{Benefícios mútuos nas relações com os fornecedores}

Oportunidades para melhoria: Não há evidências de que a organização estabeleceu critérios para seleção, avaliação e reavaliação de seus fornecedores para selecioná-los com base na sua capacidade em fornecer produtos de acordo com os requisitos especificados, assim como não há registros de avaliações desta natureza e ações pertinentes. 


\subsubsection{Empresa B}

A avaliação da "empresa B" foi realizada no mês de dezembro de 2004 e durou aproximadamente seis horas. Devido ao porte da empresa, a entrevista foi realizada apenas com o gerente geral, responsável pelas atividades relacionadas a qualidade. Foram analisados vários documentos incluindo especificações dos clientes, ordens de serviços, registros, etc.

Com base na pontuação obtida pela "empresa B", conforme apresentado no Quadro 27, é possível verificar um baixo percentual principalmente em relação aos requisitos de documentação, o que pode ser compreendido face o porte da organização. Além disso, os requisitos de projeto e desenvolvimento, controle de produto nãoconforme, análise de dados e melhorias, assim como os requisitos relacionados à responsabilidade da direção, também receberam um baixo percentual, entre 20 e $30 \%$. Em contrapartida, os requisitos relativos à provisão de recursos, infra-estrutura e ambiente de trabalho, e também os requisitos de planejamento da realização do produto e processos relacionados a clientes obtiveram $100 \%$ da pontuação.

\section{$>$ Foco no cliente}

Pontos fortes: A organização assegura que os requisitos do cliente são determinados e atendidos mediante a elaboração de contratos mensais e diários. O serviço de telemarketing assegura a comunicação eficaz com o cliente quanto ao tratamento de consultas, contratos, pedidos e reclamações.

Oportunidades para melhoria: Não há uma sistemática devidamente formalizada para o registro e análise das reclamações do cliente. Além disso, não foi possível evidenciar o formulário de pesquisa de satisfação de clientes, visto que o mesmo está em fase de implantação. 
Quadro 27 - Síntese da pontuação obtida pela "empresa B"

\begin{tabular}{|c|c|c|c|}
\hline Itens de Avaliação & $\begin{array}{l}\text { Pontuação } \\
\text { Máxima }\end{array}$ & $\begin{array}{l}\text { Percentual } \\
\text { Obtido }\end{array}$ & $\begin{array}{l}\text { Pontuação } \\
\text { Obtida }\end{array}$ \\
\hline $\begin{array}{l}\text { 1. Sistema de Gestão da Qualidade } \\
\text { 1.1. Requisitos gerais }\end{array}$ & 150 & $50 \%$ & 75 \\
\hline 1.2. Requisitos de documentação & 150 & $10 \%$ & 15 \\
\hline \multicolumn{4}{|l|}{ 2. Responsabilidade da Direção } \\
\hline $\begin{array}{l}\text { 2.1. Comprometimento da direção, foco no cliente, } \\
\text { política da qualidade e planejamento }\end{array}$ & 100 & $30 \%$ & 30 \\
\hline $\begin{array}{l}\text { 2.2. Responsabilidade e autoridade, representante da } \\
\text { direção, comunicação interna e análise crítica } \\
\text { pela direção }\end{array}$ & 100 & $30 \%$ & 30 \\
\hline \multicolumn{4}{|l|}{ 3. Gestão de Recursos } \\
\hline $\begin{array}{l}\text { 3.1. Provisão de recursos, infra-estrutura e ambiente } \\
\text { de trabalho }\end{array}$ & 70 & $100 \%$ & 70 \\
\hline 3.2. Recursos humanos & 70 & $50 \%$ & 35 \\
\hline \multicolumn{4}{|l|}{ 4. Realização do Produto } \\
\hline $\begin{array}{l}\text { 4.1. Planejamento da realização do produto, e } \\
\text { processos relacionados a clientes }\end{array}$ & 40 & $100 \%$ & 40 \\
\hline 4.2. Projeto e desenvolvimento & 40 & $10 \%$ & 04 \\
\hline $\begin{array}{l}\text { 4.3. Aquisição e controle de dispositivos de medição } \\
\text { e monitoramento }\end{array}$ & 40 & $70 \%$ & 28 \\
\hline 4.4. Produção e fornecimento de serviço & 40 & $90 \%$ & 36 \\
\hline \multicolumn{4}{|l|}{ 5. Medição, Análise e Melhoria } \\
\hline 5.1. Medição e monitoramento & 100 & $50 \%$ & 50 \\
\hline $\begin{array}{l}\text { 5.2. Controle de produto não-conforme, análise de } \\
\text { dados e melhorias }\end{array}$ & 100 & $20 \%$ & 20 \\
\hline Total Geral & 1000 & & 433 \\
\hline
\end{tabular}

\section{Liderança}

Pontos fortes: Os processos de comunicação permitem a disseminação das diretrizes estabelecidas pela alta direção. A divulgação através de quadro de avisos, e-mail, telefonia móvel, bem como a condução de reuniões informais, possibilitam a comunicação sobre as responsabilidades e autoridades definidas pela organização. 
Oportunidades para melhoria: Não foi possível evidenciar o comprometimento da organização com o sistema de gestão da qualidade mediante a designação formal do representante da direção, o estabelecimento da política da qualidade, dos objetivos da qualidade, da condução de análises críticas pela alta direção.

\section{Envolvimento das pessoas}

Pontos fortes: Além dos processos de comunicação estabelecidos, foi observado que o porte da organização facilita a comunicação quanto às responsabilidades e autoridades pertinentes às pessoas que executam trabalhos que afetam a qualidade do fornecimento do serviço.

Oportunidades para melhoria: As competências necessárias ao pessoal que executa atividades que afetam a qualidade do serviço prestado (descrição de cargo) não estão documentadas de modo a prover evidências de sua efetividade. Além disso, não foram evidenciados registros de treinamento incluindo o levantamento das necessidades e as avaliações da eficácia.

\section{Abordagem de processo}

Pontos fortes: A organização disponibiliza os recursos e informações necessários para apoiar a operação e o monitoramento dos processos que afetam o sistema de gestão da qualidade, incluindo os processos administrativo, comercial e operacional. Além disso, a organização realiza inspeção com o objetivo de comprovar a capacidade dos processos em alcançar os resultados planejados.

Oportunidades para melhoria: A seqüência e a interação dos processos relacionados ao sistema de gestão da qualidade, incluindo os processos de fornecimento de serviço e de apoio, bem como suas entradas e saídas, não estão claramente identificados e determinados pela organização. 


\section{Abordagem sistêmica para a gestão}

Pontos fortes: Os recursos necessários para a implantação do sistema de gestão da qualidade, tais como instalações, pessoas, equipamentos, etc., são determinados e fornecidos pela organização. O sistema informatizado "Henje" permite o controle do fornecimento de serviço prestado.

Oportunidades para melhoria: A documentação do sistema de gestão da qualidade não inclui declarações da política da qualidade e dos objetivos da qualidade, manual da qualidade e procedimentos e registros requeridos pela norma NBR ISO 9001:2000. Além disso, não há uma sistemática para a realização de auditorias internas a intervalos planejados, para verificar a efetividade do sistema de gestão da qualidade segundo os requisitos normativos ISO 9001:2000.

\section{Melhoria contínua}

Pontos fortes: A organização busca melhorar continuamente o sistema de gestão da qualidade com base nas entrevistas realizadas com os clientes, visando aumentar a sua satisfação.

Oportunidades para melhoria: Não foi possível evidenciar a melhoria contínua do sistema de gestão da qualidade da organização mediante o estabelecimento da política da qualidade, dos objetivos da qualidade, da implementação de ações corretivas e preventivas, bem como da condução de análises críticas pela alta direção.

\section{Abordagem factual para a tomada de decisão}

Pontos fortes: A organização determina e analisa dados obtidos das medições do fornecimento do serviço, bem como da realimentação de clientes visando avaliar oportunidades para a melhoria contínua do sistema de gestão da qualidade.

Oportunidades para melhoria: Não há evidências de que a organização possui um procedimento documentado para controlar os registros aplicáveis. 
$>$ Benefícios mútuos nas relações com os fornecedores

Oportunidades para melhoria: O processo de aquisição da organização inclui a seleção de pelo menos três fornecedores para cada tipo de produto ou serviço a ser adquirido. Entretanto, não há evidências de que são mantidos os registros de seleção, avaliação e reavaliação desses fornecedores.

\subsubsection{Empresa C}

A "empresa C" foi avaliada no dia 07 de dezembro de 2004 e durou aproximadamente oito horas. Foram entrevistados o supervisor geral, o assessor da qualidade e a assistente administrativa. A análise documental incluiu mapas de processos, instruções de trabalho, contratos, registros, etc.

A pontuação obtida pela "empresa $C$ " revela que os requisitos de controle de produto não-conforme, análise de dados e melhorias estão dentro de uma faixa de pontuação relativamente baixa, representando $20 \%$ da pontuação pertinente. Os requisitos: comprometimento da direção, foco no cliente, política da qualidade e planejamento, assim como os requisitos de documentação, também receberam um percentual relativamente baixo, representando $30 \%$ da pontuação máxima. O requisito projeto e desenvolvimento obteve a pontuação mínima de $0 \%$, levando em consideração o fato de que a empresa, embora não tenha desenvolvido outros tipos de serviço além daqueles contemplados no contrato com o cliente, não estabeleceu uma rotina para o atendimento ao requisito de projeto e desenvolvimento da norma NBR ISO 9001:2000.

Os requisitos provisão de recursos, infra-estrutura e ambiente de trabalho, assim como planejamento da realização do produto e processos relacionados a clientes, receberam a melhor pontuação 90 e $80 \%$ respectivamente. O Quadro 28 apresenta a síntese da pontuação obtida pela "empresa C". 
Quadro 28 - Síntese da pontuação obtida pela "empresa C"

\begin{tabular}{|c|c|c|c|}
\hline Itens de Avaliação & $\begin{array}{l}\text { Pontuação } \\
\text { Máxima }\end{array}$ & $\begin{array}{l}\text { Percentual } \\
\text { Obtido }\end{array}$ & $\begin{array}{l}\text { Pontuação } \\
\text { Obtida }\end{array}$ \\
\hline 1. Sistema de Gestão da Qualidade & 150 & $70 \%$ & 105 \\
\hline 1.2. Requisitos de documentação & 150 & $30 \%$ & 45 \\
\hline \multicolumn{4}{|l|}{ 2. Responsabilidade da Direção } \\
\hline $\begin{array}{l}\text { 2.1. Comprometimento da direção, foco no cliente, } \\
\text { política da qualidade e planejamento }\end{array}$ & 100 & $30 \%$ & 30 \\
\hline $\begin{array}{l}\text { 2.2. Responsabilidade e autoridade, representante da } \\
\text { direção, comunicação interna e análise crítica } \\
\text { pela direção }\end{array}$ & 100 & $40 \%$ & 40 \\
\hline \multicolumn{4}{|l|}{ 3. Gestão de Recursos } \\
\hline $\begin{array}{l}\text { 3.1. Provisão de recursos, infra-estrutura e ambiente } \\
\text { de trabalho }\end{array}$ & 70 & $90 \%$ & 63 \\
\hline 3.2. Recursos humanos & 70 & $50 \%$ & 35 \\
\hline \multicolumn{4}{|l|}{ 4. Realização do Produto } \\
\hline $\begin{array}{l}\text { 4.1. Planejamento da realização do produto, e } \\
\text { processos relacionados a clientes }\end{array}$ & 40 & $80 \%$ & 32 \\
\hline 4.2. Projeto e desenvolvimento & 40 & $0 \%$ & 0 \\
\hline $\begin{array}{l}\text { 4.3. Aquisição e controle de dispositivos de medição } \\
\text { e monitoramento }\end{array}$ & 40 & $50 \%$ & 20 \\
\hline 4.4. Produção e fornecimento de serviço & 40 & $40 \%$ & 16 \\
\hline \multicolumn{4}{|l|}{ 5. Medição, Análise e Melhoria } \\
\hline 5.1. Medição e monitoramento & 100 & $60 \%$ & 60 \\
\hline $\begin{array}{l}\text { 5.2. Controle de produto não-conforme, análise de } \\
\text { dados e melhorias }\end{array}$ & 100 & $20 \%$ & 20 \\
\hline Total Geral & 1000 & & 466 \\
\hline
\end{tabular}

\section{Foco no cliente}

Pontos fortes: Com base na especificação técnica estabelecida no documento "ESPEC" é possível identificar os requisitos do cliente e desdobrá-los aos processos de fornecimento de serviço visando o atendimento a estes requisitos. Através dos recursos de telefonia fixa e móvel, são esclarecidas eventuais dúvidas quanto ao fornecimento de serviço entre o cliente e a organização. A pesquisa mensal "Avaliação dos Serviços 
Prestados", bem como a "Central de Atendimento" permitem a verificação do atendimento aos requisitos estabelecidos pelo cliente.

Oportunidades para melhoria: Não há uma sistemática devidamente formalizada para o registro e análise das reclamações do cliente.

\section{Liderança}

Pontos fortes: Os processos de comunicação estabelecidos pela organização permitem a disseminação do comprometimento da alta direção. A divulgação através de quadro de avisos, bem como a condução de reuniões mensais registradas em ata, possibilita a comunicação sobre as responsabilidades e autoridades definidas pela organização.

Oportunidades para melhoria: Não foi possível evidenciar o comprometimento da organização com o sistema de gestão da qualidade mediante a designação formal do representante da direção, o estabelecimento da política da qualidade, dos objetivos da qualidade, da condução de análises críticas pela alta direção.

\section{Envolvimento das pessoas}

Pontos fortes: Além dos processos de comunicação estabelecidos, foi observado que o porte da organização facilita a comunicação quanto às responsabilidades e autoridades pertinentes às pessoas que executam trabalhos que afetam a qualidade do fornecimento do serviço.

Oportunidades para melhoria: As competências necessárias ao pessoal que executa atividades que afetam a qualidade do serviço prestado não estão documentadas de modo a prover evidências de sua efetividade. Além disso, não foram evidenciados registros do levantamento das necessidades de treinamento, das avaliações da eficácia, bem como de treinamentos nas instruções de trabalho vigentes. 
$>$ Abordagem de processo

Pontos fortes: A organização realiza o planejamento e o desenvolvimento dos processos necessários ao sistema de gestão da qualidade levando em consideração as especificações do cliente. Tais especificações são desdobradas para as atividades operacionais. Desta forma, o monitoramento dos processos é realizado através do "Quadro de Efetivos", das reuniões mensais e das inspeções in loco conduzidas pelos líderes.

Oportunidades para melhoria: A seqüência e a interação destes processos, incluindo os processos de fornecimento de serviço e de apoio, bem como suas entradas e saídas, não estão claramente identificadas e determinadas pela organização.

\section{Abordagem sistêmica para a gestão}

Pontos fortes: Os recursos necessários para a implantação do sistema de gestão da qualidade, tais como instalações, pessoas, equipamentos, sofiwares, documentos etc., são determinados e fornecidos pela organização. Os documentos do tipo instrução de trabalho, formulários e registros estão sistematizados e disponíveis aos locais de uso.

Oportunidades para melhoria: A documentação do sistema de gestão da qualidade não inclui declarações da política da qualidade e dos objetivos da qualidade, manual da qualidade e procedimentos e registros requeridos pela norma NBR ISO 9001:2000. Além disso, não há uma sistemática para a realização de auditorias internas a intervalos planejados, para verificar a efetividade do sistema de gestão da qualidade segundo os requisitos normativos ISO 9001:2000.

\section{- Melhoria contínua}

Pontos fortes: Com base nos resultados da pesquisa de satisfação do cliente, é possível observar a evolução do atendimento aos requisitos do cliente.

Oportunidades para melhoria: Não foi possível evidenciar a melhoria contínua do sistema de gestão da qualidade da organização mediante o estabelecimento da política da qualidade, dos objetivos da qualidade, da implementação de ações corretivas e preventivas, bem como da condução de análises críticas pela alta direção. 


\section{Abordagem factual para a tomada de decisão}

Pontos fortes: A organização determina e analisa dados obtidos das medições do produto e do fornecimento do serviço, bem como da realimentação de clientes visando avaliar oportunidades para a melhoria contínua do sistema de gestão da qualidade.

Oportunidades para melhoria: Não há evidências de que a organização possui um procedimento documentado para controlar os registros aplicáveis.

\section{Benefícios mútuos nas relações com os fornecedores}

Oportunidades para melhoria: A relação com os fornecedores de produtos e serviços que afetam a qualidade do fornecimento de serviço não é diretamente realizada pela organização, ou seja, os produtos e serviços são adquiridos através da matriz, que possui responsabilidade para selecionar, avaliar e reavaliar seus fornecedores. Neste sentido, não foi possível evidenciar a aderência dos processos de aquisição aos requisitos normativos pertinentes.

\subsubsection{Empresa D}

A avaliação da "empresa D" foi realizada dia 13 de dezembro de 2004 e teve a duração de aproximadamente oito horas. Participaram das entrevistas o supervisor geral, o administrador da unidade, a coordenadora de recursos humanos e também a assistente da qualidade. Boa parte da documentação adotada pela "empresa D" é fornecida pela matriz com o intuito de disseminar a preocupação com a qualidade de seus produtos a todas as unidades instaladas no país. Deste modo, foi possível analisar uma estrutura documental mais aderente aos requisitos ISO 9001:2000, incluindo procedimentos gerenciais, manuais de gestão, instruções de trabalho, dados do sistema, registros, etc.

A sintese de pontuação apresentada no Quadro 29 demonstra que o item referente ao projeto e desenvolvimento obteve o menor percentual, ou seja, $10 \%$ do percentual máximo. Essa pontuação foi aplicada levando em consideração um tipo de serviço diferenciado, que foi oferecido ao cliente. Embora a "empresa D" atenda parte dos requisitos de projeto e desenvolvimento, as atividades pertinentes não se encontram sistematizadas e também não foi possível evidenciar registros desta natureza. 
Quadro 29 - Síntese da pontuação obtida pela "empresa D"

\begin{tabular}{|c|c|c|c|}
\hline Itens de Avaliação & $\begin{array}{l}\text { Pontuação } \\
\text { Máxima }\end{array}$ & $\begin{array}{l}\text { Percentual } \\
\text { Obtido }\end{array}$ & $\begin{array}{l}\text { Pontuação } \\
\text { Obtida }\end{array}$ \\
\hline $\begin{array}{l}\text { 1. Sistema de Gestão da Qualidade } \\
\text { 1.1. Requisitos gerais }\end{array}$ & 150 & $70 \%$ & 105 \\
\hline 1.2. Requisitos de documentação & 150 & $30 \%$ & 45 \\
\hline \multicolumn{4}{|l|}{ 2. Responsabilidade da Direção } \\
\hline $\begin{array}{l}\text { 2.1. Comprometimento da direção, foco no cliente, } \\
\text { política da qualidade e planejamento }\end{array}$ & 100 & $30 \%$ & 30 \\
\hline $\begin{array}{l}\text { 2.2. Responsabilidade e autoridade, representante da } \\
\text { direção, comunicação interna e análise crítica } \\
\text { pela direção }\end{array}$ & 100 & $40 \%$ & 40 \\
\hline \multicolumn{4}{|l|}{ 3. Gestão de Recursos } \\
\hline $\begin{array}{l}\text { 3.1. Provisào de recursos, infra-estrutura e ambiente } \\
\text { de trabalho }\end{array}$ & 70 & $90 \%$ & 63 \\
\hline 3.2. Recursos humanos & 70 & $60 \%$ & 42 \\
\hline \multicolumn{4}{|l|}{ 4. Realização do Produto } \\
\hline $\begin{array}{l}\text { 4.1. Planejamento da realização do produto, e } \\
\text { processos relacionados a clientes }\end{array}$ & 40 & $80 \%$ & 32 \\
\hline 4.2. Projeto e desenvolvimento & 40 & $10 \%$ & 04 \\
\hline $\begin{array}{l}\text { 4.3. Aquisição e controle de dispositivos de medição } \\
\text { e monitoramento }\end{array}$ & 40 & $90 \%$ & 36 \\
\hline 4.4. Produçào e fornecimento de serviço & 40 & $90 \%$ & 36 \\
\hline \multicolumn{4}{|l|}{ 5. Medição, Análise e Melhoria } \\
\hline 5.1. Medição e monitoramento . & 100 & $70 \%$ & 70 \\
\hline $\begin{array}{l}\text { 5.2. Controle de produto não-conforme, análise de } \\
\text { dados e melhorias }\end{array}$ & 100 & $30 \%$ & 30 \\
\hline Total Geral & 1000 & & 533 \\
\hline
\end{tabular}

\section{Foco no cliente}

Pontos fortes: A organização assegura que os requisitos do cliente são determinados através da análise crítica de contrato e reuniões semanais (reuniões de cardápio). Além disso, a organização utiliza métodos eficazes para obtenção e uso das informações relativas à percepção do cliente quanto ao atendimento aos seus requisitos. Tais 
métodos incluem: pesquisa de satisfação diária, pesquisa "conte comigo" e pesquisa anual.

Oportunidades para melhoria: Embora constatado que o cliente participe da validação do projeto, como por exemplo, a inclusão do serviço "pasta a jato", não foi possível evidenciar que a organização mantém os registros dos resultados de validação do projeto e ações pertinentes.

\section{Liderança}

Pontos fortes: Os processos de comunicação estabelecidos pela organização, incluindo o uso de quadro de avisos e a realização de reuniões de turno, permitem a disseminação do comprometimento da alta direção. Além disso, o porte da empresa permite a comunicação informal entre os colaboradores e a alta direção.

Oportunidades para melhoria: Não foi possivel evidenciar o comprometimento da organização com o sistema de gestão da qualidade mediante a designação formal do representante da direção, o estabelecimento da política da qualidade e dos objetivos da qualidade e a condução de análises críticas pela alta direção.

\section{Envolvimento das pessoas}

Pontos fortes: Os processos de comunicação estabelecidos pela organização, tais como comunicados em quadro de avisos e reuniões diárias (quinze minutos por turno) permitem a comunicação eficaz quanto às responsabilidades e autoridades pertinentes às pessoas que executam trabalhos que afetam a qualidade do fornecimento do serviço.

Oportunidades para melhoria: As competências necessárias ao pessoal que executa atividades que afetam a qualidade do serviço prestado não estão documentadas de modo a prover evidências de sua efetividade. Além disso, não foram evidenciados registros do levantamento das necessidades de treinamento, bem como das avaliações da eficácia de treinamento. 


\section{Abordagem de processo}

Pontos fortes: O documento "Manual de Procedimentos Técnicos" evidencia o planejamento e o desenvolvimento dos processos necessários ao sistema de gestão da qualidade. Além disso, a organização estabelece os critérios e métodos necessários para assegurar a operação e o controle desses processos, incluindo inspeções e auditorias internas.

Oportunidades para melhoria: A sequiência e a interação dos processos de apoio (recursos humanos, gestão da qualidade, gestão financeira, tecnologia de informação, etc.), bem como suas entradas e saídas, não estão claramente identificadas e determinadas pela organização.

\section{Abordagem sistêmica para a gestão}

Pontos fortes: Os recursos necessários para a implantação do sistema de gestão da qualidade, tais como instalações, pessoas, equipamentos, softwares, documentos etc., são determinados e fornecidos pela organização. A documentação pertinente ao sistema de gestão da qualidade incluindo manuais de procedimentos técnicos, formulários e registros estão sistematizados e disponíveis nos locais de uso.

Oportunidades para melhoria: A documentação do sistema de gestão da qualidade não inclui declarações da política da qualidade e dos objetivos da qualidade, manual da qualidade e procedimentos e registros requeridos pela norma NBR ISO 9001:2000. Além disso, o planejamento das auditorias internas não inclui a verificação da efetividade do sistema de gestão da qualidade segundo os requisitos normativos ISO 9001:2000.

\section{Melhoria contínua}

Pontos fortes: Os dados obtidos através das medições do fornecimento do serviço e da realimentação de clientes, tais como pesquisa de satisfação de cliente, registros de monitoramento dos processos, resultados de auditoria, etc., permitem que a organização avalie oportunidades para a melhoria contínua do sistema de gestão da qualidade. 
Oportunidades para melhoria: Não foi possível evidenciar a melhoria contínua do sistema de gestão da qualidade da organização mediante o estabelecimento da política da qualidade, dos objetivos da qualidade, da implementação de ações corretivas e preventivas, bem como da condução de análises críticas pela alta direção.

\section{Abordagem factual para a tomada de decisão}

Pontos fortes: A organização determina e analisa dados obtidos das medições do fornecimento do serviço, bem como da realimentação de clientes visando avaliar oportunidades para a melhoria contínua do sistema de gestão da qualidade.

Oportunidades para melhoria: Não há evidências de que a organização possui um procedimento documentado segundo os requisito 4.2 .4 (controle de registro) da norma NBR ISO 9001:2000 para controlar os registros aplicáveis.

\section{Beneficios mútuos nas relaçöes com os fornecedores}

Pontos fortes: Os critérios para seleção, avaliação e reavaliação para avaliar e selecionar os fornecedores com base na sua capacidade em fornecer produtos de acordo com os requisitos especificados pela organização estão estabelecidos no documento "Manual de Procedimentos Técnicos".

Oportunidades para melhoria: As informações de aquisição registradas no sistema "TEC FOOD" descrevem o produto a ser adquirido. Porém, não contemplam aspectos como a qualificação do pessoal envolvido e sistema de gestão da qualidade. Além disso, os registros de seleção, avaliação e reavaliação dos fornecedores são mantidos pelo escritório central, o que dificulta o acesso a esses documentos. 


\subsubsection{Empresa E}

A avaliação da "empresa E" foi realizada nos dias 13 e 14 de janeiro de 2005 e teve a duração de aproximadamente onze horas. Participaram das entrevistas o gerente industrial. o coordenador da produção, o coordenador de gestão da qualidade, a analista de gestão da qualidade. operadores da área industrial, e assistentes da área administrativa. A "empresa E" possui um sistema de gestão da qualidade "maduro", visto que a primeira certificação ocorreu em 1997. Desde então, as rotinas passaram a ser estabelecidas nos procedimentos e instruções de trabalho assegurando a efetividade das tarefas que afetam a qualidade do produto. Além de toda a documentação pertinente ao sistema, os registros revelam o compromisso efetivo com o sistema de gestão da qualidade.

A síntese de pontuação apresentada no Quadro 30 demonstra o alto grau de adequação aos requisitos ISO 9001:2000. Embora a "empresa E" não tenha obtido o percentual máximo nos requisitos comprometimento da direção, foco no cliente, política da qualidade e planejamento, recursos humanos, e produção e fornecimento de serviço, a faixa de pontuação global na qual a organização se encontra demonstra o total atendimento aos itens de avaliação. 
Quadro 30 - Síntese da pontuação obtida pela "empresa E"

\begin{tabular}{|c|c|c|c|}
\hline Itens de Avaliação & $\begin{array}{l}\text { Pontuação } \\
\text { Máxima }\end{array}$ & $\begin{array}{l}\text { Percentual } \\
\text { Obtido }\end{array}$ & $\begin{array}{c}\text { Pontuação } \\
\text { Obtida }\end{array}$ \\
\hline \multicolumn{4}{|l|}{ 1. Sistema de Gestão da Qualidade } \\
\hline 1.1. Requisitos gerais & 150 & $100 \%$ & 150 \\
\hline 1.2. Requisitos de documentação & 150 & $100 \%$ & 150 \\
\hline \multicolumn{4}{|l|}{ 2. Responsabilidade da Direção } \\
\hline $\begin{array}{l}\text { 2.1. Comprometimento da direção, foco no cliente, } \\
\text { política da qualidade e planejamento }\end{array}$ & 100 & $90 \%$ & 90 \\
\hline $\begin{array}{l}\text { 2.2. Responsabilidade e autoridade, representante da } \\
\text { direção, comunicação interna e análise crítica } \\
\text { pela direção }\end{array}$ & 100 & $100 \%$ & 100 \\
\hline \multicolumn{4}{|l|}{ 3. Gestão de Recursos } \\
\hline $\begin{array}{l}\text { 3.1. Provisão de recursos, infra-estrutura e ambiente } \\
\text { de trabalho }\end{array}$ & 70 & $100 \%$ & 70 \\
\hline 3.2. Recursos humanos & 70 & $90 \%$ & 63 \\
\hline \multicolumn{4}{|l|}{ 4. Realização do Produto } \\
\hline $\begin{array}{l}\text { 4.1. Planejamento da realização do produto, e } \\
\text { processos relacionados a clientes }\end{array}$ & 40 & $100 \%$ & 40 \\
\hline 4.2. Projeto e desenvolvimento & 40 & $100 \%$ & 40 \\
\hline $\begin{array}{l}\text { 4.3. Aquisição e controle de dispositivos de medição } \\
\text { e monitoramento }\end{array}$ & 40 & $100 \%$ & 40 \\
\hline 4.4. Produção e fornecimento de serviço & 40 & $90 \%$ & 36 \\
\hline \multicolumn{4}{|l|}{ 5. Medição, Análise e Melhoria } \\
\hline 5.1. Medição e monitoramento & 100 & $100 \%$ & 100 \\
\hline $\begin{array}{l}\text { 5.2. Controle de produto não-conforme, análise de } \\
\text { dados e melhorias }\end{array}$ & 100 & $100 \%$ & 100 \\
\hline Total Geral & 1000 & & 979 \\
\hline
\end{tabular}

\section{Foco no cliente}

Pontos fortes: A organização assegura que os requisitos do cliente são determinados através da análise crítica dos contratos firmados anualmente. As rotinas estabelecidas nos procedimentos e instruções de trabalho contemplam os métodos pertinentes aos requisitos contratuais. Para o monitoramento da satisfação dos clientes, a organização realiza uma pesquisa anual com o propósito de avaliar e aumentar a satisfação dos 
clientes. Além disso, a empresa conta com vários canais de comunicação com o cliente. Todas estas práticas estão devidamente padronizadas nos procedimentos documentados.

\section{Liderança}

Pontos fortes: Para disseminar o compromisso com o sistema de gestão da qualidade, são realizadas reuniões de acompanhamento semanais, para apurar a evolução dos indicadores de desempenho operacionais e também reuniões de acompanhamento mensais para a análise da evolução dos indicadores estratégicos pertinentes ao sistema de gestão da qualidade. Além das reuniões de acompanhamento, a empresa conta com vários canais de comunicação que permitem a disseminação das informações relativas à qualidade. Tais canais incluem jornal interno, intranet, internet, quadro de avisos, etc.

Oportunidades para melhoria: A organização evidencia seu comprometimento com o sistema de gestão da qualidade através da política da qualidade, dos objetivos da qualidade. da condução de análises críticas pela alta direção e da disponibilidade de recursos. Contudo, não foi evidenciado que o atendimento aos requisitos pertinentes são comunicados a todos os colaboradores da organização. Além disso, uma recente pesquisa realizada internamente pela organização evidenciou esta lacuna.

\section{Envolvimento das pessoas}

Pontos fortes: A organização estabeleceu o procedimento "PG 15002" como sistemática para a determinação das competências necessárias, identificação das necessidades de treinamento e conscientização dos colaboradores, bem como para a necessidade de avaliações da eficácia desses treinamentos. Para os colaboradores recém-admitidos, a organização realiza palestras de integração e treinamento interno para entendimento das atividades e cumprimento dos procedimentos operacionais e instruções de trabalho.

Oportunidades para melhoria: Nem todas as pessoas que ocupam cargos operacionais e que foram entrevistadas demonstraram estar conscientes quanto à pertinência e importância de suas atividades e de como elas contribuem para atingir os objetivos da qualidade. 


\section{Abordagem de processo}

Pontos fortes: A identificação, seqüiência e interação dos processos necessários ao sistema de gestão da qualidade e sua aplicação por toda a organização foram evidenciadas no manual da qualidade "MQ 00102". Além disso, a organização assegura que seus processos são monitorados mediante os padrões definidos nos procedimentos operacionais estabelecidos para cada fase do processo.

\section{Abordagem sistêmica para a gestão}

Pontos fortes: A documentação do sistema de gestão da qualidade da organização inclui declarações da política da qualidade, manual da qualidade e outros manuais de gestão, procedimentos documentados, instruções de trabalho, especificações técnicas e registros e procedimentos documentados requeridos. O plano anual de auditorias abrange todos os processos da organização, incluindo os processos de apoio e de realização do produto, o procedimento "PG 12002" sistematiza a emissão e controle das ações corretivas e preventivas.

\section{Melhoria contínua}

Pontos fortes: A melhoria contínua do sistema de gestão da qualidade da organização foi evidenciada mediante a evolução dos indicadores de desempenho pertinentes à gestão da qualidade, a política da qualidade, os registros de ações corretivas e preventivas e também os registros das análises críticas realizadas anualmente pela organização.

\section{Abordagem factual para a tomada de decisão}

Pontos fortes: $\mathrm{A}$ análise de dados é responsabilidade direta dos gerentes e coordenadores e contempla o uso de informações a respeito da satisfação dos clientes, dos índices de conformidade com os requisitos dos produtos, das características e tendências dos processos e das ações preventivas e corretivas. Além dessas informações, a alta direção analisa os resultados de auditorias e registros de análises críticas antes de realizar o planejamento anual. 
Oportunidades para melhoria: Não foi possível evidenciar que a organização identifica a situação do produto quanto aos requisitos de monitoramento e medição. Além disso, não foi evidenciada nenhuma sistemática documentada referente à identificação da situação do produto.

\section{Benefícios mútuos nas relações com os fornecedores}

Pontos fortes: As sistemáticas para aquisição de materiais, equipamentos e serviços, bem como para avaliação e homologação de fornecedores estão devidamente documentadas nos procedimentos "PG 51202", "PG 51302", "PG 52102", "PG 52202 " e "PG 52302". Os registros demonstram clareza nas informações sobre os requisitos de aquisição. Tais sistemáticas proporcionam aos fornecedores transparência e agilidade no processo de aquisição.

\subsection{Resultados Globais}

A pontuação total obtida pelas organizações avaliadas revela o grau de aderência aos requisitos ISO 9001:2000. Assim, com base nas faixas de pontuação apresentadas no Quadro 31 é possível reconhecer o estágio de adequação de cada empresa avaliada.

Quadro 31 - Faixas de pontuação das empresas avaliadas

\begin{tabular}{|c|c|c|c|}
\hline \multicolumn{3}{|c|}{ Faixa } & \multirow{2}{*}{$\begin{array}{l}\text { Empresa/ } \\
\text { Pontuação obtida }\end{array}$} \\
\hline $\mathrm{N}^{\circ}$ & Posição & Pontuação & \\
\hline \multirow{2}{*}{5} & Média & $971-1000$ & "Empresa E" (979) \\
\hline & Baixa & $901-970$ & \\
\hline \multirow{3}{*}{4} & Alta & $831-900$ & 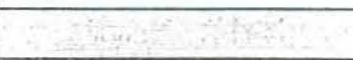 \\
\hline & Média & $761-830$ & $\therefore \quad 9 \quad$ \\
\hline & Baixa & $701-760$ & 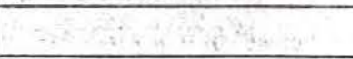 \\
\hline \multirow{3}{*}{3} & Alta & $631-700$ & \\
\hline & Média & $561-630$ & \\
\hline & Baixa & $501-560$ & "Empresa D" (533) \\
\hline \multirow{3}{*}{2} & Alta & $431-500$ & $\begin{array}{l}\text { "Empresa C" (466) } \\
\text { "Empresa B" (433) }\end{array}$ \\
\hline & Média & $361-430$ & $2+8$ \\
\hline & Baixa & $301-360$ & "Empresa A" (336) \\
\hline \multirow{3}{*}{ l } & Alta & $201-300$ & \\
\hline & Média & $101-200$ & \\
\hline & Baixa & $0-100$ & \\
\hline
\end{tabular}


A "empresa A" encontra-se em uma posição baixa na segunda faixa de pontuação. Isto significa que embora seja possível evidenciar o atendimento a certos requisitos, tais como projeto e desenvolvimento, provisão de recursos, infra-estrutura e ambiente de trabalho, ainda existem algumas lacunas importantes no atendimento aos requisitos de documentação e responsabilidade da direção, além da falta de sistematização das atividades relacionadas à gestão dos recursos humanos, medição, análise e melhoria.

As "empresas B e C" também se encontram na segunda faixa de pontuação, porém, ocupam uma posição alta. Isto significa que alguns processos possuem um maior grau de aderência aos requisitos ISO 9001:2000, incluindo provisão de recursos, infraestrutura e ambiente de trabalho, além de atenderem boa parte dos requisitos de realização do produto. Contudo, há lacunas significativas que precisam ser trabalhadas principalmente quanto aos requisitos de documentação e responsabilidade da direção, projeto e desenvolvimento, análise de dados e melhorias.

Com 533 pontos obtidos, a “empresa D” está situada na posição baixa da terceira faixa. Esta faixa revela que, embora existam algumas lacunas importantes no atendimento aos itens de avaliação, tais como projeto e desenvolvimento, requisitos de documentação, além da falta de sistematização de algumas rotinas relacionadas ao controle de produto não-conforme, análise de dados e melhorias, e comprometimento da direção, boa parte dos processos atende aos requisitos ISO 9001:2000, principalmente quanto aos requisitos relacionados à gestão de recursos e realização do produto.

Das empresas avaliadas, apenas a "empresa E" obteve a melhor faixa de pontuação, com 979 pontos. É importante ressaltar que a "empresa E" representa a única organização certificada na norma ISO 9001:2000 que participou do processo de aplicação desta proposta. Assim, o estágio da organização segundo as faixas de pontuação revela que o seu sistema de gestão da qualidade atende totalmente aos itens de avaliação. Entretanto, mesmo com total aderência aos itens de avaliação, foi possível identificar oportunidades para melhoria, conforme relatado na última seção. Neste sentido, a organização pode utilizar o processo de avaliação para buscar a melhoria do sistema, ou seja, a pontuação máxima (1000 pontos). 


\section{CONCLUSÕES}

Neste Capítulo são apresentadas algumas conclusões acerca da concepção e aplicação da proposta, a qual foi desenvolvida a partir de uma revisão de literatura e de uma abordagem prática realizada através de aplicações em empresas reais com o intuito de avaliar as práticas de gestão da qualidade dessas organizações em relação aos requisitos ISO 9001:2000.

O processo de avaliação proposto foi desenvolvido a partir dos referenciais teóricos explorados e citados no Capítulo 3 e adaptados para os objetivos deste trabalho. Neste sentido, pode-se apresentar algumas conclusões acerca do desenvolvimento e da aplicação prática da proposta, levando em consideração os objetivos do trabalho, a forma como foi desenvolvida a proposição do processo de avaliação, assim como a construção do instrumento avaliatório e das constatações realizadas durante a aplicação prática nas empresas. Finalizando o trabalho são apresentadas algumas limitações percebidas durante a aplicação da proposta e também algumas sugestões para trabalhos futuros.

\subsection{Objetivos do trabalho}

Com base nos resultados obtidos através dos relatórios de avaliação, o objetivo principal deste trabalho foi alcançado, visto que o trabalho de campo resultou em uma avaliação das atuais práticas de gestão da qualidade das empresas selecionadas quanto ao estágio de adequação dessas práticas em relação aos requisitos ISO 9001:2000.

O processo de avaliação proposto, tal como está estruturado no Capítulo 3, foi desenvolvido com a finalidade de permitir a condução das atividades de avaliação através de cinco passos seqüenciais, com o uso de um instrumento simplificado para a coleta e análise das informações apuradas, assim como para estabelecer a pontuação pertinente e a determinação do estágio atual de adequação aos requisitos aplicáveis. 


\subsection{Desenvolvimento da proposta}

Através da revisão bibliográfica foi possível identificar alguns modelos que serviram de referencial para o desenvolvimento da proposta. A seqüência lógica de atividades estabelecida na norma NBR ISO 19011 (ISO, 2002a), para o processo de auditorias, permitiu a identificação de etapas cruciais no processo de avaliação. Quanto ao instrumento "Os primeiros Passos para a Excelência", da Fundação para o Prêmio Nacional da Qualidade (2002b), foi possível adequar sua estrutura aos requisitos ISO 9001:2000. Com isso, a sistemática de registro das evidências apuradas, bem como o uso de escalas de alternativas, facilitaram tanto as atividades de coleta e análise de informações como a atividade de pontuação dos aspectos de avaliação. Além disso, o uso de faixas de pontuação, a partir da pontuação global obtida por cada empresa, permitiu a identificação do estágio atual de adequação aos requisitos ISO 9001:2000.

A proposta apresentada neste estudo mostrou-se satisfatória à medida que a aplicação do processo de avaliação nas empresas selecionadas permitiu a identificação de lacunas e a ponderação sobre o estágio atual de adequação aos requisitos ISO 9001:2000 dessas organizações. Cabe ressaltar que o estudo também contribui com a proposição de um processo de avaliação capaz de melhorar continuamente as práticas de gestão avaliadas, podendo também ser adaptado para outros modelos de gestão.

\subsection{Constatações decorrentes da aplicação}

Em relação às empresas avaliadas, foi possível aplicar a proposta em diversas organizações, independente de seu porte ou setor de atuação, tanto em organizações certificadas, com em organizações que, mesmo não sendo certificadas, acabam adotando diversas práticas de gestão da qualidade. Considerando as características inerentes ao tipo de metodologia utilizada na aplicação da proposta é possível apresentar os seguintes aspectos:

as entrevistas permitiram a interação entre o pesquisador e as pessoas representantes das empresas selecionadas;

$>$ através da interação entre o pesquisador e as pessoas entrevistadas foi possível realizar a avaliação seguindo o processo descrito no Capítulo 3; 
$>$ as empresas selecionadas aceitaram a aplicação da proposta com o intuito de identificar o estágio atual de adequação aos requisitos ISO 9001:2000 e melhorar a suas práticas de gestão;

os relatórios de avaliação foram entregues às empresas avaliadas e revelaram os pontos fortes e as oportunidades para melhoria, bem como o atual estágio de adequação dessas organizações em relação aos requisitos ISO 9001:2000;

$>$ as pessoas envolvidas na aplicação prática acompanharam todas as atividades do processo de avaliação sem demonstrar qualquer tipo de resistência;

$>$ a aplicação prática permitiu o aumento do conhecimento das pessoas envolvidas em relação ao processo de avaliação e a aplicabilidade dos requisitos ISO 9001:2000.

\subsection{Limitações acerca da proposta}

Durante a aplicação da proposta foi possível perceber uma certa "valorização" das práticas relacionadas à gestão da qualidade por parte das lideranças das organizações avaliadas. Tal comportamento foi percebido durante as entrevistas, onde o pesquisador, ao questionar sobre os aspectos de avaliação, nem sempre recebia uma resposta coerente com as evidências apuradas, ou seja, o atendimento aos aspectos de avaliação, nem sempre era confirmado através das evidências objetivas, de modo a corroborar a resposta dada pelos entrevistados.

Quanto ao instrumento avaliatório utilizado, foi possível constatar que o fato de o texto referente aos aspectos de avaliação estar escrito no estilo afirmativo, muitas vezes induzia os entrevistados a darem respostas diretas do tipo "sim" e "não". Além disso, a palavra "possui" incluída nos aspectos de avaliação para avaliar principalmente os requisitos de documentação, pode limitar a análise dos documentos pertinentes, pois somente o fato de a organização "possuir" tal documento, pode significar o total atendimento ao aspecto relacionado sem levar em consideração fatores como atualização, aprovação, adequação aos requisitos pertinentes, etc.

Com base no que foi exposto acima, torna-se evidente a necessidade de conhecimentos básicos sobre os requisitos ISO 9001:2000 por parte dos avaliadores durante o processo de avaliação, de modo a evitar que o diagnóstico das práticas de gestão da qualidade segundo os requisitos ISO 9001:2000 seja incoerente com a realidade da empresa. 


\subsection{Sugestões para trabalhos futuros}

Com base no aprendizado proporcionado durante todas as etapas de realização deste trabalho torna-se possível indicar como sugestões e extensão do tema que poderão ser futuramente explorados:

desenvolver estudos sobre como cada requisito normativo se apresenta em diferentes organizações;

$>$ explorar o processo de avaliação como guia para a melhoria de sistemas de gestão;

$>$ desenvolver um processo para avaliar as práticas de gestão da qualidade em redes de operações;

desenvolver um processo para avaliar as práticas de gestão de uma organização em relação a requisitos aplicáveis a outros sistemas de gestão;

desenvolver sistemas informatizados para dar suporte a aplicação da proposta.

Assim, espera-se que este trabalho possa servir de guia para a realização de novos estudos e novas aplicações práticas no âmbito das organizações. contribuindo desta forma, para a gestão da melhoria organizacional. 


\section{REFERÊNCIAS}

BENDELL, T. (2000). The implications of the changes to ISO 9000 for organisational excellence. Measuring Business Excellence; v. 4, n.3.

BROCKA, B.; BROCKA, M. S. (1994). Gerenciamento da qualidade. São Paulo: Makron Books.

BROWN, M. G. (1995). O sistema Baldrige da qualidade, São Paulo: Makron Books.

CAILliBOT, P. F. (2001). ISO 9001:2000 the challenges of the new version. ISO Management Systems, Oct 2001.

CARVALHO de, A. B. M. (2002). A ISO 9001:2000 sem segredos. Banas Qualidade, São Paulo, n. 117, fev. encarte especial.

CORBETT, C. J.; LUCA, A. M.; PAN, J. (2003). Global perspectives on global standards: a 15-economy survey of ISO 9000 and ISO 14000. ISO Management Systems, Jan-Fev.

CURKOVIC, S.; PAGELL M. (1999). A critical examination of the ability of ISO 9000 certification to lead to a competitive advantage. Journal of Quality Management, v. 4, n.1, p. 51-67.

DAVENPORT, T. H. ; PRUSAK, L. (1999). Conhecimento empresarial. Rio de Janeiro: Campos; São Paulo: Publifolha.

DICK, G.P.M. (2000). ISO 9000 certification benefits, reality or myth? The TQM Magazine, v. 12, n. 6, p. 365-371.

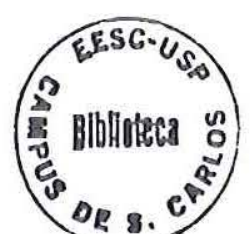


DOUGLAS, A.; COLEMAN, S. ; ODDY, R. (2003). The case for ISO 9000. The TQM Magazine, v. 15, n. 5.

EUROPEAN FOUNDATION FOR QUALITY MANAGEMENT - EFQM (2004). Introdução à excelência.

Disponível em <http://www.efqm.org/downloads/pdf/4230-InEx-Por_v2.pdf > Acesso em 17/05/2004.

FAESARELLA, I. S.; SACOMANO, J. B.; CARPINETTI, L. C .R. (2003). Gestão da qualidade: conceitos e ferramentas. São Carlos, EESC.

FUNDAÇÃO PARA O PRÊMIO NACIONAL DA QUALIDADE - FPNQ, (2000). Primeiros passos para a excelência. Revista Banas Qualidade, n. 97, jun., p. 42-43. (2002a). Critérios de excelência - o estado da arte da gestão para a excelência no desempenho e o aumento da competitividade. São Paulo: FPNQ.

(2002b). Primeiros Passos para a Excelência: critérios para o bom desempenho e diagnóstico da organização. São Paulo: FPNQ.

GARVIN, D. A. (1992). Gerenciando a qualidade: visão estratégica e competitiva. Rio de Janeiro: Qualitymark.

GHOBADIAN, A ; WOO, H. S. (1996). Characteristics, benefits and shortcomings of four major quality awards. International Journal of Quality \& Reliability Management, v. 13, n. 2 , p. $10-44$.

GILL, J ; WHITTLE, S. (1993). Management by panacea: accouting for transience (cyclical nature of management by objectives, organization development and TQM. Journal of Managem Studies, v. 30, n. 2, p. 281-95.

INSTITUTO NACIONAL DE METROLOGIA, NORMALIZAÇÃO E QUALIDADE INDUSTRIAL - INMETRO (2004). Disponível em <http://inmetro.gov.br/gestão9000/dados_estat.asp?Chamador=INMETROCB25> 
Acesso em 26/05/2004.

INTERNATIONAL ORGANIZATION FOR STANDARDIZATION - ISO. (2004).

Disponível em $<\underline{\text { http://wwww.iso.org/iso/en/ISOOnline.frontpage }>}$

Acesso em 03/06/2004.

. (2002a). NBR ISO 19011: Diretrizes para anditorias de sistema de gestão da qualidade e/ou ambiental. Rio de Janeiro: ABNT.

. (2002b). The ISO survey of ISO 9000 and ISO 14001 certificates; twelfth cycle: up to and including 31 December 2002.

Disponível em $<$ http://www.iso.org/iso/en/ISOOnline.frontpage $>$ Acesso em 17/05/2004.

. (2000). NBR ISO 9001:2000. Sistemas de gestão da qualidade - requisitos. Rio de Janeiro: ABNT.

JONES, R.; ARNDT, G.; KUSTIN, R.(1997). ISO 9000 among Australian companies: impact of time and reasons for seeking certification on perceptions of benefits received. International Journal of Quality \& Reliability Management, v. 14, n. 7, p. 650-660.

LEE, T. Y.: LEUNG, H. K. N.; CHAN K. C. C. (1999). Improving quality management on the basis of ISO 9000. The TQM Magazine, v.11, n. 2, p. 88-94.

MAGD, H.; CURRY, A. (2003). ISO 9000 and TQM : are they complementary or contradictory to each other?. The TQM Magazine, v. 15, n.4, p. 244-256.

MARTÍNEZ-LORENTE, A. R.; DEWHURST, F.; DALE, B. G. (1998). Total quality management: origins and evolution of the term. The TQM Magazine, n. 5, p. 378-86.

MEEGAN, S. T.; TAYLOR, W. A. (1997). Factors influencing a successful transition from ISO 9000 to TQM: the influence of understanding and motivation. International Journal of Quality \& Reliability Management, v. 14, n. 2/3, p. 100-17. 
MELLO, C. H. P. et al. (2002). ISO 9001:2000: sistemas de gestão da qualidade para operações de produção e serviços. São Paulo: Atlas.

NASCIMENTO, L.C.; ALVES, N.A. (2001) Os critérios do PNQ e a ISO 9000:2000, Banas Qualidade, São Paulo, p 30-34, n. 13, out.

NATIONAL INSTITUTE OF STANDARS AND TECNOLOGY - NIST (2004).

Criteria for performance excellence.

Disponível em $<$ http://www.quality.nist.gov/PDF_files/2004_Business_Criteria.pdf $>$ Acesso em 21/07/2004.

OTT, R. (1997) Sistemas de gestão da qualidade: ISO 9000 e outros. In:

HARRINGTON, H. J. Gerenciamento total da melhoria contínua. São Paulo: Makron Books.

PALADINI, E.P. (2002). Avaliação estratégica da qualidade. São Paulo: Atlas.

PRANCIC, E. ; TURRIONI, J. B. (2001). O desafio da edição da ISO 9000:2000 em acabar com as críticas a sua adoção. In XXI ENCONTRO NACIONAL DE ENGENHARIA DE PRODUÇÃO - ENEGEP, 2001, Salvador, Anais...CD-ROM.

PUN, K.F.: CHIN. K.S; LAU H. (1999). A self-assessed quality management system based on integration of MBNQA/ISO 9000/ISO 14000, International Journal of Quality \& Reliability Management. vol.16, n. 6, p. 606-629.

RITCHIE, L. ; DALE, B. G. (2000) Self-assessment using the business excellence model: a study of practice and process. International Journal of Production Economics, n. 66 p. $241-54$.

RODRIGUES, M. V. (1999). Processo de melhoria nas organizações brasileiras. Rio de Janeiro: Qualitymark.

ROESCH, S.M.A (1999). Projetos de estágio e de pesquisa em administração. São Paulo: Atlas. 
ROTHERY, B. (1993). ISO 9000. São Paulo: Makron Books.

RUTKOWSKI, J. (2001). Os prèmios da qualidade como instrumento de diagnóstico e melhoria do desempenho de empresas. In: XXII ENCONTRO NACIONAL DE ENGENHARIA DE PRODUÇÃO - ENEGEP, 2002, Curitiba, Anais... CD-ROM.

SEDDON, J. (1997). Ten arguments against ISO 9000. Managing Service Quality, v. 7, n. 4 , p. $162-168$.

SINGELS, J.; RUËL, G. ; WATER, H. V. (2001). ISO 9000 series: certification and performance. International Journal of Quality \& Reliability Management, v. 18, n. 1, p. $62-75$.

SLACK, N. et al. (1997). Administração da produção. São Paulo: Atlas.

STEVENSON, T. H.; BARNES, F. C. (2001). Fourteen years of ISO 9000: impact, criticisms, costs, and benefits. Business Horizons, may-jun.

TAVARES JUNIOR, J. M. (2001). Metodologia para avaliação do sistema integrado de gestão: ambiental, da qualidade e da saúde e segurança. Tese (Doutorado em Engenharia de Produção) Universidade Federal de Santa Catarina, Florianópolis, 2001. Disponível em: $<$ http://teses.eps.ufsc.br/Resumo.asp?2664>. Acesso em: 12 mai.2003.

THIOLLENT, M. (1992). Metodologia da pesquisa-ação. Cortez / Autores Associados, São Paulo.

TOLEDO, J. C. (1997). Gestão da qualidade na agroindústria. In: Gestão agroindustrial: GEPAI - Grupo de Estudos e Pesquisas Agroindustriais. São Paulo: Atlas.

TSIM, Y.C.; YEUNG, V.W.S.; LEUNG, E.T.C. (2002). An adaptation to ISO 9001:2000 for certified organisations. Managerial Auditing Journal, 17/5, p. 245-50. 
TUMMALA, V.M.R; TANG, C.L. (1996). Strategic quality management, Malcolm Baldrige and e European quality awards and ISO 9000 certification: core concepts and comparative analysis. International Journal of Quality \& Reliability Management, v. 13 , n. 4 , p. $8-38$.

WALTON, M. (1989). O método Deming de administração. Rio de Janeiro: Marques Saraiva.

WOOD JÚNIOR, T. ; URDAN, F. T. (1994). Gerenciamento da qualidade total: uma revisão crítica. Revista de Administração de Empresas. São Paulo, v.34, n. 6, p. 46-59.

YUNG, W.K.C. (1997). The values of TQM in the revised ISO 9000 quality system, International Journal of Operations \& Production Management. vol. 17, n. 2, p. 221230. 